\title{
Hepatic and non-hepatic vitamin K-dependent reactions
}

Citation for published version (APA):

de Boer-van den Berg, M. A. G. (1987). Hepatic and non-hepatic vitamin K-dependent reactions. [Doctoral Thesis, Maastricht University]. Rijksuniversiteit Limburg. https://doi.org/10.26481/dis.19870313mb

Document status and date:

Published: 01/01/1987

DOI:

10.26481/dis.19870313mb

Document Version:

Publisher's PDF, also known as Version of record

\section{Please check the document version of this publication:}

- A submitted manuscript is the version of the article upon submission and before peer-review. There can be important differences between the submitted version and the official published version of record.

People interested in the research are advised to contact the author for the final version of the publication, or visit the DOI to the publisher's website.

- The final author version and the galley proof are versions of the publication after peer review.

- The final published version features the final layout of the paper including the volume, issue and page numbers.

Link to publication

\footnotetext{
General rights rights.

- You may freely distribute the URL identifying the publication in the public portal. please follow below link for the End User Agreement:

www.umlib.nl/taverne-license

Take down policy

If you believe that this document breaches copyright please contact us at:

repository@maastrichtuniversity.nl

providing details and we will investigate your claim.
}

Copyright and moral rights for the publications made accessible in the public portal are retained by the authors and/or other copyright owners and it is a condition of accessing publications that users recognise and abide by the legal requirements associated with these

- Users may download and print one copy of any publication from the public portal for the purpose of private study or research.

- You may not further distribute the material or use it for any profit-making activity or commercial gain

If the publication is distributed under the terms of Article $25 \mathrm{fa}$ of the Dutch Copyright Act, indicated by the "Taverne" license above, 


\section{Hepatic and non-hepatic vitamin $\mathrm{K}$-dependent reactions}





\section{Hepatic and non-hepatic vitamin K-dependent reactions}

\section{PROEFSCHRIFT}

ter verkrijging van de graad van doctor in de geneeskunde aan de Rijksuniversiteit Limburg te Maastricht, op gezag van de Rector Magnificus Prof. Dr. F.I.M. Bonke, volgens besluit van het College van Dekanen, in het openbaar te verdedigen in de aula van de universiteit op vrijdag 13 maart 1987, des namiddags te vier uur

door

Maria Anna Gerardina de Boer-van den Berg geboren te Amsterdam 
Promotor : Prof. Dr. H.C. Hemker

Co-promotor : Dr. C. Vermeer

Referenten : Prof. Dr. R. Azerad

Dr. H.H.W. Thijssen

ledereen, die op welke wijze dan ook aan de totstandkoming van dit proefschrift heeft bijgedragen, wil ik daarvoor hartelijk bedanken. In het bijzonder ben ik Jurjen, mijn familie en vrienden erkentelijk voor hun nimmer aflatende steun en begrip.

Ontwerp omslag: J.E.G. de Boer

Druk: Krips Repro Meppel 
"Heel het leven bestaat uft lets achterlaten

en een sprong woorwarts maken nar lets nleuws"

Paul Pruijser

aan mifn ouders

aan Jurjen

voor alle gemiste uren 


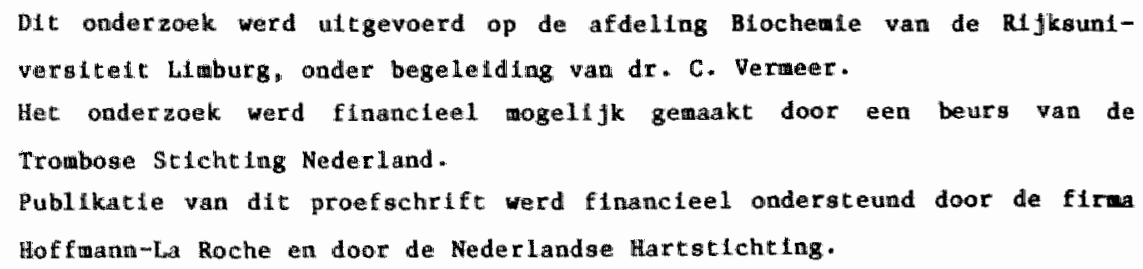


CONTENTS

Chapter 2 Vitamin $k$-dependent carboxylase in skin

J. Invest. Dermatol $87: 377-380,1986$

Chapter 3 The in vivo effect of acenocoumarol, phemprocoumon and warfarin on vitamin $K$ epoxide reductase and vitamin $\mathrm{K}$-dependent carboxylase in various tissues of the rat Biochim * Biophys. Acta 884: 150-157, 1986

Chapter 4 Decarboxylated bone Gla-protein as a substrate for hepatic vitamin K-dependent carboxylase

FEBS Lett. 165:16-20, 1984

Chapter 5 Discovery of a 4-carboxyglutamic acid-contalning proteln in human spermatozoa FEBS Lett. 190: 137-141, 1985

Chapter 6 Isoenzymes of vitanin K-dependent carboxylase Biochim. Biophys. Acta 830: 105-1.08, 1985

Chapter 7 Vitamin $k$-dependent carboxylase: the carboxy lation of exogenous substrates In different systems

Biochim. Blophys. Acta 831:94-98, 1985

Chapter 8 Direct measurement of vitamin K-dependent enzymes in warious isolated and cultured tumor and non-tumor cells Molec. Cell Biochem. in the press 

Chapter 9 Vltamin K-dependent enzymes in cultured cells from thum arterial and venous vesse1 wall submited for publucation

Chapter 10 Some characteristics of vitamin $k$-dependent carboxylase in human tissues gubnitued for publication

Chapter 11 "The in vivo effects of 4-hydroxycoumarin derivatives on huan hepatic and non-hepatic vitumin $K$-dependent enzymes submitted for publication

Chapter 12 Summary and general discussion

Samenvating 
Vitamin $\mathrm{K}$ was discovered by Henrik Dam in 1935, when he studied the effects of a cholesterol-free diet on chickens (1). He observed that the animals had developed hemorrhages and that their blood exhibited a prolonged coagulation time. These hemostatic defects turned out to be related to the deficiency of a fat soluble vitamin, which was called Kaagulations-witamin (coagulation vitamin) or shortly vitamin $K$. The bleeding symptoms prowoked by vitamin $k$-deficiency were similar to those described for a hemorrhagic desease in cattle (2). These hemorrhages were found to be caused by feeding the animals inproperly cured sweet clover hay. The active compound in the clover was identified as 3,3 methylene-bis (4-hydraxycoumarin) (3), which is present in a chemlcally bound inactive form in the fresh plants, but which may be liberated during the curing of the clover. In its free form the 4-hydroxycoumarin derivative acts as an antagonist of vitamin $K$. In the following years numerous coumarin-derivatives have been synthesized and used for the treatment of patients to antagonize undesired blood coagulation during thrombogenlc episodes. Some of them are also used in the form of rodentlcides. The structures of vitamin $K$ and some frequently used coumarin-derlvatives are shown in $\mathrm{fig} .1$.

\section{DISCOVERY OF 4-CARBOXYGLUTAMIC ACID}

After the discovery that vitamin $K$ was Inwolved in blood comgulation, various hypotheses about the action of vitamin $K$ were postulated (4). $A$ 


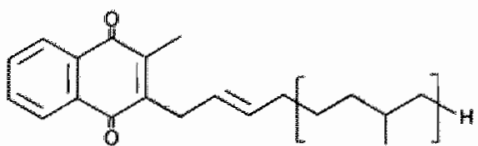

vitamin $k_{1}$ or plylloquinone

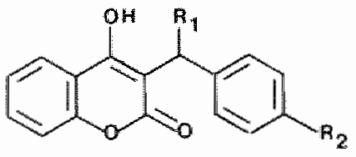

4-hydroxycoumarin derivatives:

$\begin{array}{ll}\mathrm{R}_{1} & \mathrm{R}_{2} \\ \mathrm{CH}_{2} \mathrm{COCH}_{3} & \mathrm{NO}_{2} \\ \mathrm{CH}_{2} \mathrm{CH}_{3} & \mathrm{H} \\ \mathrm{CH}_{2} \mathrm{COCH}_{3} & \mathrm{H}\end{array}$

Pig. 1.

Stmatures of vitamin $K_{1}$ and some 4-hydroxycoumarin derivatives

real step forward was the postulation of Hemker et all. (5) that blood from patients receiving oral anticoagulant therapy contains a mixture of normal and abnormal prothrombin. The abnormal prothrombin was called "PIVKA" (protein induced by vitamin $K$ antagonists) and it was regarded as a precursor of prothrombin. This hypothesis was strenghtened by the demonstration of a protein antigenically similar to prothrombin but lacking blologlcal activity in the plasma of patients recelving counarin-therapy $(6,7)$. The abnormal prothrombin seened to be very similar to the normal one but appeared to lack the ablity to bind calcium ions $(8,9)$. In 1974, it was reported independenty by the groups of Stenflo (10), Nelsestuen (11), and Magnusson (12), that the $\mathrm{Ca}^{2+}$-binding sites in normal prothrombin were Formed by an abnormal anino-acid, the 4-carboxyglutanic acid or $\gamma$-carboxyglutamic acld (Gla, for structure see flg. 2). Since this nodified amino-acid ls absent in PIVKA, it was concluded that vitamin $k$ is involved in the postranslational carboxylation of glutamic acid residues in a prothrombin precursor protein. Gla-residues were also demonstrated in the coagulation factors VII, IX and $X(13)$ and more recenty in protein $C$ (14), and protein $S(15)$, which are also involved in blood coagulation and proteln $z(16)$, which function is unknown. Presently we know that vitamin 


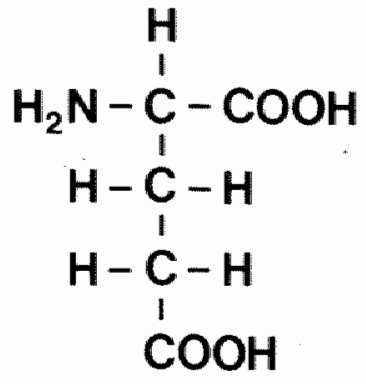

Glu

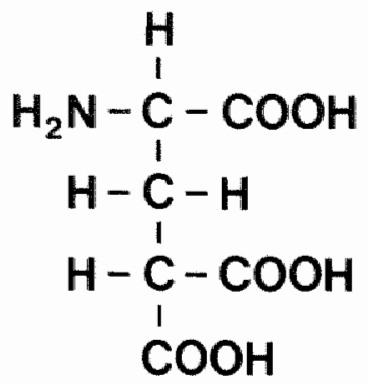

Gla

Pig. 2.

Structural formulae of glutamic acid (GLu) and 4-cambaxygtutamic acid (Gla)

$\mathrm{K}$-dependent carboxylation is not uniquely restricted to proteins involved in blood coagulation. The formation of Gla-residues is a modification, which is undergone by numerous other proteins, synthesized in various tissues $(17,18)$.

\section{SYNTHESIS OF VITAMIN K-DEPENDENT PROTEINS}

All vitamin $K$-dependent protelns discovered up to now belong to the sa-called secretory-proteins. These proteins are excreted tnto the extraceliular fluid or to the outer cell membrane after thell maturation has been completed. The mechanism by which they are syntheslzed has been clarified by Blobel et a1. (19) and Meijer et al. $(20,21)$, while the groups of MacGilivray and Davie have studied in particular the blosymthesis of prothrombin $(22,23,24)$ The basic concept in thelr biosynthesis is the presence of a hydrophobic leader sequence, consisting of a signal presegment ( $18-34$ residues) and a basic pro-segment (5-9 residues) at the N-terminal side of the growing peptide chain. Once 1 t has been synthesized and emerged from the ribosome the signal sequence will be recognized and bound by the signal recognition particle (SR.P) in the cytoplasm, causing a s.top of any further polypeptide chain elongation. A second protein involved 
In this process is located on the rough endoplasmic reticulum menbrane. This so-called "docking proteln" is able to recognize the sRP-ribosome complex and to medite its binding to the endoplasmic reticulum, resulting in a reluttation of protein symthesis. The hydrophobic signal sequence rapidly penetrates into the phospholipid membrane, thus facilitating the transpot of the growing protein through the nembrane to the luminal side of the endoplaside tubuli. Here are located the enzymes required for postranslational modiflcations, such as glycosylation, hydroxylation and vitamln $K$-dependent carboxylation. Obviously not all secretory proteins undergo all posstble modifications and the mechanism, responsible for the selection of carboxylatable Glu-residues is still a matter of research.

\section{PARTIAL PURIFICATLON OF VITAMIN $K$-DEPENDENT CARBOXYLASE}

Since the discovery of vitamin $K$-dependent carboxylase activity many attempts have been undertaken to purify the enzyme. The enzyme acts as a typical integral membrane protein. Relatively high concentrations of detergent (Triton $x-100$, CHAPS, Lubrol) are required and even after solubilization the enzyme remains assoclated with phospholipids and contaminating proteins. Further desintegration of these structures inevitably leads to an almost complete loss of carboxylase activity (4).

Canfield et al. (25) and Wallin and Suttie (26) developed procedures for the specific extraction of a number of rat liver microsomal membrane proteins, using various detergents and chaotropic agents. By this procedure the specific enzymatic activity could be increased about 100-fold, but this increase was manly due to the elimination of an inhibitor of the vitamin $k$ dependent carboxylation rather than to the removal of a substantial amount of contaminating protelns.

Another attempt was done by O1son et al. (27), who tried to purtify on a heparin affinity colum the carboxylase-bound prothrombin precursors in a 11 ver homogenate from warfarin treated rats. The enzyme/substrate complexes could be bound and subsequently eluted with a recovery of about $10 \%$. The total purification was 100 -fold but it is not sure whether this is due to the removal of an inhibitor as reported above or to the elimination of contaminating proteins. 
A slightly different approach was followed by De Metz et al. (28) who first determined the identity of the accumulated substrate for carboxylase in the livers of warfarin-treated cows. It turned out that about $60 \%$ of the carboxylatable material consists of factor $x$ precursors wherease only $25 \%$ could be identified as prothrombin precurors. Consequenty purifled antibodies against normal bovine factor $X$ were covalently ilnked to Sepharose and used for the extraction of enzyme/substrate complexes from detergent treated microsomes. Because vitamin $\mathbb{K}$-dependent carboxylase is firimly bound to its endogenous substrate, the binding of factor X-precursor to the insolubilized antibodies resulted in the specific extraction of enzyme/substrate complexes. By this method, part of the carboxylase activity could be bound to the sepharose beads. After washing away the non bound material, a preparation resulted which was designated as solid-phase carboxylase and resulted in a 50-100 fold purification of the enzyme. A schematic representation of solid-phase carboxylase is given in $\mathrm{fig}^{\text {. }} 3$.

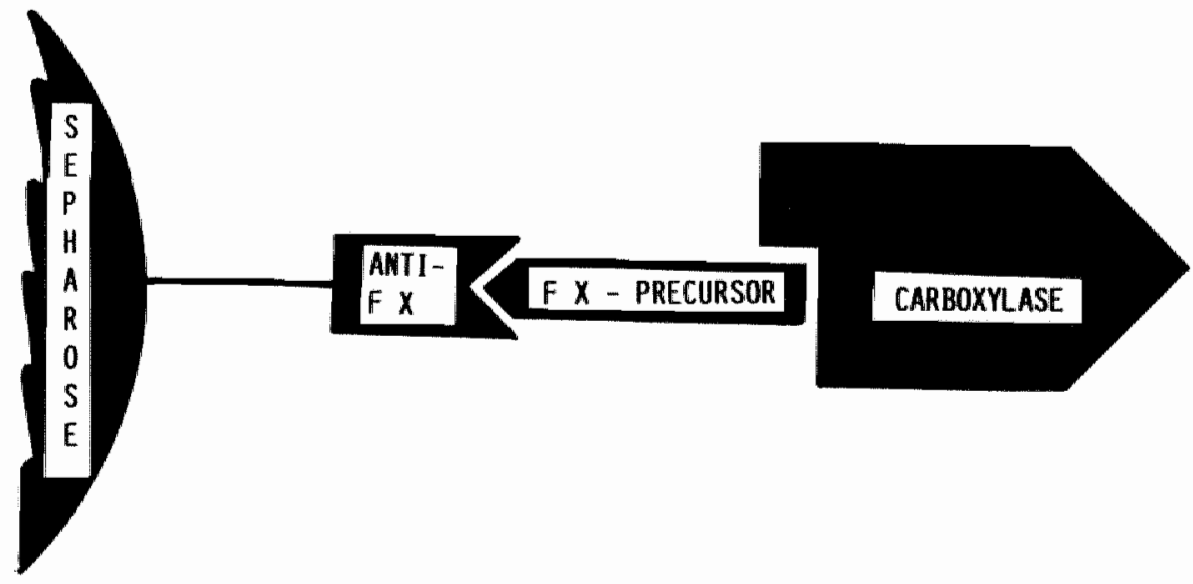

Fig. 3 .

Schematic representation of solid-phare aarboxylare 
Solid-phase carboxylage is able to incorporate ${ }^{14} \mathrm{CO}_{2}$ into endogenous substrates as well as in F L E E L. Later an alson et al. (27) prepared in a similar way a solid-phase carboxylase from rat liver using sepharosebound antibodies against rat prothrombin. Conventional methods for the breakage of the antigen-antibody interaction failed to resolubilize the carboxylase enzyme, because the carboxylation activity was irrewersibly $103 t(29)$.

Recently Girardot (30) has clalmed a 400 fold purification of the carboxylation enzyme from the hepatic microsomal fraction from warfarin rreated rats. The vitamin $K$ dependent enzyme was solubilized with the detergent (CHAPS) and further purified by low-pressure chromatography on lon exchange and size exclusion columins. The final enzyme preparation still contalned an endogenous substrate for carboxylase but showed no reductase activity (see Vitamin $k$ cycle) anymore. Its mollecular weight was decermined to be lower than $350000 \mathrm{D}$. This is the smallest size obtained for the active enzyme complex thus far. Unfortunately this purification procedure has not yet been conflrmed by other laboratories.

\section{VITAMIN K DEPENDENT CARBOXYLATION IN VITRO}

In 1973, Suttie demonstrated an accumulation of coagulation factor precursors in rat liver induced by warfarin (31). In 1975, Esmon et al. found that these precursors could be carboxylated in a cell-free system, prowlded that the reaction mixtures were supplemented with vitamin $K$ and $\mathrm{NaH}^{14} \mathrm{CO}_{3}$ (32). Under these conditions, ${ }^{1 / 4} \mathrm{CO}_{2}$ was incorporated into the endogenous substrate proteins which could subsequently be separated from the bulk of bicarbonate by trichloroacetic acid preclpitation. So, both the w tham $K$-dependent carboxylase enzyme complex and the corresponding endogeous substrate had been found In the same microsomal fraction. Since then, the vitamin $k$-dependent reaction has been studied most extensively in liver microsonal preparations from vitamin $k$-defliclent or warfarin-treated rats $(33,34)$ and from warfarin-treated cows (35). Its main characteristics are sumarlized in table 1 .

Although the use of the carboxylase preparations mentioned above had several advantages (e.g. the correct substrate is complexed to carboxylase in such a way that it is readily carboxylated upon adding vitamin $k$ ) the 
Table 1

Properties af vitamin $K$-dependent carboxylase

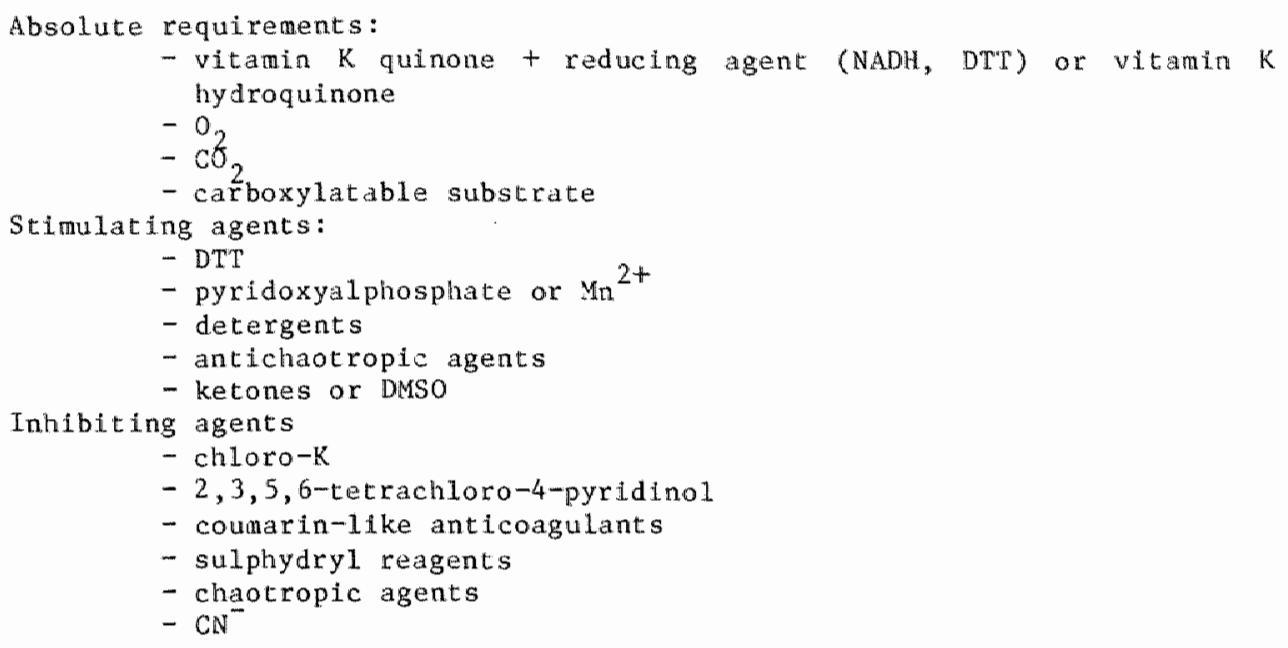

Abbreviations: DTT, dithiothreftol; DMSO, dimethylsulphoxide; chloro-K, 2-chloro-3-phyty1-, 1,3-naphthoquinone.

drawbacks are also obvious. During attempts to purify carboxylase, for instance, the substrate may be lost, which inevitably will lead to the loss of enzyme activity. A second drawback is the fact that klnetic studies may require a substrate present in varying and well-detined atnounts. Therefore also exogenous substrates have been developed. In the flrst place synthetfc substrates have been made $(36,37)$, which all resemble a short Gla-containing amino acid sequence in one of the coagulation factors, but in which Gla has been replaced by Glu. An example of these substrates is Phe-Leu-Glu-Glu-Leu (F L E E L) which shows sequence homology with bovine factor VII and protein C (38). When offered to the carboxylating system, these synthetic pentapeptides were all readily carboxylated, a1though their $\mathrm{Km}$ values were found to be rather $\mathrm{hlgh}(2-10 \mathrm{mM})$. Another synthetic substrate, a tripeptide linked to menadione, has been reported to have a km of about $50 \mu \mathrm{M}$ (39). In higher concentrations this substrate and its analogues appeared to be potent inhibitors of the carboxylation. Another type of exogenous substrates is formed by the proteolytic split products 
derived from PIVkA"s. One of them is fragment Su, derived from descarboxyprothrombir and conslsting of the amino acid residues 13-29 (40). Its Km value 1 about $2 \mu$. Although the bound endogenous proteins are suggested to be carboxylated nearly completely (41) the pentapeptides are thought to be carboxylated for less than $1 \%$. Moreover, only the first Gla-residue has been found to be carboxylated $(42,43)$. The presence of the earlier mentioned leader sequence may be essential for the binding and hence for the effictent carboxylation of the proteins. This idea is supported by the fact that intracellular prothrombin precursors appear to contain a basic prosegment (44). A competitive inhibitor with regard to peptide substrates has been prepared by Gaudry et al. (45). Th1s pentapeptide Phe-Leu-1threo-4-methyl Glu-GIu-Leu exhiblted a Ki of about 65 uM in the carboxylation of $F$ L E E L. Another competitive inhibitor, the peptide Boc-4-methylene Glu-Glu-Va1, with a Ki of about $50 \mu^{M}$ was synthesized by the group of Azerad (46).

In the carboxylation raction the $\mathrm{Km}$ values for $\mathrm{CO}_{2}$ has been estimated to be $0.2-0.4 \mathrm{mM}(47)$ whle the $\mathrm{Km}$ values for $\mathrm{O}_{2}$ ranged between $10-1.5 \mu^{\mathrm{M}}$ in intact microsomes (48) and $45 \mu \mathrm{M}$ in detergent solubllized microsomes (49). The Kin value for $\mathrm{KH}_{2}$ is not known, in most studies $50-500 \mathrm{MM} \mathrm{KH}_{2}$ is used and this quantity does not seem to be rate limiting.

\section{VITAMIN K CYCLE}

In the liver three metabolites of vitamin $K$ have been identified: witamin $K$ qutnone $(K)$, vitamin $K$ hydroquinone $\left(K_{2} H_{2}\right)$ and vitamiln $K 2,3$ epoxide (KO). Calculations based on the dally requirement for vitamin $k$ relative to the formation of Gla, as measured by lts excretion, show that each molecule of the vitanin must be recycled several thousand times before it 1 s metabolized further and excreted (50). Therefore it has been proposed by several groups $(50,4)$ that the 3 forms of vitamin $K$ are interconverted Into each other in a cyclic way as is depicted in fig. 4. In step $1, \mathrm{KH}_{2}$, the active cofactor in carboxylation, is converted in Ko by the vitamin $K$ epoxidase (51). This enzyme may be linked to or identical with the carboxylase. This hypothesis is strengthened by the observation that increasing the concentration of a peptide substrate, which results in an increase in the number of carboxylation events, also leads to an increase 


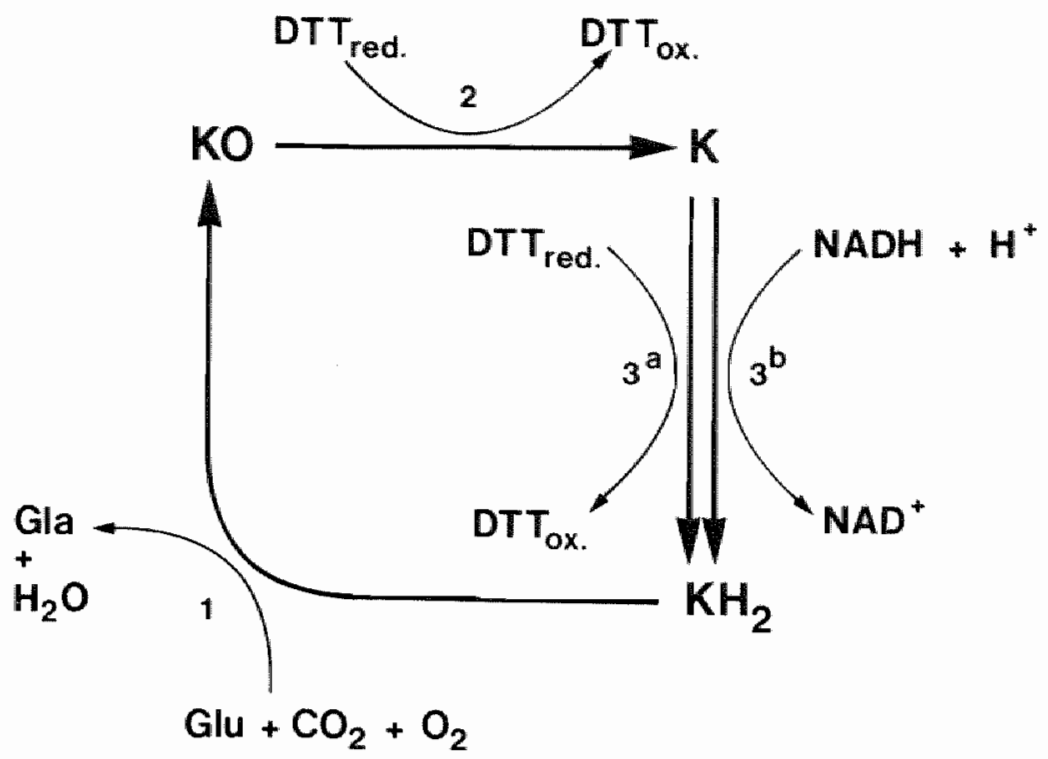

Fig. 4 .

Schematic representation of the vitamin $k$ cycte; for abbreviations gee text

In epoxidase activity (52). It is generally belleved now that the oxidation of $\mathrm{KH}_{2}$ provides the energy required for the carboxylation of glutanic acid residues (34). In step $2, \mathrm{KO}$ is reduced to $\mathrm{K}$ by vitamin $\mathrm{ko}$ reductase. In vitro the reducing equivalents required for this reaction are provided by dithiothreitol (DTP) but its physiological counterpart has not yet been discovered. From recent data $(53,54,55)$ it has been suggested that a free sulphydryl group on the ko reductase attacks the epoxide ring in $k 0$, resulting in a thioether adduct. The next step would be the formation of a 3-hydroxy-vitamin k-enolate, Including the reformation of the disulfide form of the enzyme. The quinone form, $K$, would be subsequently formed by elimination of $\mathrm{H}_{2} \mathrm{O}$ from the $3-\mathrm{hydroxy}-\mathrm{K}$ intermediate. This intermediate has been demonstrated to be present in microsomes from warfarin-resistant rats (56). Step 2 is extremely sensitive to coumarin derivatives $(57,58)$. The close structural simllarity between the postulated enolate form of hydroxyvitamin $K$ and 4-hydroxy-coumarlns might be an explanation for the coumarin induced inlubition $(54,56,59)$. In step 3 , witam $K$ can be reduced 
to $\mathrm{KH}_{2}$ by several posstble enzymes, one driven by DTT and several by NADH. The NADH-dependent DT-dlaphorase vas purtfled from rat liver by wallin et a1. (60). It was found that DT-diaphorase, although in majority cytosolic, 16 also present in microsomes. DT-diaphorase can be inhibited by relatively high concentrations of warfarin (50). Hore recently it was shown that only $45 \%$ of the $\mathbb{N A D}(\mathbb{P}) H$ dependent $K$ reductase activity in Triton $X-100$ solubilized red liver nderosones could be neutralized by antibodies against pure pr-dlaphorase. The remaining NADH-dependent $K$ reductase activity appeared to be warfarin-insensitive. It was assumed that the unidentified NADHdependent dehydrogenase(s) are responsible for the enhanced coagulation factor synthesls, triggered by high concentrations of vitamin $k$ in the presence of coumarin drugs $(62,63,64)$. The existence of a warfarin-insenstive NADH stimulated $K$ reductase was also found by Roncaglioni et all. (65). A DTi-dependent $K$ reductase was identified by Fasco and Principe (66). This enzyme was reported to be very sensituve to warfarin (58). From the present data it is not clear whether both the DTT-dependent $k 0$ and $k$ reductase activitles are catalyzed by the same proteln or by two different ones $(67,68,69)$.

\section{POSTULATED MECHANISMS OF THE VITAMIN K-DEPENDENT CARBOXYLATION REACTION}

When Glu residues are converted into Gla-residues, a proton from the fourth c-atom in Glu must be abstracted and replaced by a carbondioxide group. Originaly, two possibilities for vitamin $K$ action in this process were proposed: 1) as a $\mathrm{CO}_{2}$-carrier and 2) as a cofactor utilized to labllize the abstractable hydrogen at the 4-position $(4,70)$. Friedman et al. (71) have shown that the cleavage of the 4-carbonyl-hydrogen bond is $\mathrm{KH}_{2}-$ and $\mathrm{O}_{2}$-dependent, but independent on $\mathrm{CO}_{2}$ concentrations. From these observations it has been concluded that vitamin $K$ is involved in the hydrogen abstraction.

Dubols et al. (72) and Decottignies-Le Marechal et al. (73) demonstrated that the pro S-hydrogen at the 4-position of the Glu-residue is eliminated prior to carboxylation. These data afford a direct proof for a Glu-site specificity. However, these data do not establish whether a radical-mediated or a ion-mediated mechanism is involved in the carboxylation process. McTigue et al. (74) have recently shown a $\mathrm{KH}_{2}^{-}$and 
$\mathrm{O}_{2}$-dependent ${ }^{3} \mathrm{H}$ incorporation from tritiated water. This result would favour the hypothesis of an ion-mediated mechanism. The role of vitamin $k$ would be the abstraction of the 4-carbonyl-hydrogen as a proton, leaving a carbanion which can react with $\mathrm{CO}_{2}$ to form 4-carboxyglutamic acid.

Some other theories include the formation of radicals wia $\mathrm{KH}_{2}$. Friedman et al. (71) and Larson et al. (75) assumed the formation of a 4-carbonylradical and a wtamin $\mathrm{K}$ radical, while the 4-carbonyl hydrogen is released, followed by the addition of the carbonyl group. De Metz et al. (76) proposed a concerted reaction mechanism via which the proton abstraction, the $\mathrm{CO}_{2}$ addition and the $\mathrm{kO}$ formation all accur by a single electron sheft after the reaction components have been properly aligned on carboxylase.

Current ideas of the carboxylation mechanism stress its relationship to the $k$ epoxidase activity. It is not clear how epoxide formation and 4-hydrogen abstraction are coupled but it could be by an oxygenated intermediate of $\mathrm{KH}_{2}$ in the form of $\mathrm{KHOOH}(70)$. Until now, there is no direct proof for the formation of such an intermediate, however.

Obviously, the investigation concerning the carboxylation mechantsm are hampered by the fact that the enzyme system has not yet been cormpletely purified.

\section{NON-HEPATIC VITAMIN K-DEPENDENT CARBOXYLASE}

It has been assumed for many years that vitamin $K$-dependent carboxylase was only involved in the synthesis of the coagulation ftactors II, VIL, IX and $X$ in the liver. However, Vitamin $k$ was demonstrated to be present not only in liver, but in many other tissues was well $(77,78)$. The onlly known function of vitamin $K$ is its cofactor role in a carboxylation reaction. Lt may not be surprising, therefore, that vitamin k-dependent carboxylase activity can also be demonstrated in various non-hepatc tissues. In 1976 Hauschka et a1. (79) demonstrated vitamin K-dependent carboxylase activity in kidney microsomes. The activity appeared to be localized in the tubular cells (80). Microsomes from embryanic chicken bone also showed vitamin $\mathbb{K}$-dependent carboxylase activity towards synthet lo substrates and an endogenous bone-gla-protein precursor (81). The synthesis of the latter appeared to be inhibited by warfarin ( 82 ). Bone carboxylase is thought to be present in the asteoblast (83). Vitamin $K$-dependent carboxylase activity 
was also detected in alerosomal preparations from lung $(84,85,86)$, spleen $(85,86)$, pancrease $(85,87)$ and testis $(85)$ from nomal and warfarth-treated antmals, and from arteries, cartilage, thymus, thyroid and uterus from a calf, treated with high doses of warfarin. In all tissues mentioned, vermeer et al. (85) observed an increase. In the amount of endogenous substrate after warfarin treatment. Buchtal et a1. (87) reported the presence of vitamin $K$ dependent carboxylase in microsomal preparations from several rat and murine tumors, 1.e. 1 ymphoma, mammary gland, and melanoma. Recently, vitamin K-dependent carboxylase activity has been reported in rabblt $V_{2}$ carclnoma (88). Moreover, the enzymatic activity was also demonstrated in fibroblasts (89).

\section{IDENTIFICATION OF GLA-CONTAINING PROTEINS}

Except for the coagulation factors $I I, V I I, I X$ and $X$, blood plasma contains three more clrculating Gla-containing proteins, the proteins $\mathrm{C}, \mathrm{S}$ and $Z$. Protein $C$, synthesized in the liver, is a glycoprotein, composed of 2 chains, the molecullar weight of which is $41000 \mathrm{D}$ and $21000 \mathrm{D}$ respectively (14). It contains 11 Gla-residues on the $\mathrm{NH}_{2}$-terminal side in the light chain $(90)$. Like the coagulation factors, protein $c$ occurs in plasma in a zymogen form and can be activated into a serine protease by proteolysis with thrombin (91). The function of the activated protein $c$ seems to be the Inactivation of activated factor $V$ and hence 1 it is involved in one of te control mechanisms which limit the coagulation process whenever it has started (92). The activity of activated protetn $C$ is enhanced by the presence of protein 5 . The latter is a glycoprotein consisting of a single polypeptide chain with a molecular weight of about 65000 D and containing 9 Gla-residwes (93). Protein $S$ has been reported to be synthesized by endothella 1 cells (94). Proteln $Z$ is also a single-chain glycoprotein with a molecular weight of approxidately $50000 \mathrm{D}$, contalning 13 Gla residues per molecule, but its function and its place of synthesis are not yet clear (90). A considerable sequence homology has been found between all the Gla-contalning proteins occuring in blood plasma (90). Although in vitro they rapidy bind to insoluble barlum and calcium salts, in vivo they exclusively accur dissolved in plasma. In the presence of calcium ions, 
these proteins have a high affinity towards negatively charged phospholipid surfaces, the binding to which highly stimulated thelr enzymatic activity (95).

As early as in 1976, Hauschka et all (79) reported the presenca of a membrane-bound Gla-containing protein in the kidney. The protein was not further characterized but it may be similar or related to the Gla-containing protein found in calcified renal stones (96). This protein, which is extremely acidic, has a molecular weight of 17000 D and contains about 7 Gla-residues per molecule. It does not seem to be related with any of the plasma-Gla-proteins (82). From human urine a Gla-containing proteln has been isolated (97). This protein has been reported to prevent crystal. growth of calcium oxalate.

Osteocalcin is a Gla-containing protein found in bone (98). It 1s among the six most abundant proteins in man and it comprises over $25 \%$ of the non-collagenous proteins in bone. Human-osteocalcin contains 49 aminoacid residues, among which are three Gla residues (99). The exact function of asteocalcin is not known, but it may play a role in bone development. When coumarin derivatives are administered to women during the first crimester of pregnancy the so-called "fetall warfartin syndrome" (chondrodysplasta punctata) can occur (100). The syndrome is characterlsed by bone abcormalities in the developing fetus. These are caused by the excessive and irregular precipitation of calcium phosphate in the rapidly growing parts of the bone (101). In the calcified areas the growth is stopped in an irreversible way. In vitro studies have demonstrated chat osteocalicin has a very high affinity for hydroxylapatite. In witro, low concentrations of osteocalcit are able to efficiently stop the growth of calclum phosphate crystals from supersaturated solutions $(98,102)$. A second Gla-containtag protein, which is different from osteocalcin, has also been isolated (103). It is called natrix-Gla-protela, its molecular weight is about 15000 D and it contalins 5-6 Gla-residues per molecule.

In the calcified matrix of atherosclerotic human aorta a Gla-containing protein has been reported to be present $(104,105)$. This proteln was originally called atherocalcin and reported to have a molecular weight of about $80000 \mathrm{D}(104)$. Later on, it turned out that the reported molecular weight should be ascribed to a protein complex also contalning albumin and osteocalcin (105). A non-complexed Gla-containing protein, disstimilar to 
osteocalcin, was isolated frow the calcified atherosclerotic plaques. Its molecular weight was estinated to be 6000-10000 D $(105,106)$.

other Gla-containing proteins have been found in dentin (107), in calcifled skin noduli (108) and in corals (109). The biological function of these proteins is not clear yet, but they may function in the regulation or reduction of the depostion of insoluble calcium salts.

The Gla-containing protein, found in the chorio-allantolc membrane of chicken eggs is supposed to be involved in the Ca ${ }^{2+}$ transport from the egg shell to the developing embryo (110).

Gla-containing proteins have also been discovered in the venom of varlous snakes $(111,112)$. These proteins are also capable of binding to phospholipid micelles and in this way they can activate the blood coagulation process.

In some warfarin-sensitive tumor cells a witamin k-dependent procoagulant protelin has been demonstrated. This protein is a cysteine proteinase with factor $X$ activating properties (113).

\section{VITAMIN K-DEPENDENT CARBOXYLASE IN HUMAN TISSUES}

In microsones from human liver (114) and placenta $(114,115)$ vitamin $K$ dependent activity was demonstrated. No substantial differences were found between the vitamin $K$-dependent carboxylase systems in bovine and human Liver microsomes with regard to the Kan values for $F \mathrm{~L} E \mathrm{E} L$ and $\mathrm{KH}_{2}$ and the warfarin concentration which inhibits $50 \%$ of the activity in the K+DTT stimulated carboxylation reaction. In the microsamal preparations from human livers, however, a rather high amount of endogenous substrate was found as compared to the bovine preprations. The reason for it is not clear yet. Recently, Wallin et al. (116) also demonstrated $K$ - and Ko-reductase activities in microsomal preparations from human liver. The amount of microsomal DT-diaphorase was found to be substantially lower than in rat hepatic aicrosomes. 


\section{INTRODUCTION TO THIS THESIS}

Vitamin $K$ is involved in a postranslational carboxylation reaction, in which specific glutamic acid residues are converted to 4 -carboxyglutanic acid (Gla) residues. This reaction is commonly reported to occur in liver. The importance of the Gla-residues is clearly demonstrated by their role in blood coagulation. The formation of Gla-residues and hence the synthesis of biologically active coagulation factors is inhibited by administration of 4-hydroxycoumarin drugs, which are often used in anticoagulant therapy.

It is presently known that vitamin $k$-dependent carboxylation also accurs in various non-hepatic tissues. Until now, the blological significance of these non-hepatic vitamin $K$-dependent systems is hardly known. Therefore, it was felt necessary to start investigations concerning a) the properties of the non-hepatic vitamin K-dependent enzymes, b) the characteristics of the proteins which are carboxylated by these non-hepatic systers, and c) the effects of the administration of 4-hydroxycoumanin drugs on the non-hepatic systems. Further instght in these aspects may be of relevance for the treatment of patients with 4-hydroxycounarin drugs.

\section{REFERENCES}

1. Dam, H. Biochem. J. 29:1273-1285, 1935

2. Schofleld, E.W. Can. Vet. Rec. 3: 74-79, 1922

3. Campbe11, M.A. and Link, K.P. J. Biol. Chem. L8: 21-33, 1941

4. 01son, R.E. Ann. Rev. Nutr. 4: 281-237, 1984

5. Hemker, H.C., Veltkamp, J.J., Hensen, A. and Loeliger, E.A. Natute $200: 589-590,1963$

6. Ganrot, P.0, and Nilehn, J.E. Scand. J. C1in. Lab. Invest. 22: 23-28, 1968

7. Josso, F., Lavergne, J.M., Gouault, M* Prou-Wartelle, C. and Soulier, J.P. Thromb. Diath. Haemorrhag. 20: 88-98, 1968

8. Nelsestuen, G.L. and SuttLe, J.W. BiochemLstry 11: $4961-4964,1.972$

9. Stenflo, J. and Ganrot, P.0. Blochem. Blophys. Res. Commun. 50: $98-104,1973$

10. Stenflo, J. J. Biol. Chem. 249:5527-5535, 1974

11. Nelsestuen, G.L., Zytokovicz, T.H. and Howard, J.B. J. BLol. Chem. $249,6347-6350,1974$

12. Magnusson, S., Sottrup-Jensen, L., Petersen, T.E*, Morris, H.R. and Dell, A. FEBS Lett * 44: 189-193, 1974

13. Suttie, J.W. and Jackson, C.M. Physiol. Rev. 57: 1-70, 1977

14. Stenflo, J. J. Biol. Chem. 251: 355-363, 1976

15. DiSciplo, R.G. Hermodson, M.A., Yates, S.G. and Davle, E. G. Biochemistry, 22: 2087-2097, 1977 
16. Prowse, C.V., Mattock, P., Esnouf, M.P. and Russel1, A.M. Btochim. Blophys. Acta 434: 265-279, 1976

17. Vemeer, C. Holec. Ce11. Blochen. $61: 17-35,1984$

18. Vermeer, C. and De Boer-v.d. Berg, M.A.G. Haematologia 18, 71-97, 2985

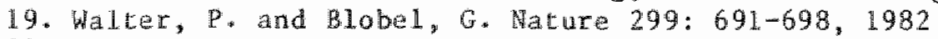

20. Meijer, D.I. and Dobberstein, B. J. Cel1. Biol. 87 : 503-508, 1980

21. Meijer, D.I., Krause E. and Dobberstein, B. Nature 297: 647-650, 1982

22. Friezner Degen, S.J., MacGilivray, R.T.A. and Davie, E.W. Biochemistry 22: 2087-2097, 1983

23. Kurach1, $K$, and Davie, E.W. Proc. Kat1. Acad. Sci. U.S.A. 79: $6461-6464,1922$

24. MacGilivray, R.T.A. and Irain, D.M. Haemostasis 16: 227-238, 1986

25. Canfield, L.M., Sinsky, Taa. and Suttie, J.W. Arch. Biochem. Blophys. 202: $515-524,1980$

26. Wallin, R. and Suttie, J*W. Arch. Biachen. Biophys. 214: 155-163, 1982

27. Olson, R.E., Hall, A.L.. Lee, F.C., Kappel, W.K., Meijer, R.G. and Bettger W.J. In Postranslational Covalent Modiflcations of Proteins (Wohnson, B.C., ed) pp. 295-319, 1983 Academic Press, New York

28. De Metz, M., Vermeer, C., Soute, B.A.M., wan Scharrenburg, G.J.M., Slotborm, A.J. and Hemker, Hi.C. FEBS Lett. 123: 21.5-218, 1981

29. De Met $z, M$. Thesfs, Maastricht. 1982

30. Girardot, J.M. J. B1a1. Chen. 257: 15008-15011, 1982

31. Suttie, J.W. Science 179: 192-194, 1973

32. Bsmon, C.T., Sadowski, J.A. and Suttie, J.W. J. Biol. Chem. 250: $4744-4748,1975$

33. Esmon, C.T. and Suttie, J.W. J. Biol. Chem. 251: 6238-6243, 1976

34. Suttie, J.W. C.R.C. Crit. Rev. Biochem. 8: 191-223, 1980

35. Vermeer, C., Soute, B.A.M., De Metz, M. and Hemker, H.C. Biochin. Blophys. Acta 714: 361-365, 1982

36. Houser, R.M., Carey, D.J., Dus, K.M., Marshal1, G.R. and OLson, R.E. FEBS Lett. 75: 226-230, 1977

37. Suttie, J.N., Hageman, J.M., Lehrman, S.R. and Rich, D.H. J. Biol. Chem. 251: $5827-5830,1976$

38. Suttle, J.W., Lehrman. S.R., Geweke C.O... Hageman., J.M. and Rich, D.H. BLochlm. Blophys. Res. Commun. 86: 500-507, 1979

39. Dhaon, M.K., Lehrman, S.R., Rlch, D.H., Engelke, J.A. and Suttie, J.W. J. Med. Chem. 27: J.196-1201, 1984

40. Soute, B.A.M., Veruter, C., De Metz, M., Herker, H.C. and Lifnen, H.R. Blochtm. Blopliys. Acta 676: 101-1.07, 1981

41. Swanson, J.G. and Suttie, J.W. Biochemistry 21: 6011-6018, 1982

42. Decottignies-Le Marécha1, P., Rlkong-Adie, H., Azerad, R. and Gaudry, M. Biochem. Biophys. Res. Commun. 90:700-707, 1979

43. Finnan, J.L., Goodman, H.L. and Suttie, J.W. In Vitamin K Metabolism and Vitamin $K$ Dependent proteins (ed. J.W. Suttie) pp. 480-483, 1980 Baltimore, Univ. Park Press.

44. Swanson, J.C, and Suttie, J.W. Fed. Proc. 42: 1861 (abstract). 1983

45. Gaudry, M., Bory, S., Dubols, J., Azerad, R. and Marguet, A. Biochem. Btophys. Res. Commun. 113: 454-461, 1983

46. Guibé, E., Decottignies-Le Maréchal, P., Le Marécha1, P. and Azerad, R. FEBS Lett. 177: 265-268, 1984

47. Jones, J.P., Gardner, E.J., Cooper, I.G. and 01son, R.E. J. BIoI. Chem. 252: $7738-7742,1977$

48. Jones, J.P., Fausto, A., Houser, R.M., Gardner, E.J. and O1son, R.E. Blochem. Biophys. Res. Commun. 72: 589-597, 1976 
49. Suttie, J.W., Preusch, P.C. and Mctigue, J.J. In: Posttranslational Covallent Modifications of Proteins (Johnson, 3. e. ed) pp. 253-279, 1983 Academic Press, New York

50. Suttie, J.W. and Preusch, P.C. Haemostasis 16: 193-215, 1986

51. Willingham, A.K. and Matschiner, J.T. Blochen. J. 140:435-44 J, 1974

52. Suttie, J.W., Geweke, L.0., Martin, S. and Willinghat, A.K. FEBS Lett. $109: 267-270,1980$

53. Fasco, M.J., Principe, L.M., Walsh, M.A. and Friedman, P.A. Biochemistry $22: 5655-5660,1983$

54. Preusch, P.C. and Suttie, J.W. J. Org. Chem. 48: 330l-3305, 1983

55. Hildebrandt, E.T., Preusch, P.C., Patterson, J.L. and Suttie, J.W. Arch. Biochem. Biophys. 228: 480-492, 1984

56. Fasco, M.J., Preusch, P.C., Hildebrandt, E. and Suttle, J.W. J. Biol. Cher. $258: 4372-4380,1983$

57. Whitlon, D.S., Sadowski, J.A. and Suttie, J.W. Biochemistry 17: $1371-1377,1978$

58. Fasco, M.J., Hildebrandt, E.F. and Suttie, J.H. J. Biol. Chem. 257; $11210-11212, \quad 1982$

59. Preusch, P.C. and Sutcle, J.W. Arch. Biochem. Biophys. 234: 405-412, 1984

60. Wallin, R., Gebhardt, 0. and Prydz, H. Biochem. J. 169: 95-101, 1978

61. Wallin, R. and Hutson, S. J. Biol. Ghem. 257: 1583-1586, 1982

62. Wallin, R. Biochem. J. 236: 685-693, 1986

63. Bel1, R.G., Sadowski, J.A. and Matshiner, J.T. Biochenistry 11: $1957-1961,1972$

64. Van der Meer, J., Hemker, H.C. and Loeliger, E.A. Thrombos. Dlath. Haemorrh. Supp1. 29:61-63, 1968

65. Roncaglioni, M.C., U1rich, M.M.W., Muller, A.D., Soute, B.A.M., De Boer-van den Berg, M.A.G. and Vermeer, C. Thromb. Res. 42; 727-736, 1986

66. Fasco, M.J. and Principe, L.M. Biochem. Biophys. Res. Commun. 104 : $187-192,1980$

67. Fasco, M.J. and Principe, L.M. J. Biol. Chem. 257: 4894-4901, 1982

68. Lee, J.J. and Fasco, M.J. Biochenistry 23: 2246-2252, 1984

69. Preusch, P.C. and Suttie, J.W. Blochim. Blophys. Acta 798: 141-143, 1984

70. Suttie, J.W. Ann. Rev. Biochem. 54: 459-477, 1985

71. Friedman, P.A., Shia, M.A., Gallop, P.M. and Griep, A.E. Proc. Mati. Acad. Sci. U.S.A. 76:3126-3129, 1979

72. Dubols, J., Gaudry, M., Bory, S., Azerad, R. and Marquet, A. J. Blol. Chem. 258: 7897-78:99, 1983

73. Decottignles-Le Marécha1, P., Ducrocq, C., Marquet, A. and Azerad, R. J. Biol. Chem. 259: 15010-15012, 1984

74. MeTigue, J.J. and Suttie, J.W. J. Bioll. Chem. 258: 12129-12131, 1983

75. Larson, A.E., Friedman, P.A. and Sutt1e, J.W. J. Bfol. Chem. 256: $1.1032-11035,1981$

76. De Metz, M., Soute, B.A.M., Henker, H.C., Fokkens, R., Lugtenburg, J. and Vermeer, C. J. Biol. Chem. 257: 5326-5329, 1982

77. Wiss, O. and Gloor, H. Vit. Horm. 24: 575-586, 1966

78. Thierry, M.J. and Suttie, J.W. J. Nutr. 27: 512-516, 1969

79. Hauschka, P.V., Friedman, P.A., Traverso, H.P. and Gallop, P.M. Blochem. Biophys. Res. Commun. 71: 1207-1213, 1976

80. Friedman, P.A., Mitch, W.E. and silva, P. J. Blol. Chem. 257 : $11037-11040,1982$ 
81. Llan, J.B. and Friedman, P.A. J. Biol. Chem. 253: 6623-6626, 1973

82. Gallop, P.M., LIan, J.B. and Hauschka, P.V. N. Engl. J. Med. 302 : $1460-1466,1980$

83. Nishimoto, S.K. and Price, P.A. J. Biol. Chem. 254: 437-441, 1979

84. Be11, R. G. Arch. Blochem. Blophys. 203: 58-64, 1980

85. Vermeer, C., Hendrix, H. and Daemen, M. FEBS Lett. 148: 317-320, 1982

86. Buchtal, S.D. and Be11, R.G. Blochemistry 22: 1077-1082, 1983

87. Buchtal, S.D., McAllister, C.G., Laux, D.C. and Bell, R.G. Biochem. Blophys. Res. Commun. 109: 55-62, 1982

88. Roncaglloni, M.C., Dalessandro, A.P.B., Casali, B., Verneer, C. and Donat1, M.B. Haemostasis 16: 295-299, 1986

89. Traverso, H.P., Hauschka, P.V. and Gallop, P.M. In: Vitamin K Metabolism and Vitamin $\mathbb{K}$ Dependent Proteins, (ed. Suttie, J.W.) pp. 311-31.4, 1.980 Baltimore Park Press

90. Hofrup, P., Roepstorff, P. and Petersen, T.E. Eur. J. Blochem. 126: $343-348,1982$

91. Kisiel, W., Canfield, W.M., Ericsson. L.H. and Davie, E.W. Blochemistry 16: $5824-5831,1977$

92. Stentlo, J. Sem. Thromb. Hemost. 10: 109-121, 1984

93. Stenflo, J. and Jönsson, M. FEBS Lett. 101: 377-381, 1979

94. Falr, D.S., Marlar, R.A. and Levin, E.G. Blood 67: 1168-1171, 1986

95. Rosing, J., Tans, G., Govers-Riemslag, J.W.P., Zwaal, R.F.A. and Herker, H.C. J. Bio1. Chem. 255: 274-283, 1980

96. Llan, J.B., Prlen, E.L., Glimcher, M.J. and Gallop, P.M. (1977) J. Cl1n. Invest. 59: 1151-1157, 1977

97. Nakagawa, Y., Abram, V., Kezdy, E.T., Kaiser, F. and Coe, L. J. Biol. Chem. 257: 12594-1.2600, 1983

98. Price, P.A., Otsuka, A.S., Poser, J.W., Kristapolis, J. and Raman, N. Proc. Nat1. Acad. Sci. U.S.A. 73: 1447-1451, 1976

99. Poser, J.W., Esch, F.S., Ling, N.C. and Price, P.A. J. Biol. Chem. 255: $8685-8691,1980$

100. Loeliger, E.A. in: Side Effects of Drugs Annual (Dukes, M.N.G. ed) vo1. G pp. 304-314. 1982 Excerpta Medica, Ansterdam

101. Price, P.A., Williamson, M.K., Haba, T., Dell, R.B. and Jee, W.S.S. Proe. Nat1. Acad. Se1. 79:7734-7738, 1982

102. Vermeer, C., Soute, B.A.M., Ulrich, M.M.W. and V.d. Loo, P.G.F. Hemostasis $16: 246-257,1986$

103. Price, P., Urist, M.R. and Otawara, X. Biochem. Biophys. Res. Commun. $117: 765-771,1983$

104. Levy, R.J., Ltan, J.B. and Gallop, P. Biachem. Blophys. Res. Commun. 91: $41-49,1979$

105. Keeley, F.W. and Sitarz, E.E. Atherosclerosis 46: 29-40, 1983

106. Levy, R.J., Howard, S.L. and Oshry, L.J. Atherosclerosis 59: 155-160, 1986

107. Linde, A., Bhown, M., Cothran, W.C., Höglund, A. and Butler, W.F". Biochim. Biophys. Acta 704: 235-239, 1982

108. Lian, J.B., Skinner, M., Glimcher, M.J. and Gallop, P. Biochem. Biophys. Res. Commun. 73: 349-355, 1976

109. Hamilton, S.E., King, G., Tesch, D., Riddles P.W., Keough, D.T., Jell, J. and Zerner, B. Blochem. Blophys. Res. Commun. 108: 610-613, 1982

110. Tuan, R.S. J. Biol. Chem. 254: 1356-1364, 1979

111. Tans, G., Govers-Riemslag, J.W.P. Van Rijn, J.L.M.L. and Rosing, J. J. Biol. Chem. 260: $9366-9372,1985$ 
112. Speijer, H. Govers-Rienslag, J.W.P., Zwal, R.F.A. and Rosing, J. 261: $13258-13267,1986$

113. Donati, M.B., Roncaglioni, M.C., Falanga, A., Casali, B., Semeraro, N. Haemostasis $16: 288-294,1986$

114. Soute, B.A.M., De Metz, M. and Vermeer, C. FEBS Lett. 146: 365-368, 1982

115. Friedman, P.A., Hauschka, P.V., ShIa, M.A. and Wallace, J.K. Blochem. Biophys. Acta 583: 261-265, 1979

116. Wallin, R. aud Martia, L.F. J. C1in. Invest. 76: 1879-1884, 1985 



\section{VITAMIN K-DEPENDENT CARBOXYLASE IN SKIN}

M.A.G. de Boer-van den Berg, C.P.H.J. Verstijnen and C. Vermeer

\section{SUMMARY}

Vitamin $\mathrm{K}$-dependent carboxylase 1 s demonstrated in skin microsomes from man, rat, rabbit and nouse. This enzyme converts a number of distinct protein-bound glutamic acid residues into 4 -carboxyglutamic acid residues, which strongly interact whth $\mathrm{Ca}^{2+}$ ions. The enzymatc activity (expressed per mg protein) in skin is about 20\% from that in liver. Vitamin $\mathrm{K}$-dependent carboxylase is present in both epidermic and dermic tissue. It is demonstrated that warfarin treatment in mice results in an accumulation of non-carboxylated precursor protelns in both dermic and epidermic microsomes. Most probably this effect of warfarin 1 s not restricted to mice, but occurs also in the skin of patients under oral anticoagulant therapy.

A possible relation between vitamin $K$-dependent skin carboxylase and the 4-carboxyglutamic acid-containing protein in calcified nodules from patients with scleroderma and dermatomyositis is discussed. 
INTRODUCTION

Vutamin $K$ is involved in a posteranslational modification of proteins $(1,2)$. This modification consists of the carboxylation of a number of distinct glutamic acid residues into 4-carboxyglutamic acid residues (Gla). The presence of Gla has initially been discovered in blood cosgulation factors, whlch are synthestzed in the liver $(3,4)$. The Gla-rich regions are essentlal for the proper functioning of these coagulation factors. Coumarin derivatives, such as warfarin, inhibit the formation of Gla-residues and therefore they are used as anticoagulants (5).

For a long perlod it has been thought, that the vitamin K-dependent carboxylation was restricted to the liver. During the last decade, however, slinilar enzyme systems have been detected in various other tissues such as kidney, spleen, test1s, 1 ung and vessel wall $(6,7)$. In wivo, the administration of low doses of warfarin affects both the hepatic as well as the non-hepatic carboxylase systems (8). It is to be expected that all these vitamin $K$-dependent enzymes are involved in the production of Gla-containing proteins, but in most cases their precise function and even their place of action are unknown. Gla-containing proteins have been demonstrated in for instance bone (9), renal stones (10), calcified atheromatous plaques (11), calcium containing material extruded from the skin of sclerodema-patients and in the calcifled skin and subcutaneous plaques from patients with dermatomyositis (12). Whereas it has been suggested that the bone Gla-protein is synthesized by the osteoblasts (13), the origin of the Gla-contalning proteins in the calcified plaques occurring in the skin diseases mentioned above has remained obscure until now. It was of interest therefore, to examine skin tissue for the presence of vitamita $\mathrm{K}$-dependent carboxylase. The results of our investigations are presented in this paper.

\section{MATERIAL AND METHODS}

\section{Materials}

Vitamin $K_{1}$ (konakion ${ }^{R}$ ) was obtained from Hoffmann-La Roche (Basel, Swltzerland). Vitamin $K$ hydroquinone was prepared as described earlier 
(13). 3-([3-cholamidopropy1])dimethy 1-amonio)-1-propane sulfonate (CHAPs), dithiothreitol (DTT) and warfarin were from Sigma (St. Louis, U.S.A.) and the syntheric pentapeptide Phe-Leu-GIu-Glu-Leu (F L E E L) was from Vega Biochemicals (Tucson, U.S.A.) $\mathrm{NaH}^{14} \mathrm{CO}_{3}(40-60 \mathrm{Cl} / \mathrm{mol}$ ) was purchased from Amersham (Amersham U.K.) and Atomlight from New England Nuclear (Drelelch, FRG). Dispase protease neutrale from Bacillus polymixa grade II was obtained from Boehringer Mannheim (Mannhein, FRG). All other chemicals were from Merck (Darmstadt, FRG). Athymic, hairless mice, strain MMRI, nu/nu were obtained from TNo (Zeist, The Netherlands).

\section{Methods}

Skin tissue was obtalned from 12-16 weeks old hairless, athymic mice, newborn Lewis rats and newbor Hollander rabbits, shortly after the animals were sacrificed under ether anaesthesia. Skin tissue from man without known skin diseases was obtained from the Departments of Pathology in hospltals at Mastricht and Amsterdan. All pieces of skin tissue were obtalned less than 3 hours after death and they were immediately frozen at $-80^{\circ} \mathrm{C}$. For some experiments, livers, kidneys, lungs and testes were excised from athymic mice shortly after their sacrifice. For some experiments these mice were injected intraperitoneally with warfarin dissolved in $150 \mathrm{mM}$ NaCl, $\mathrm{pH}$ 7.4, in a dose of $10 \mathrm{mg}$ per $\mathrm{kg}$ body welght, 18 hours before sacrifice.

Epidermal. tissue was separated fron the underlaying connective tissue by dispase treatment. Therefore we slightly modified the method described by Kitano et a1. (15). Skin tissue was cut into pieces of about $2 \times 4 \mathrm{~cm}$ and incubated at room temperature with $150 \mathrm{ml} 0.5 \%$ dLspase (w/v), $0.15 \mathrm{NaCl}$ pH 7.4 , during 4-6 hours. After this incubation the skin could be divlded into epidermis and dermis with a small spatula. To control the separation, pleces of tissue were fixed in phosphate buffered formalin and embedded in paraffin. $4 \mu \mathrm{m}$ tissue sections were stained with hematoxylin or azan and examined with a light microscope.

The microsomal fractions of the tissues were prepared in a simliar way as described earlier (6). After three washing cycles the microsomes were suspended in buffer A $(0.1 \mathrm{M} \mathrm{NaC1}, 0.05 \mathrm{M}$ Tris-HC1, pH 7.5, $1 \mathrm{mM} \mathrm{EDTA,} \mathrm{20 \%}$ $(v / v)$ ethyleneglycol) to a concentration of $3-10 \mathrm{mg}$ protein per ml and stored at $-80^{\circ} \mathrm{C}$.

The carboxylase activity was measured by incubating $0.25 \mathrm{ml}$ reaction mixtures at $25^{\circ} \mathrm{C}$ in buffer A, containing $0.4 \mathrm{mg}$ microsomal proteln, $0.1 \mathrm{mg}$ 
CHAPS, 10 mM F LE E L, 8 mM DTT, $0.2 \mathrm{mM}$ witami K hydroquinone, $0.01 \mathrm{mCi}$ $\mathrm{NaH}^{1 / 4} \mathrm{CO}_{3}$ and $1 \mathrm{M}\left(\mathrm{NH}_{4}\right)_{2} \mathrm{SO}_{4}$. The reaction was stopped and non-bound ${ }^{14} \mathrm{CO}_{2}$ was renoved by adding trichloroacetic acid $(5 \%)$ and degassing the solution for 2 min at elevated temperatures. The samples were supplemented with 10 ml Atomlight and counted in a Beckman scintiliation counter. Since under the incubation conditions all reaction components are present in excess, the inflal reaction rates are proportional to the respective arounts of carboxylase. To measure the amoun of endogenous substrate no $F L E L$ was added to the reaction mixture. In all experiments parallel incubations were performed in the absence of vitamin $K$ hydroquinone and DTT; these blank values were subtracted. It was ascertalned that dispase had no effect on the carboxylase-activity measurements.

Protein concentration was determined according to Sedmak and Grossberg (16).

Gla restdues were determined by alkaline hydrolysis of homogenized tissue and subsequent HPLC analysis on a Nucleosil 5SB column (Chrompack) as described by Kuwada and Katayama (1.7).

\section{RESULTS}

The detection of vitamin $\mathbf{K}$-dependent carboxylase activity

SkIn tissue was obtained from man, hairless mice and from newborn rats and rabbits. After tissue homogenization the microsomal fractions were prepared. In all these species vitamin $\mathbb{K}$-dependent carboxylase activity could be demonstraced (table $\mathbb{I}$ ). The rather low amounts measured in the rabbit and rat preparations may be caused by a less efflcient homogenization of the tissues. All experiments described below were performed with hairless milce as their skin is most readily homogenized.

To compare the amounts of vitamin $k$-dependent carboxylase activity in skin and other tissues we also prepared the microsomal fractions of 1 iver, kidney, spleen and testes from the same animals. In all microsomal preparations carboxylation proceeded in a linear way for at least 30 min. The skin carboxylase activity is comparable with that in other non-hepatic tissues, but much lower than the liver carboxylase activity (table II). The 
Table I

Vitamin $K$-dependent carboxylase activity in skin from varlous species

\begin{tabular}{lc}
\hline specles & $\begin{array}{c}\text { carboxylase activity } \\
\text { (dparmin per mg protein) }\end{array}$ \\
\hline man & 500 \\
rabbit & 105 \\
rat & 200 \\
mouse & 590
\end{tabular}

Microsomes were prepared from about $10 \mathrm{~g}$ of skin tissue, and carboxylase activity was measured as described in Materials and Methods. Blank values without added $\mathrm{KH}_{2}$ and DTT $(15-30 \mathrm{dpm} / \mathrm{min}$ per mg protein) were subtracted. The data are the mean of duplicate measurements.

Table II

Vitamin $K$-dependent carboxylase activity in various tissues from athymic mice

\begin{tabular}{|c|c|c|c|}
\hline tissue & \multicolumn{2}{|c|}{${ }^{14} \mathrm{CO}_{2}$ Incorporated (dpm) } & $\begin{array}{l}\text { relative carboxylase } \\
\text { activity }(\%)\end{array}$ \\
\hline skin & 6470 & 245 & 100 \\
\hline liver & 36200 & 200 & 580 \\
\hline kidney & 3810 & 340 & 56 \\
\hline lung & 12010 & 220 & 190 \\
\hline spleen & 2720 & 370 & 38 \\
\hline testis & 5250 & 290 & 80 \\
\hline
\end{tabular}

The vitamin K-dependent carboxylase activitles are given as the amount of $\mathrm{CO}_{2}$ incorporated in $25 \mathrm{~min}$ in the presence and absence of vitamin $\mathrm{KH}_{2}$ and DTT. All reaction mixtures contained $0,4 \mathrm{mg}$ of microsomal proteln. In the last column the activities are expressed as a percentage of the skin carboxylase activity per mg microsomal proteln. 

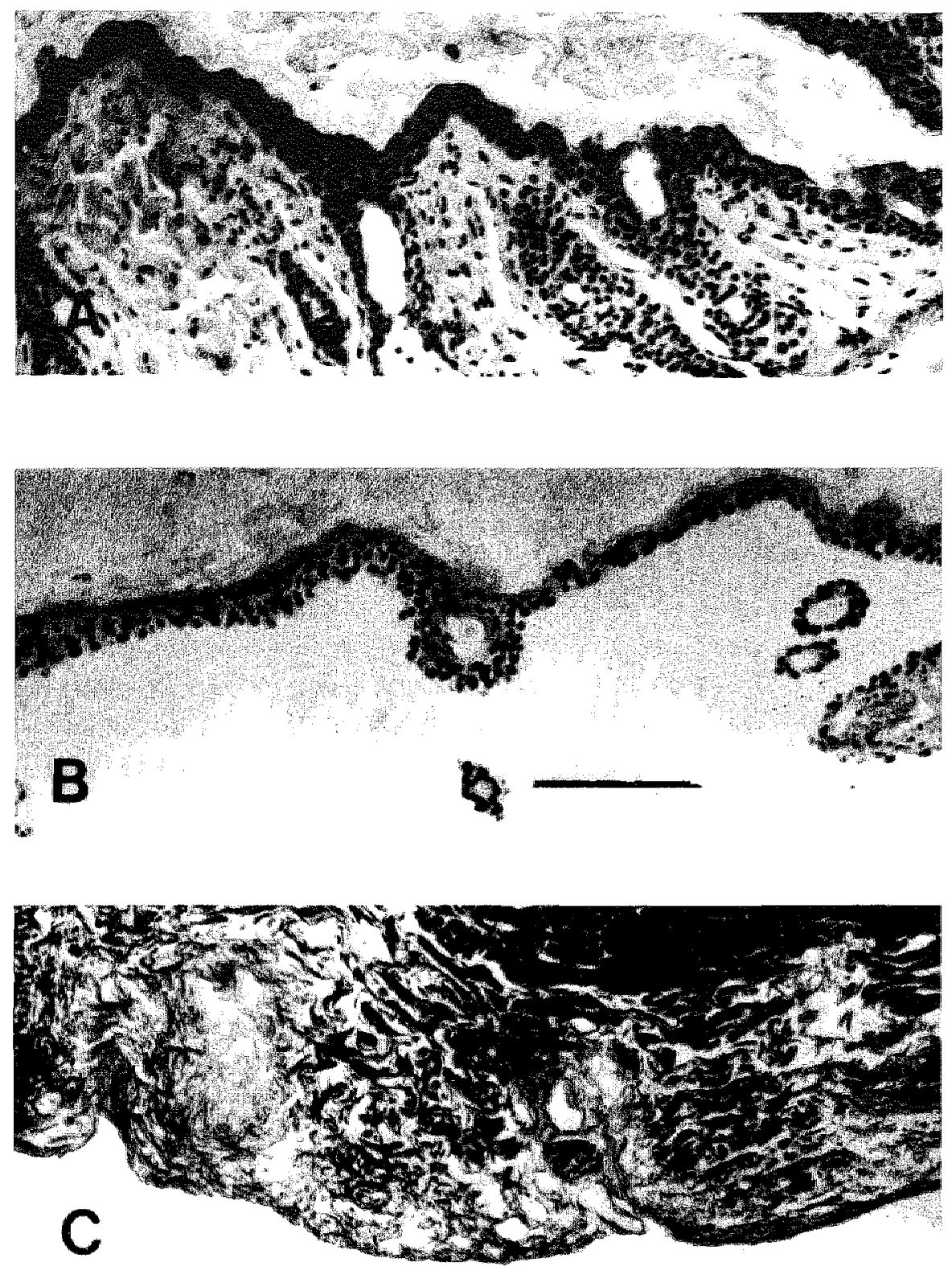

Fig. 1 Skin tissue of athymic mice

A: Skin before dispase treatment, stained with hematoxylin

B: Epidermis, btained with hematoxylin

C: Demis, stained with azan

$B a r^{2}=0.1 \mathrm{~nm}$ 
ratio between the enzyme activities in liver, kidney, spleen, lung and testes microsomes from these mice is in reasonable agreenent with results earlier found for rats ( 7 ).

The localization of skin carboxylase

In earlier experiments we demonstrated a considerable vitanin K-dependent carboxylase activity in bovine vessel wall. It cannot be excluded that this vascular enzyme accounts, at least partly, for the carboxylase activity demonstrated in nicrosomes derived from several wholle tissue homogenates. Experiments were undertaken to investigate whether the skin carboxylase activity could be attributed to the vascular vitamin $\mathrm{K}$-dependent carboxylase system. As the epldermis does not contaln any blood vessels, skin was separated into epidermic and dermic tissue by dispase treatment. It was ascertained by histological techniques that the epidermic cells did not contain any detectable amount of dermic tissue and vice versa (fig. 1). Carboxylase activity was detected in both microsomal preparations. The carboxylation rate was constant for about $30 \mathrm{~min}$ as is shown $1 \mathrm{n}$ fig. 2 .

Effects of warfarin treatment in vivo

In liver, warfarin treatment causes the accumulation of non-carboxylated precursors of blood coagulation factors. A part of these precursors remain firmly bound to the talcrosomal carboxylase-complex and can be carboxylated in vitro (endogenous substrate). We investigated whether a similar effect of warfarin would occur in skin tissue. Athymic nice were injected intraperitoneally with a dose of $10 \mathrm{mg}$ warfarin per $\mathrm{kg}$ body weight. After 24 hours the mice were sacriflced, the skin was removed and the 1 ivers and kidneys were exclsed. Microsomes were prepared and the amounts of endogenous substrates were measured. In all preparations an increase of non-carboxylated precursor protelns was demonstrated after warfarin treatment (table III). This increase was comparable in skin and kidney, whereas in liver a higher level of endogenous substrate was detected. This is in agreement with earlier results abtalned from bovine and rat experiments in which invariably a higher accumulation of endogenous 


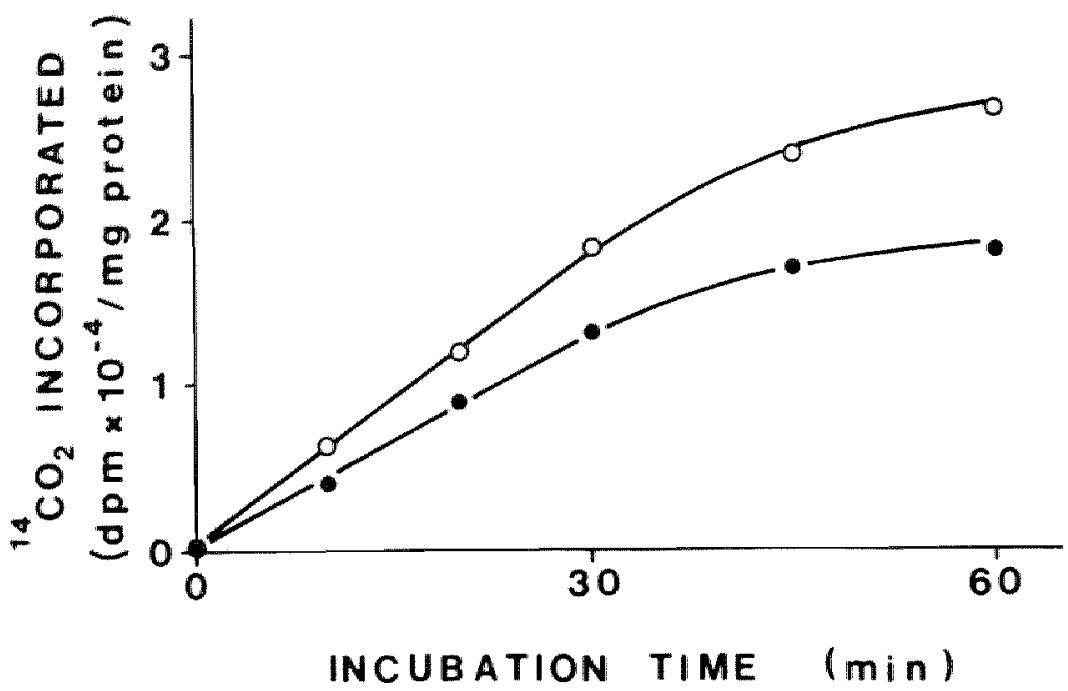

Fig. 2 Time course of vitamin $K$-dependent carboxylation

The carboxylation was performed as described in Materials and Methods. Btank values without added vitamin $K H_{2}$ and DTT $(200-450$ dpm per incubation, were subtracted.

- dermis microsomes

0-o epidermis mierosomes

substrate was found in liver than in other tissues $(6,7,8)$. The sum of the quantities of endogenous substrate found in the microsomes from isolated dermic and epldermic tissue was slightly lower than the amount of endogenous substrate found in total skin milcrosomes. This was due to the dispase treatment. Nevertheless, an increase of non-carboxylated precursors proteins was demonstrated after warfarin treatment in epidermis and dermis as we11. To determine if $\left[{ }^{1 / 4} \mathrm{C}\right]$ Gla was formed in the precursor proteins, incubated samples of microsomes from warfarin treated mice were heated at $110^{\circ} \mathrm{C}$ in $6 \mathrm{~N} \mathrm{HCl}$ for $24 \mathrm{~h}$. This treatment resulted in a 10 ss of $59 \%$ of the bound ${ }^{14} \mathrm{C}$ in total skin microsomes, $47 \%$ in dermic microsomes, $56 \%$ in 
Table III

Amounts of accumulated endogenous substrate after warfarin treatnent

tissue amounts of endogenous substrate
(dpro/60 min per mg protein)

normal after warfarin treatment

$\begin{array}{lrr}\text { liver } & 4970 & 14460 \\ \text { kidney } & 770 & 1540 \\ \text { skin } & 1260 & 2560 \\ \text { dermis } & 970 & 2000 \\ \text { epidermis } & 800 & 2230\end{array}$

Warfarin was given intraperitoneally in a dose of $10 \mathrm{mg} / \mathrm{kg}$ body weight to 16 athymic mice. Microsomes were prepared from the pooled tissues of normal and warfarin treated mice respectively and endogenous substrate was measured as described in Materials and Methods. Blank values (250-500 $\mathrm{dpm} / 60 \mathrm{~min}$ per $\mathrm{mg}$ protein) were subtracted. The data are the meam of triplicate measurements.

epidermic microsomes and $54 \%$ in liver microsones. The theoretical loss of ${ }^{14} \mathrm{C}$ from $\left[{ }^{14} \mathrm{C}\right]$ Gla labeled in one of the carboxyl groups would be $50 \%$. From these results we concluded that under our experimental conditons Gla-residues had been formed by skin microsomes.

The presence of vitamin $\mathrm{K}$-reductase

In bovine liver and non-hepatic microsomes, vitamin K-dependent carboxylase has been shown to be closely linked to another enzyme, witamin K reductase. The latter enzyme 1 s responsible for the reduction of vitamin $K$ quinone to vitamin $K$ hydroquinone, which is an essential cofactor in the carboxylation reaction. To detect the presence of vitamin $k$ reductase in dermis and epidermis, in vitro carboxylation studies were puerformed with vitamin $K$ quinone as a cofactor instead of vitamin $K$ hydroquinone. The carboxylation rates were about $50 \%$ of the vitamin $K$ hydroqulnone stimulated reaction for dermis, epidermis as well as for total skin microsomes. This 
Is comparable with previous results found in bovine liver microsomes. In addition, the in vitro inhibition by wafarin of vitamin $k$ quinone reductase was measured. The carboxylation was carried out with vitamin $\mathbb{R}$ quinone as a cofactor and at various watfarin concentrations. In all microsomal preparations, a warfarin concentration of 0.002 m inthited the carboxylation rate for $50 \%$. From these results we concluded that vitamin $k$ reductase is present in both dermic and epldermic microsomes.

\section{DLSCUSSION}

It has been well established, that the vittamin $k$-dependent carboxylation reaction is not restricted to the liver, but that it accurs In many non-hepatic tissues as wel1 $(6,7)$. In a previous study we have also derionstrated that the vitamin $K$-dependent carboxylases from bovine liver, kidney, lung and testis may be regarded as a group of iso-nzymes, which malnly differ in thelr substrate specificity (18). In the present paper we report the discovery of vitamin k-dependent carboxylase in skin and, like in other tissues, the enzyme is located in the microsomal fraction of tissue homogenates. It remains to be investigated whether skin carboxylase is ldentlical wh the of the previously discovered carboxylases or if it is another distinct member of the group of vitamin $\mathrm{K}$-dependent carboxylases.

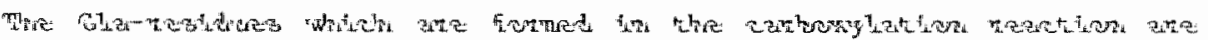
known to bind strongly and selectlwely to $\mathrm{Ca}^{2+}$. The Gla-containing protelns discovered up till now may be classifled as follows (2):

a) Gla-proteins in blood plasma (e.g. varloug coagulation factors), which are all able to bind to phospholipid surfaces via the complexed $\mathrm{Ca}^{2+}$;

b) Gla-proteins found in depositions of insoluble calcium salts such as bone, dentin, renal stones and atheromatous plaques;

c) membrane-bound Gla-proteins, examples of which are found in the kidney and in the chorioallantolc membrane of chlcken eggs and

d) protelns which do not fit in one of the three former groups, such as a snail neurotoxin (18) and the Gla-protein in spermatozoa.

Whereas most of the Gla-proteins found in plasma are involved in the process of blood coagulation, the function of the other proteins is less clear at this moment. 
In an attempt to estimate the physiological importance of skin carboxylase, we have tried to identify its putative product. Obviously, this should be a Gla-containing protein and we have tried to find such a protein in $\mathrm{KOH}$ extracts of hair and nal, in sweat and in normal human and animal skin homogenates. In none of these products Gla could be detected. However, skin homogenates, like liver homogenates, contain too many proteins to detect Gla without further purification. On the other hand a Gla-containing protein has been reported to occur th the pathologlcal depositions of calcified material in the skin of patients suffering from scleroderma and dermatomyositis (12). Obviously the latter protein belongs to the category mentioned under b) (see above), but whether it is indeed produced by skin carboxylase is not sure at this moment.

Speculating about the function of the skin Gla-protetn we would like to mention two possibilities. In the first place the proteln might play a role in the calcium metabolism in skin. Indications in favour of this hypothesis were obtained from clinical studies in which patients with dermatomyositis and massive depositions of subcutaneous calcific nodules were treated with low doses of warfarin. This treatment induced a profound and rapid decrease of the calcified lestons (20). As warfarin inhibits the formation of Gla, these data suggest a possible role for the skin Gla-protein in the regulation of the calcification process.

Alternatively, also a pathological effect of warfarin on skin has been described: especially during the early stages of oral antlcoagulant treatmenc skin necrosis may occur (21). It has been proposed that the latter phenomenon may be the result of an increased thrombogenic activity in the capiliaries induced by an protein $C$ deficlency (22). Protein $C$ is a Glacontaining plasma protein, produced by the liver and does have antlcoagulant activity (23). Without doubts its symthesis is inhtbited by warfarin. It is remarkable however, that the disturbed balance between protefn $C$ and the vitamin K-dependent coagulation factors has only been reported to cause ischemic necrosis of capillaries in skin and not in other tissues. Therefore another protein may also be involved in the accurence of this type of thrombosis. Such a protein might be the putative skin Gla-protein which is produced by skin carboxylase. In this paper we have shown that coumarin derivatives directly inhibit skin carboxylase and thus the carboxylation of the skin Gla-protein. This might result in a decreased biological activity 
of the latter, which may play an additional role in the observed skin necrosis.

Obvtously further research is wanted to elucidate the function of the skin Glaprotein and thus the physiological importance of the vitamin k-dependent skin carboxylase.

\section{Acknowledgments}

The authors wish to thank the staff of the departments of Pathology of the Unlversfty Hospltal, Mastricht and the Slotervaart Hospital, Amsterdam for supplying us with human skin, dr. H.C. Hemker, dr. K. Hamulyák, dr. B. Jagtman and $\mathrm{dr}$. P. Mer for their critical remarks and helpful suggestions and Mrs. M. Molenatr-wan de Voort for typing this manuseript.

\section{REPERENCES}

1. Suttie, J.W. Ann. Rev. Biochem. 54: 459-477, 1985

2. Vermeer, C. and de Boer-van den Berg, M.A.G. Haematologia 18: 71-97, 1985

3. Stenflo, J., Fernlund, P., Egan, W. and Roepstorff, P. Prac. Nat1. Acad. Sct. USA 71: 2730-2733, 1974

4. Ne1sestuen, G.L., ZytkovLcz, T.H. and Howard, J.B. J. Biol. Chem. 249; $6347-6350,1974$

5. Sixty Plus Reinfarction Study Research Group. Lancet II, 989-994, 1980

6. Vermeer, C., Hendrix, H. and Daemen, M. FEBS Lett., 148: 317-320, 1982

7. Buchta1, S.A. and Bell, R.G. Blochemistry 22: 1077-1082, 1983

8. Roncagliont, M.C., Soute, B.A.M., de Boer-van den Berg, M.A.G. and Vermeer, C. Biochem. Biophys. Res. Commun. 114: 991-997, 1983

9. Hauschka, P.V., Lian, J.B. and Gallop, P.M. Proc. Nat1. Sc1. USA, 72: $3925-3929,1975$

10. Lian, J.B., Prien, E.L., Glincher, M.J. and Gallop, P.M. J. Clin. lnvest., 59: 1151-1157, 1977

11. Levy, R.J., Lian, J.B. and Gallop, P. Biochen. Biophys. Res. Commun. 91: $41-1.979$

12. Ltan, J.B., Skinner, M., Glincher, M.J. and Gallop, P. Biochem. Blophys. Res . Comm. 73: 349-355, 1976

13. Wishlmoto, S.K. and Price, P.A. J. Biol. Chem. 254: 437-441, 1979.

14. Vermeer, C., Soute, B.A.M., de Metz, M. and Hemker, H.C. Btochim. Biophys. Acta 714: $361-365,1982$

15. Kltano, Y and Okada, N. J. of Dermatol. (Tokyo) 108: 555-560, 1983

16. Sedmark, J.J. and Grossberg, S.E. Anal. BLochem. 79: 544-552, 1977

17. Kuwada, M. and Katayama, K. Ana1. Blochem. 131: 173-179, 1983.

18. Ulrlch, M.M.W., Soute, B.A.M., de Boer-van den Berg, M.A.G. and Vermeer, C. Blochim. Blophys. Acta 830: 105-108, 1985

19. McIntosh, J.M., Ollver., B.M., Cruz, L.J. and Gray, W.R. J. Biol. Chem. $259: 14343-14346,1984$

20. Hamulyăk, K. and Vermeer, C. Neth. J. Med. 28: 305-306, 1985

21. Green, D. New Engl. J. Med. 311: 1578, 1984

22. Broekmans, A.W., Bertina, R.M., Loeliger, E.A., Hofmann, 0 . and Klingemann, H.G. Thromb. and Haemost. 49: 251, 1983

23. Stenflo, J. Semin. Thrombos. Haemost. 10: 109-121, 1984 
THE IN WIVO EFFECTS OF ACENOCOUMAROL, PHENPROCOUMON AND WAREARIN ON VITAMIN $K$ EPOXIDE REDUCTASE AND VITAMIN K-DEPENDENT CARBOXYLASE IN VARIOUS TISSUES DF THE RAT

M.A.G. de Boer-van den Berg, H.H.W. Thijssen and C.Vermeer

\section{SUMMARY}

In rats the in vivo effects of a chronic low dose treatment $( \pm 60$ $\mu \mathrm{g} / \mathrm{rat} / \mathrm{day}$ ) with different coumartns (acenocoumaral, phemprocoumon and warfarin) on hepatic and non-hepatic vitamin K-dependent enzyme systems were compared. The plasma concentrations of the three counarins differed largely but these differences were not reflected in the mlcrosomal coumarlin. contents. The non-hepatic microsomes contained less than $20 \%$ of the coumarins found in liver microsomes. No substantlal differences were observed between the following effects of the three anticoagulant treatments: 
1) The blood coagulation factor activities vere about $10 \%$ of normal.

2) The hepatic mierosomal vitamin $k$ epoxide reductase activity was dimfinished to about $35 \%$ of control values. The vitanin $k$ eporide reductase activities present in kidney, lung, spleen, testis and brain microsomes were less influenced by the counarin treatments; activities ranged between 45 and $65 \%$ of normal.

3) In 11ver microsomes a 15-fold accumulation of non-carboxylated precursor proteins was found; in the non-hepatic microsomes this effect was less pronounced but stlll present.

4) The hepatic vitamin K-dependent carboxylase activity was enhanced but the corresponding non-hepatic enzyme activities were slightly or not affected.

In addition, the effects of a chronic low dose warfarin treatment were compared with those after an acute high dose of the drug.

\section{INTRODUCTION}

Vltamin $K$ is tnvolved in the conversion of peptide-bound glutamic acid residues dinto 4-carboxyglutamic acid residues. This reaction is catalyzed by vitamin $K$-dependent carboxylase, located at the luminal side of the endoplasmic reticulum. In this carboxylation, the active cofactor vitamin $k$ hydrogutnone, is oxidized to vitamin $K 2,3$ enoxide, which is reduced in a second step to witamin $K$ quinone and to vitamin $K$ hydroqulnone by one or more specific reductases $(1-3)$. It is generally belleved now that vitamin $k$ antagonists such as warfarin inhtbit the vitamin $K$ epoxide reductase. The result of this inhibition is that the supply of vitamin $K$ hydroquinone is exhausted, which decreases the rate of the carboxylation reaction. In vivo this sequence of events results in the appearance of descarboxy coagulation factors in blood and in an increase of non-carboxylated precursor proteins in the liver.

For many years it has been thought that vitamin $K$-dependent carboxylation exclusively occurred in the liver to form the blologically active coagulation factors II, VII, $I X$ and X. Administration of warfarin and other coumarin drugs has been used frequently for the control of blood coagula- 
tion during thrombogenic episodes. In the last 10 years, it became evident that vitamin K-dependent carboxylation is a more comon process, also accurring in other tissues such as kidney, lung, spleen, bone and testis $(4,5)$. Obviously, all these enzyme systems will produce 4-carboxyglutamic acid-containing proteins, but only few of them have been isolated and characterized. Since the only known function of 4-carboxyglutanic acid residtes is a selective interaction with $\mathrm{Ca}^{2+}$ ions, it may be expected that these proteins are involved in $\mathrm{Ca}^{2+}$ metabolism, $\mathrm{Ca}^{2+}$ transport or $\mathrm{Ca}^{2+}$ phospholipid interactions (6). In an earlier study concerning rat liver, lung, spleen and testis carboxylase wave reported that the in vivo administration of a low dose of warfarin affected both the hepatic and nonhepatic vitamin $K$ dependent systems. This was demonstrated by the accumulation of non-carboxylated precursor proteins in the various tissues (7).

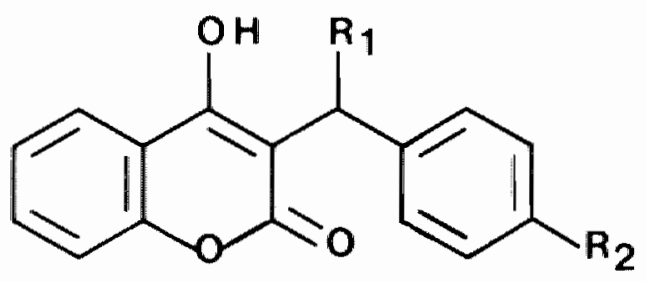

$R_{1} \quad R_{2}$

$\begin{array}{lll}\text { ACENOCOUMAROL } & \mathrm{CH}_{2} \mathrm{COCH}_{3} & \mathrm{NO}_{2} \\ \text { PHENPROCOUMON } & \mathrm{CH}_{2} \mathrm{CH}_{3} & \mathrm{H} \\ \text { WARFARIN } & \mathrm{CH}_{2} \mathrm{COCH}_{3} & \mathrm{H}\end{array}$

Fig* 1 .

Stmuctural formulas of acenacoumarol, phenprocoumon and warfarin. 
Recenty Thijgsen et al. showed the presence of vitamin $R$ epoxide reductase actlvity in rat kidney and testis tissue (8). Whereas single doses of warfarin (up to $1 \mathrm{mg} / \mathrm{kg}$ ) hardly affected the non-hepatic witarin $k$ epoxide reductase activity, a more pronounced effect was observed after chronic warfarin administration. In liver, the enzymatic activity appeared to be moce decreased than in kidney and testis. Differences in the tissue distribution of warfarin were postulated to be responsible for the observed selectivity*

Since in Europe, instead of wararin two other vitamin $k$ antagonists, acenocoumarol and phenprocoumon, are generally used for oral anticoagulant therapy in man, it seemed interesting to compare the effects of the adminfstration of the three coumarin drugs (for structures see fig* l) on the vitamin $k$-dependent systems in various tissues. The results of these investigations are presented in this paper.

\section{MATERIALS AND METHODS}

\section{Materials}

Phenprocoumon (Marcoumar ${ }^{R}$ ) and water-solubilized vitamin $K$ (Konakion ${ }^{R}$ ) were obtained from Hoffman-La Roche (Switzerland) and witamin K hydroquinone was prepared as described earlier [ 9$]$. Pure vitamin $K$ was obtained from Merck (F.R.G.) and whamin $K 2,3$ epoxide was prepared from it according to the method of Tishler et al. (10). Warfarin, dithiothreitol, tocopherolacetate and 3-([3-cholamidopropyl]dimethyl-amonio)-1-propane sulfonate (CHAPS) were purchased from Sigma (U.S.A.) and acenocoumarol (Sintrom ${ }^{\mathrm{R}}$ ) from Ciba Gelgy (Switzerland). The synthetic substrate Phe-Leu-G1u-Glu-Leu (FLEEL) was obtained from Vega Blochemical Co (U.S.A.), $\mathrm{NaH}^{14} \mathrm{CO}_{3}(50-60 \mathrm{CH} / \mathrm{mol})$ from Amersham (U.K.) and Atomlight from New England Nuclear (F.R.G.) A Lichrosorb 5 RP18 colum (150 x $4.6 \mathrm{~mm}$ ) was obtatned from Chrompack (The Netherlands). All other chemlcals were obtalned from Merck (F.R.G.).

\section{Methods}

Male Lewls rats, 10-12 weeks old, were used throughout the experiments. Warfarin, acenocounarol or phenprocoumon was dissolved in $20 \mathrm{mM}$ phosphate buffer pH 9 to a final concentration of $6.5 \mu$ mol/1. The rats received these 
solutions as their sole source of drinking water, the daily intake was approximately $30 \mathrm{~m} 1 \pm 60 \mu \mathrm{g}$ coumarin). Control rats received only phosphate buffer. In some experiments a wafarin solution was administered intraperitoneally in a dose of $20 \mathrm{mg} / \mathrm{kg}$ body welght. Before sactificlng the rats under ether anaesthesia, $4.5 \mathrm{~m} \mathbb{l}$ blood was taken from the aorta and mixed immediately with $0.5 \mathrm{ml} 0.1 \mathrm{M}$ trisodiumcitrate. Coagulation factor activities were determined with specific reagents according to van Dam-Mieras et a 1 . (11).

Variaus tissues i.e. Ifver, kidney, spleen, testis, lung, brain, heart and femoral muscle were excised, rinsed with buffer A $0.1 \mathrm{M} \mathrm{NaC1,} 0.05 \mathrm{M}$ Tris-HCL, $\mathrm{pH} 7.5,1 \mathrm{mM}$ EDTA, $20 \%$ ethyleneglycoll and imediately frozen at $-80^{\circ} \mathrm{C}$ until further use. After thawing, the livers, kidneys etc. of one group of at least five experimental rats were pooled and microsomes were prepared in a similar way as described before (12). Afcer three washing cycles the microsomes were suspended in buffer A containing $1 \mathrm{M} \mathrm{NaCl}$, to a concentration of $10-30 \mathrm{mg}$ protein $/ \mathrm{ml}$ and stored at $-80^{\circ} \mathrm{C}$. Protein concentrations were deternined according to Sedmak and Grossberg (13).

The concentration of warfarin, acenocoumarol and phenprocoumon was determined in plasma, tissue homogenates and microsomes using an HPLC assay, as described previously (14). Calculations were made from the peak area ratios 4-hydroxycoumarin/internal standard and a calibration curve.

The vitamin $\mathrm{K}$ dependent incorporation of ${ }^{14} \mathrm{CO}_{2}$ was measured by incubating $1 \mathrm{mg}$ microsomal protein in $0.25 \mathrm{ml}$ reaction mixture in buffer $\mathrm{A}$, supplemented with $8 \mathrm{mM}$ dithiothreitol, $0.2 \mathrm{mM}$ vitamin K hydroqulnone, $4 \mathrm{mM}$ F L E E L, $0.2 \%$ CHAPS $(\omega / v), 0.01 \mathrm{mCl} \mathrm{NaHH}^{14} \mathrm{CO}_{3}$ and $1 \mathrm{M}\left(\mathrm{NH}_{4}\right)_{2} \mathrm{SO}_{4}$. Incubation was performed in a waterbath at $25^{\circ} \mathrm{C}$ under occastonal shaking. The reaction was stopped and non-bound ${ }^{14} \mathrm{CO}_{2}$ was removed by adding 1 m1 trichloroacetic acid $(5 \%)$ followed by degassing the reaction mixture for 2 min at elevated temperatures. The samples were supplemented with $10 \mathrm{ml}$ Atomlight and counted in a Beckman scintillation counter. Under the conditions mentioned above, the reaction rates were linear for at least 20 min for all tissues examined. The ${ }^{14} \mathrm{CO}_{2}$ incorporation in each sample was measured after 5,10 and 20 minutes incubation and the carboxylase activity is expressed as dpm incorporated ${ }^{14} \mathrm{CO}_{2}$ per min per mg proteln. To measure the amount of non-carboxylated precursor protelns (endogenous substrate), 


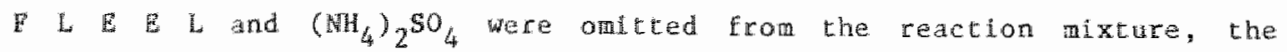
incubation time was prolonged to 60 min and $2.5-4 \mathrm{mg}$ microsomal proteins were used per incubation. The amount of the endogenous precursor proteins 1s expressed as dpm incorporated ${ }^{14} \mathrm{CO}_{2}$ per $h$ per mg protein. In all experiments, parallal incubations were performed in the absence of vitamin $K$ hydroquinone and dithlothrettol. Thase blank values were subtracted.

To determine vitamin $k$ epoxlde reductase activity, 1 mg of microsoma 1 proteln was nixed with $0.02 \mathrm{M}$ Tris-HCl, $\mathrm{pH} 7.4,0.15 \mathrm{M} \mathrm{KCl}$ to a final volume of $0.5 \mathrm{ml}$. After $3-5$ min preincubation in a shaking waterbath at $30{ }^{\circ} \mathrm{C}$, dithlothreitol was added to a final concentration of $5 \mathrm{mM}$ and the muxture was incubated for another 3 min before adding 0.05 umol vitamin $x$ epoxide as substrate. Vttamin $k$ epoxide was dissolved in propanol-2 (10 umol vitamin $K$ epoxide/ml). Liver microsomes were incubated for 20 min; mlcrasomes from other tissues for 45 min. It was ascertained that the reaction rates were linear for at least $1 \mathrm{~h}$. The reaction was stopped by mixing $0.4 \mathrm{ml}$ of the reaction mixture with $4 \mathrm{~m} 1$ of propano $1-2 / \mathrm{H}_{2} \mathrm{O}$ (3:1, $v / v)$. To prevent the formation of association products of witamin $K$ epoxide or vitamin $K$ hydroquinone and dithiothreitol due to co-extracted dithiothreitol, we modified the extraction procedure after terminating the reaction as follows: $0.1 \mathrm{ml}$ of a $\mathrm{AgNO}_{3}$ solution $(0.1 \mathrm{M})$ was added immediately and the resulting mixture was briefly shaken on a whirlmix. Tocopherol. acetate was added $(12.5 \mu \mathrm{g}$ in $50 \mu 1$ propano1-2) as an internal standard and the mixture was extracted wth $2 \mathrm{ml}$ hexane by shaking it for 5 $\mathrm{min}$. The hexane layer was washed with $4 \mathrm{ml}$ of a $0.15 \mathrm{M} \mathrm{NaCl}$ solution, and evaporated to dryness at $35^{\circ} \mathrm{C}$ under a stream of nitrogen. The residue was redissolved Imuediately in $0.1 \mathrm{ml}$ of propanol-2.

Analysis was performed by HPLC and UV adsorption at $250 \mathrm{~mm}$. Separation was achleved on a Lichrosorb $5 R P 18$ column using acetonitrile:dichloromethane: water $(100: 10: 1, v / \mathrm{v} / \mathrm{v})$ as the eluent with a flow rate of $2 \mathrm{~mL} / \mathrm{min}$. Retention times were: K-epoxide, 4 min; internal standard, 5,5 min; $k$ quinone, 6,0 min.

The amount of vitamin $k$ quinone formed was determined by comparing the peak helghts of vitamin $K$ quinone and the internal standard with a calibration graph. The vitanin $K$ epoxide reductase activity is expressed as the amount of vitamin $K$ quinone formed per min and per mg microsomal 
protein. Blank incubations without vitamin $K$ epoxide added, were carried out for each tissue. In none of those samples vitamin $k$ quinone could be detected.

\section{RESULTS}

Blood coagulation factor activities.

Male Lewis rats received a low dose of either acenocoumarol, phemprocoumon or warfarin via their drinking water. The daily intake was about 60 $\mu \mathrm{g}$ per rat. After one week the coagulation factor activities as measured in their plasna-samples were all decreased to levels which are therapeutically relevant in man (table $T$ ).

Table I

Coagulation factor activities in plasma of coumarin-treated rats

\begin{tabular}{|c|c|c|c|c|c|}
\hline \multirow[t]{2}{*}{ Treatment } & \multicolumn{5}{|c|}{$\begin{array}{c}\text { Coagulation factor activities } \\
\text { (\% of normal values) }\end{array}$} \\
\hline & II & $\mathrm{V}$ & VII & IX & $\mathrm{X}$ \\
\hline Control & 100 & 98 & 92 & 95 & 92 \\
\hline \multicolumn{6}{|l|}{ Chronic dose treatment with: } \\
\hline acenocoumarol & 10 & 94 & 7 & 16 & 8 \\
\hline phenprocoumon & 11 & 87 & 10 & 23 & 14 \\
\hline warfarin & 14 & 90 & 9 & 15 & .20 \\
\hline Acute high dose of warfarin & 15 & 95 & 2 & 2 & 3 \\
\hline
\end{tabular}

The coagulation factor activities were determined accarding to Van Dam-Mieras et all. (11) in the pooled plasma-samples of each group of 5 rats. The values are expressed as a percentage of a reference value obtained from a plasma-pool of 20 normal Lewis rats. 
Table II.

The amounts of acenocoumarol (A), phemprocoumon (P) and warfarin (W) present In plasma and in the mlerosomal fractions of various tissues

t 1 give

$$
\text { amount of coumarin ( } \mathrm{ng} / \mathrm{m} 1 \mathrm{and} \mathrm{ng} / \mathrm{mg} \text { ) }
$$

$$
\text { chronic low dose treatment }
$$

A

$\begin{array}{ccc}37+10 & 110+35 & 425+13 \\ 30 & 26 & 27 \\ 6 & 2 & 3 \\ 6 & 5 & 3 \\ 3 & 2 & 3 \\ 2 & 2 & 2\end{array}$

acute high dose

W

$12670+340$

18

2

4

2

3

The anount of coumarin was determined using an HPLC method as described in Materials and Methods. Values are expressed as ng coumarin/ml plasma + SD and ng coumarln/mg microsoma protein. The microsomal fractions were prepared from pooled tissues of 5 rats.

No remarkable differences were found between the three coumarin-treatments. In addition, one group of male Lewls rats received a single high dose of warfarin ( $\pm 6 \mathrm{mg} / \mathrm{rat}$, intraperitontally) and these rats were sacrificed 20 hours later. Except for prothrombin the coagulation factor activities in the plasma-samples of these rats were lower than in the chronic experiments.

Amounts of coumarin present in plasma and in the microsomal fractions of varlous organs.

The amounts of coumarins were determined in all plasma-samples and in the nicrosomal fractions of liver, kidney, lung, spleen, testis, heart, bratin and nuscle-tissue varied considerably. As is shown in table It, the plasma coumarin concentrations were different. The amount of acenocoumarol For instance is much lower than the anount of phenprocoumon, which on its 
turn is only about $25 \%$ of the warfarin concentration. These dissimilatitus are due to differences in the pharmacokinetics of the particular drugs $(15,16,17)$. In spite of the different plasma-concentrations no substantial differences were obserwed in the microsomal contents of the chree counarins (table II). In kidney, lung, spleen and testis microsomes, the coumarin contents were about equal, but at least five fold lower than in liver microsomes. An acute high dose of warfarin resulted in a lower warfartn concentration in liver microsomes than the chronic warfarin treatment did, while no differences were observed in the non-hepatic microsomal fractions. The coumarin concentrations in brain, muscle and heart microsomes were to low to quatify although low amounts of all three drugs could be demonstrated in the tissue homogenates.

The effects of different coumarin treatments on witamin $\mathrm{K}$ epoxide reductase activities

The reduction of vitam $K$ epoxide to vitamin $K$ quinone in liver has been shown to be inhibited in vivo by warfarin. Recently, this inhibition has also been demonstrated in rat kidney and testis microsomes. We have compared the effects of acenocoumarol, phenprocoumon and warfarintreatments with respect to the inhibition of vitamin $k$ epoxide reductase activities in liver, kidney, testis, lung, spleen, brain and muscle microsomes. In all thicrosomal preparations from normal rats vitamin $k$ epoxide reductase activity could be demonstrated, although the values measured for heart and muscle microsomes were very low (Lable III). Therefore it was not possible to determine accurately any inhibltion by coumarins in heart and muscle. Comparing the effects of the various drugs we must conclude that in all tissues phenprocoumon appeared to be slighty less inhibitory than acenocoumarol and warfarin (table rw). By each drug the non-hepatic vitamin $K$ epoxide reductases were all inhibited to a similar extent, while the hepatic enzyme was found to be clearly uore reduced. The acute high dose of watarin resulted in 10-20\% more inhibition than the chronic low-dose warfarin treatment did. Agatn, the liver reductase appeared to be more affected than the non-hepatic enzymes. 
Vitamin $x$ epoxide reductise activities in tissues of norma1 Lewis rats

tissue
(pmolain $k$ epoxitamin $K / m$ med per mg protein)

$\begin{array}{lc}\text { liver } & 28 \\ \text { kidney } & 15 \\ \text { tegtis } & 16 \\ \text { lung } & 7 \\ \text { splleen } & 5 \\ \text { britin } & 6 \\ \text { heart } & <0.5 \\ \text { muscle } & <0.5\end{array}$

Vitamin K-epoxide reductase actluttes were measured in micrasomal fractions of varlous tissues of non-treated rats. The data are the mean of duplicate measurements.

The effects of varlous coumarin treatments on the amounts of non-carboxylated precursor proteins

It has been demonstrated before, that as a result of warfarin treatment non-carboxylated precursor protelns (the so-called endogenous substrate for carboxylase) accunulate $\mathrm{In}$ both hepatic and non-hepatic tissues. The purpose of this experiment was to Investigate possible differences in the amounts of these endogenous substrates after different coumarin treatments. Ag is shown in table $V$ a chronic low dose treatment of elther acenocounarol, phenprocoumon or warfartn resulted in similar levels of endogenous substrate. In liver, the increase in endogenous substrate is at least tentold, in the other tissues this increase is less pronounced. In liver the chronlic low dose coumarin treatment resulted in a larger amount of endogenous substrate than the acute high dose of warfarin did. 
Table IV

Effects of acenocoumarol (A), phenprocoumon (P) and warfarin (W) treatment on vitamin $k$-epoxide reductase actiwity in various tissues

\begin{tabular}{|c|c|c|c|c|}
\hline \multirow[t]{3}{*}{ tissue } & \multicolumn{4}{|c|}{ vitamin $k$-epoxide reductase activity (\% of non-treated values) } \\
\hline & \multicolumn{3}{|c|}{7 days low-dose treatment } & \multirow{2}{*}{ single high dose } \\
\hline & A & $\mathrm{P}$ & W & \\
\hline liver & 30 & 36 & 33 & 23 \\
\hline kidney & 46 & 66 & 52 & 34 \\
\hline testis & 44 & 62 & 47 & 29 \\
\hline lung & 47 & 62 & 46 & 36 \\
\hline spleen & 45 & 59 & 52 & 32 \\
\hline brain & 46 & 66 & 51 & 38 \\
\hline
\end{tabular}

Vitamin $K$ epoxide reductase activities were measured in the microsoma fractions of various tissues of coumarin-treated rats. The data are the mean of duplicate measurements and are expressed as percentage of the corresponding activities in non-treated rats.

The effects of various coumarin treatments on vitamin $\mathrm{K}$-dependent carboxylase activities

The vitamin $\mathrm{K}$-dependent carboxylase activity was deternined in the microsomal fractions of the varlous tissues. From the data show in table VI, it will be clear that vitamin $K$-dependent carboxylase activity can be demonstrated in all. tissues examed, even in braln, heart and muscle, although the activities in the latter tissues are less than 10\% that la normal liver microsomes. The data obtalned in these experiments are in reasonable agreement with the findings of Buchtal and Bell (5). After the chronic low dose coumarin treatrents the vitamin $K$-dependent carboxylase activity in liver was increased. This effect has been shown before in hypothrombinemic rats $(18,19)$. The increase in carboxylase activity is, however, less pronounced or absent in the non-hepatic tissues. No signiflcant differences in vitamin $K$-dependent carboxylase activites were 
Table V

Effects of acenocoumarol (A), phenprocoumon (P) and warfarin (W) treatment on the amounts of non-carboxylated precursor proteins

\begin{tabular}{|c|c|c|c|c|c|}
\hline \multirow[t]{4}{*}{ thsue } & \multicolumn{5}{|c|}{ amount of non-carboxylated precursor proteins } \\
\hline & \multirow{3}{*}{$\begin{array}{c}\text { mormal } \\
(\text { dpa/mig protein) }\end{array}$} & \multirow{2}{*}{\multicolumn{3}{|c|}{$\begin{array}{c}\text { chronic low dose treatment } \\
(\% \text { of norma } 1)\end{array}$}} & \multirow{3}{*}{$\begin{array}{c}\text { single high dose } \\
(\% \text { of normel } 1) \\
W\end{array}$} \\
\hline & & & & & \\
\hline & & A. & $\mathrm{P}$ & $\mathrm{W}$ & \\
\hline 1. ver & 1.250 & 1.760 & 1640 & 1400 & 800 \\
\hline kidney & 480 & 230 & 215 & 270 & 150 \\
\hline testis & 200 & 130 & 145 & 215 & 140 \\
\hline lung & 375 & 1.50 & 190 & 170 & 190 \\
\hline spleen & 350 & 120 & 170 & 150 & 200 \\
\hline brain & 50 & 200 & 250 & 220 & 270 \\
\hline heart & 45 & 170 & 200 & 240 & 270 \\
\hline muscle & 65 & 1.50 & 170 & 200 & 200 \\
\hline
\end{tabular}

The amounts of non-carboxylated precursor proteins were measured in the microsomal fractions of varlous tissues. Values are expressed as dpm ${ }^{14} \mathrm{CO}_{2}$ incorporated per mg microsomal protein. Blank values, ranging between 10 and $30 \mathrm{dgrm}$ per $\mathrm{mg}$ microsomal protein were subtracted. The amounts of endogenous substrate found after coumarin treatments are presented as percentages of the content in the corresponding tissues of non-treated rats. The data are the mean of triplicate measurements.

found between acenocoumarol, phenprocoumon or warfarin treatment. The administration of an acute high dose of warfarin resulted in equal or slightly Increased vitamin $k$-dependent carboxylase activities as compared to normal values. The enhanced vitamin $K$ dependent carboxylase activity might elther be due to stabilisation of the enzyme by its endogenous substrate during isolation (18) or by changes in the quantity (de novo synthesis) or qualicy (enhanced enzymatic activity) of the enzyme, Induced during the hypocoagulability state of the animals. 
Table VI

Effects of acenocoumarol (A), phenprocoumon (P) and warfarin (W) treatments on vitamin $K$ dependent carboxylase activities in various tissues

\begin{tabular}{|c|c|c|c|c|c|}
\hline \multirow[t]{3}{*}{ rissue } & \multicolumn{5}{|c|}{ vitamin K-dependent carboxylase activity } \\
\hline & \multirow{2}{*}{$\begin{array}{c}\text { normal } \\
\text { (dpm/min per } \\
\text { mg protein) }\end{array}$} & \multicolumn{3}{|c|}{$\begin{array}{c}\text { chronlc low dose treatment } \\
(\% \text { of normal) }\end{array}$} & \multirow{2}{*}{$\begin{array}{c}\text { single bigh dose } \\
(\% \text { of normal) } \\
\mathrm{W}\end{array}$} \\
\hline & & A & $P$ & $W$ & \\
\hline liver & 3600 & 240 & 310 & 280 & 150 \\
\hline kidney & 680 & 125 & 120 & 135 & 110 \\
\hline testis & 3.40 & 125 & 150 & 200 & 190 \\
\hline 1 ung & 920 & 110 & 110 & 100 & 125 \\
\hline spleen & 460 & 105 & 110 & 140 & 160 \\
\hline brain & 220 & 120 & 160 & 145 & 190 \\
\hline heart & 100 & 140 & 200 & 180 & 225 \\
\hline muscle & 100 & 160 & 120 & 140 & 160 \\
\hline
\end{tabular}

Vitamin $\mathrm{K}$-dependent carboxylase activities were measured in the microspmal fractions of various tissues. Values are expressed as dpm ${ }^{14} \mathrm{CO}_{2}$ incorporated per min per mg microsomal protein. Blank values, ranging between 5 and $15 \mathrm{dpm}$ per tin per mg microsomal protein were subtracted. The activities found after coumarin treatments are presented as a percentage of the corresponding activities in normal rats. The data are the mean of triplicate measurements.

\section{DISCUSSION}

In this study we conflrmed that both vitanin k-epoxtde reductiste and vitamln $K$-dependent carboxylase are present in liver as well as in many non-hepatic tissues like kidney, $\mathbb{l}$ ung, spleen, testls and brain. Even la heart and muscle miscrosomes these enzymes were demonstrated although the measured activities were low. The concentrations of vitamin $K$ epoxtde reductase in liver which were found in our experiments are in good agreement with the results of wallin et al. (21), somewhat higher than 
those reported by Hildebrand et al. (22) and Thijssen et al and somewhat lower than the walues found by Fasco et al. (23). The reductase activities measured in kidney and testis microsomes were reasonably higher than previously reporced (8). These discrepancies may be explained by differences in the rat stralins used and in the methods of preparing the mierosomes and testing the activities.

No slgnificant differences were found between the effects of chronic treatments with ither acenocoumarol, phenprocoumon or warfarin: the clotting factor activities were all reduced to the same extent, the vitamin $K$ epoxide reductase activities had been comparably decreased and no differences were found in the accumulation of non-carboxylated precursor protelns. From these results it is suggested that the three coumarins act In a similar way. Although the plasma-concentrations of acenocoumaral, phenprocoumon or warfarin differed largely, these differences were not reflected in the microsomal coumarin contents. In hepatic microsomes, the coumarin content per ing microsomal protein was at least five fold higher than In non-hepatic fractions. This might be explained by the presence of more vitamin $\mathrm{K}$-dependent systens per mg microsomal protein. However, a correlation between vitamin $K$ epoxide reductase activity and microsomal coumarin concentration was not observed. The effects of the coumarins are obviously more pronounced in liver than in non-hepatic tissues. The hepatic vitamin $K$ epoxide reductase activities for instance appeared to be clearly more reduced than the non-hepatic enzymes. These findings support the data from recent pharmacokinetic experiments with $S$-warfarin supplied by osmotic minlpumps for 3 days (8). Furthermore, a largely increased amount of non-carboxylated hepatic precursor proteins was measured, while this increase was conslderable lower for the non-hepatic precursor proteins. No correlation was found between the amount of the endogenous substrate and the percentage of inhibition of the vitamin $k$ epoxide reductase. However, the posslbility that non-carboxylated precursor proteins from non-hepatic origin are more easily excreted than the hepatic ones cannot be ruled out.

In an earlier study we reported a greater increase of endogenous substrate for: carboxylase in lung, spleen and testis microsomes after 7 days of low dose warfarlin treatment. Apart from individual rat differences, this apparent discrepancy between the data may be explained by the fact 
that we now use a slightly different and more sensituve test. In former experiments we used to subtract as blank values the amount of ${ }^{14} \mathrm{CO}_{2}$ incorporated in incubation mixtures in the absence of added vitamin $K$ hydroquinone. However, there is still a small anount of endogenous vitamin $K$ quinone present in microsomes (unpublished data). By adding dithiothreltol to the incubation mixture the quinone is reduced in vitro to hydroquinone and used as a cofactor for carboxylation. Incubations in the absence of both vitamin $\mathrm{K}$ hydroquinone and dithiothreitol result in lower amounts of incorporated ${ }^{14} \mathrm{CO}_{2}$ then the formerly used blank incubations. Therefore a higher amount of non-carboxylated precursors is detected now in the microsomal fraction of normal animals.

The acute high dose of warfarin resulted in warfarin contents in the non-hepatic microsomal fractions similar to those elicited by the chronic low dose treatment. On the contrary, in liver microsomes, the coumarin content was $\pm 60 \%$ of the amount after chronic treatment. Vitamin $k$ epoxtde reductase activities were $10-20 \%$ lower than after the chronic warfartn treatment. In the liver the latter treatment resulted in the accumulation of about twice as much endogenous substrate than after the acute high dose of warfarin. This may be explained by the fact that the time elapsed between the acute blockade of the vitamin k-cycle (inhibition of vitamin $k$ quinone reductase and vitamin $K$ epoxide reductase) and sacrifice of the rats is too short to reach a steady state between synthests and excretion of the precursor-proteins in liver.

In some studles a vitamin $K$ deficlent det ls preferably used lingtead of an acute dose of warfarin because the diet is thought to result in a higher wtamin K-dependent carboxylase enzymatic activity in liver microsomes. As a vitamin $K$-deficient dlet is rather expensive, a prolonged treatment of rats with a low dose of warfarin in the drinking water might be a good alternative.

Our results may have relevance for the application of coumarln anticoagulant therapy in man. It might be expected that hardly any differences will be observed in the effects on vitamin $K$-dependent enzymes after elther acenocoumarol, phenprocoumon or warfarin treatment. In addjtion tt might be expected that the non-hepatic vitamin K-dependent enzymes will be also inhibited, although to a lesser extent than the hepatic ones. To confirm 
these regults in human vitamin $K$-dependent systems, investigations are now in current progress $\mathbb{1 n}$ our institute.

\section{Acknowledgements}

The authors wh to thank Dr. H.C. Hemker for his stimulating discusstons, Mrs. A.D. Muller for perforning the coagulation tests, F.H. Weekers and G.M.J. Janssen for their skilful technical assistance and Mrs. M. Molenat-v.d. Woort for typing this manuscript. This research was 3upported by grant MO 82145 from the Trombosestichting Nederland.

\section{REERRENCES}

1. Suttle, J.W. Ann. Rev. Blochem. 54:459-477, 1984

2. 01son, R.E. Ann. Rev. of Nutr. 4:281-337, 1984

3. Vermeer, C, and De Boer-van den Berg, M.A.G. Haematologila 18: 71-97, 1985

4. Vermeer, C., Hendrix, H. and Daemen, M. FEBS Lett. 148: 317-320, 1985

5. Buchtal, S.D. and Bel1, R.G. BLochernfstry 22: 1077-1082, 1983

6. Vermeer, C., Soute, B.A.M., Ulrich, M.M.W., Hanulyäk, K. and De Boer-van den Berg, M.A.G. Blochem. Soc. Transact. 12:922-924, 1984

7. Roncagliont, M.G., Soute, B.A.M., De Boer-van den Berg, M.A.G. and Vermeer, C. Biochem. Biophys. Res. Commun. 114: 99l-997, 1983

8. Thijssen, H.H.W., Janssen, C.A.T. and Drttty-Reijnders, M.J. J. Blochem. Pharmacol. 35: 3277-3282, 1986

9. Vermeer, C., Soute, B.A.M., De Metz, M. and Hemker, H.C. Biochin. Biophys. Acta 714: $361-365,1982$

10. Tishler, M., Fieser, L.Ë. and Wendler, N.L. J* Am. 0il Chem. Soc. 62: $2866-2871,1940$

11. Van Dam-Mieras, M.C.E., Muller, A.D., Van Dieiljen, G. and Hemker, H.C. In: Methods of Enzymatic Analysis (Bergmeljer H.U., Bergmeljer, J. and Grassi, M. eds.) pp. 352-394 Verlag chemle, D-6940, Weinhein, 1984

12. De Metz, M., Vermeer, C., Soute, B.A.M. and Hemker, H.C. In "Vitamin K metabolisin and vitamin k-dependent protein (Suttie, J.W. ed) pp 560-570. Unlversity park Press, Baltimore, 1980

13. Sedmak, J.J. and Grosisberg, S.E. Anal. BLochem. 79: 544-552, 1977

14. Thijssen, H.H.W., Baars, L.G. and Reijnders, M.J. J.Chromatogr. 274: $231-238,1984$

15. Thijssen, H.H.W., Baars, L.G. and Reijnders, M.J. J. Pharm. Pharmacol. 35: $793-798,1983$

16. Yacobl, A. and Levy, G. J. Pharmacok. Blopharm. 2: 239-255, 1984

17. Schmidt, W., Trenk, n. and Jähnehen, E. Pharmacol. 21: 313-322, 1980

18. Shah, D.V. and Suttie, J.W. Arch. Biochen. Biophys. 191: 571-577, 1978

19. Rikong-Adie, H., Decottignies-le MarEchal, P. Azerad, R. and Marquet, A.: In Vitamin $K$ metabolism and Vitamin $K$-dependent protein (Suttie, J.W. ed) pp 518-526. University Park Press, Baitimore, 1979

20. Shah, D.V., Swanson, J.C. and Suttie, J.W. Arch. Biochem. Biophys. 222: $216-221,1983$ 
21. Wallin, R. and Martin, L.F. J. Clin. Invest. 1879-1884, 1985

22. Hildebrandt, E.F., Preusch, PuC., Patterson, J.L. and Suttie, J.W. Arch. Bilochem. Biophys. 228: $480-492,1984$

23. Fasco, M.J., Preusch, P.C., Hildebrandt, E. and Suttie, J.H. J. Biol. Chem. 258: 4372-4380, 1983 



\section{DECARBOXYLATED BONE GLA-PROTEIN AS A SUBSTRATE FOR HEPATIC VITAMIN K-DEPENDENT CARBOXYLASE}

C. Vermeer, B.A.M. Soute, H. Hendrix and M.A.G. de Boer-van den Berg

\section{STJMMARY}

Bovine Bone Gla-Protein (B.G.P.) was prepared and decarboxylated into descarboxy-B.G.P. (d-B.G.P.). The latter was purtfled and identified as decarboxylated osteocalcin. Both crude and purifled d-B.G.P. are good substrates for vitamin $K$-dependent carboxylase. Because the $K_{M}$ of this enzyme for d-B.G.P. is low, the latter is a better substrate than the frequently used pentapeptide F L E E L or exogenous proteln substrates such as descarboxyprothrombin. 
INTRODUCTION

Witam $K$-dependent carboxylase has been detected in the 1iver $(1,2)$ and in many other mamalian tissues $(3,4)$. It is involved in the postranslational carboxylation of glutamic acid (GIu) residues into 4-carboxyglutanic acid (Gla) residues (5). Except for the vitamin K-dependent coagulation factors, the function of these Gla-containing proteins is not completely understood, but it is generally believed that in all cases the Gla-residues are required for the binding of $\mathrm{Ca}^{2+}$.

Although much work has been done already to elucidate the mechanism of the vitamin K-dependent reaction, the latter is still a matter of debate $(6,7)$. In mast expertments concerning this subject the synthetic pentapeptide Phe-Leu-GLu-Glu-Leu (F L E E L) is used as an exogenous substrate for carboxylase. Because of its low molecular weight this peptide can be added to catboxylase in high concentrations (20-20 m). Disadvantages are, however, that it has a high $K_{M}(4-6 \mathrm{mM})$ for carboxylase $(8,9)$ and that it is extremely expensive. Until now only one exogenous substrate has been described with a low $k_{M}$ for carboxylase: Fragment $S u$, a peptide which is obtained after proteolytical degradation of descarboxyprothrombin with subtilisin and which corresponds to the ardnoacids 13-29 in descarboxyprothrombin (9). This substrate, however, is not comercially available and its preparation is both expensive and labortous.

We describe here the preparation of another exogenous substrate for carboxylase. It combines the advantage of a low $\mathrm{K}_{\mathrm{M}}$ for carboxylase with the fact that it is readily prepared in large quantities at a low cost.

\section{MATERIALS AND METHODS}

\section{Chemicals:}

Whamin $\mathrm{K}_{1}$ (Konakion ${ }^{\mathrm{R}}$ ) was obtained from Hoffmann-La Roche and vitamin $\mathrm{K}$ bydroquinone was prepared as in (10). Dithiothreftol (DTT), benzamidine, aprotinin and 3-([3-cholamidopropyl]dimethylammoniol)-1-propane sulfomate (CHAPS) were from Sigma and the pentapeptide Phe-Leu-Glu-Glu-Leu(F L E E L) from Vega Fox. $\mathrm{NaH}^{14} \mathrm{CO}_{3}(40-60 \mathrm{Ci} /$ mol $)$ was purchased from Anersham and Sephadex G-25 from Pharmacia. All other chemicals were obtained from Merck. 


\section{Preparation of decarboxylated Bone Gla-Proteln.}

Fresh bovine femurs and tibias were obtained from the Mastricht slaughter House, cut into slices and demarrowed. The bones were carefully cleaned, heated at $120^{\circ} \mathrm{C}$ overmight and ground to powder mechanically. Powder (100 g) was extracted by stirring overnight with 200 ml of buffer A (1. M EDTA, $0.2 \mathrm{M} \mathrm{KCl}, 0.1 \mathrm{M}$ benzamidine, $\mathrm{pH}$ 8.0). Insoluble material was removed by filtration and the solution was desalted on a Sephadex $6-25$ colutun (60x5 $\mathrm{cm}$ ) in water. The protein peak was collected and the pH was adjusted to 2.5 by adding $1 \mathrm{M} \mathrm{HCl}$. The preparation was subsequently lyophllyzed and decarboxylated by heating at $110^{\circ} \mathrm{C}$ for 5 h under vacuum (11). The resulting material was dissolved in buffer $\mathrm{B}(0.1 \mathrm{M} \mathrm{KCl}, 0.02 \mathrm{M} \mathrm{Tris-HC1}$, pH 7.4) to a final concentration of $5 \mathrm{mg} / \mathrm{ml}$. Since after the decarboxylation step the proteins remain acidic, it is important that the pH of the solution is checked at this stage. The preparation thus obtained is referred to as crude decarboxylated Bone Gla-Protein (d-B.G.P.).

\section{Various Assays}

Vitamin K-dependent carboxylase was prepared from normal cow tissues (3) and carboxylase activity was measured by the incorporation of ${ }^{14} \mathrm{CO}_{2}$ into exogenous substrates in the presence of vitamin $K$ hydroquinone (10). High performance liquid chromatography (HPLC) was carried out using a Beckmann-112 system and a Mono Q collum (Pharmacia) for anion exchange chromatography and a Spherogel-TSK $2000 \mathrm{SW}$ column (Beckmann, $300 \times 7.5 \mathrm{~mm}$ ) as a molecular sieve. Protein concentrations were determined according to Lowry (12) and the N-terminal aminoacld was identifled as described by Welner et al. (13). Gla and Glu restdues were determined by alkallne hydrolysis of the protein and subsequent MPLC on a Nucleosil 5 SB colum (Chrompack) according to the method of Kuwada and Katayama (14).

\section{RESULTS}

During the preparation of Bone Gla-protein (B.G.P.) It turned out that the bone powder could be extracted a number of times and that after each extraction about $70 \mathrm{mg}$ of protein was present in the extract. Five subsequent extracts obtained from one portion of $100 \mathrm{~g}$ bone powder were separately processed for the production of d-B.G.P. The Gla/Glu ratio in 


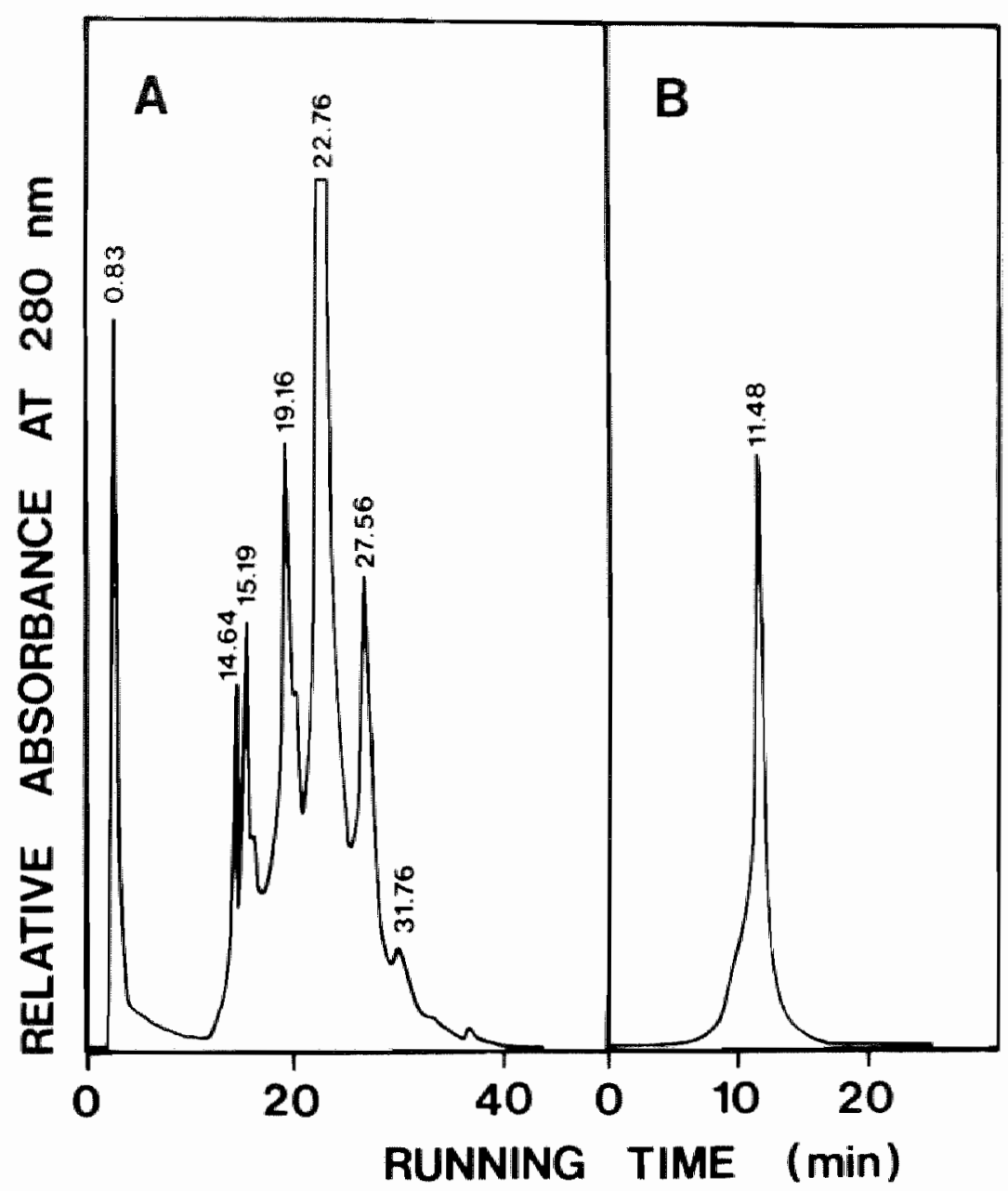

Fig. 1. Fractionation of d-B.G.P.

A: one mg of crude d-G.B.P. was adsorbed to a Mono $Q$ ion exchange colum and eluted with a linear aat gradient from 0.05 to $0.5 \mathrm{M}$ NaCl in $20 \mathrm{mM}$ Tris-HCl, $\mathrm{pH}$ 7.4. The eluate was recorded at $280 \mathrm{~mm}$ and the start of the tracing represents the start of the gradient. The various peaks were collected and tested with the carbaxylase asaay. All d-B.G.P. activity was recovered in the peak eluting after $22.76 \mathrm{~min}$.

B: the eluted d-B.G.P. Was analyzed on a TSK-2000 motecular aieve and all activity was recovered in the peak eluting after $11.48 \mathrm{~min}$. Trasylot eluted after $11.56 \mathrm{~min}$. 
these extracts was 0.03 before and 0 after decarboxylation. The decarboxylated preparations were used as substrates for carboxylase and in all cases the incorporation of ${ }^{14} \mathrm{CO}_{2}$ amounted about $120000 \mathrm{dpm}$ per ang of substrate after an incubation of 3 h at $25^{\circ} \mathrm{C}$ under standard conditions. Since no differences were found between the various preparations they were pooled and used for the purification of $d-B . G . P$.

The crude d-B.G.P. Was purified by HPLC on an ion exchange colum (fig. 1A). When analyzed on a size exclusion column the preparation thus obtained eluted in a single peak (Eig. 1B) shortly before trasylol (aprotinin), and its apparent molecular weight was about 6800 ; the $\mathrm{NH}_{2}$-terminal amino-acid was identified as tyrosine. Since similar characteristics have been reported for bovine osteocalcin $(15,16)$ it is highly probable that $\mathbb{A}-B \cdot G$.P. is similar to decarboxylated osteocalcin. The optimal reaction condtions for the carboxylation of d-B.G.P. Were compared with those for the carboxylation of F L E E L and it turned out that they were simllar for both substrates. Therefore the following conditions were used in all experiments described below: $0.25 \mathrm{ml}$ reaction mixtures containing $4 \mathrm{mg}$ of microsomal proteins, $0.4 \mathrm{M} \mathrm{KCl}, 0.05 \mathrm{M} \mathrm{Tr} \mathrm{Ts}-\mathrm{HCl}, \mathrm{pH} 7.4,0.4 \%$ CHAPS, $12 \%$ ethylene glycol, $16 \mathrm{mM}$ DTT, $0.1 \mathrm{mM}$ vitamin $\mathrm{K}$ hydroquinone and $0.01 \mathrm{mCl}$ $\mathrm{NaH}^{14} \mathrm{CO}_{3}$ were incubated at $25^{\circ} \mathrm{C}$. Under these conditions the carboxylation of both substrates was markedly enhanced by the addition of $\left(\mathrm{NH}_{4}\right)_{2} \mathrm{SO}_{4}$. Unless stated otherwise we therefore added $\left(\mathrm{NH}_{4}\right)_{2} \mathrm{SO}_{4}$ to our reaction mixtures to a final concentration of $1 \mathrm{M}$.

When we compared the kinetic constants of the two substrates we found the $K_{M}$ of $F$ L E E L to be $4.8 \mathrm{mM}$ and that of d-B.G.P. $0.025 \mathrm{mM}$. The respective maximal reaction rates $\left(V_{\text {max }}\right)$ were 14375 and $4825 \mathrm{dpm} / \mathrm{min}$. It was checked that the presence of $\left(\mathrm{NH}_{4}\right)_{2} \mathrm{SO}_{4}$ did not affect the $\mathrm{K}_{\mathrm{M}}$ of the two substrates but only increased the $V_{\text {max }}$. The fact that the $V_{\text {max }}$ of $F L E E L$ is higher than that of $d-B . P . G$. probably results from its low molecular weight, which will be accompanied by a high diffusion rate.

Time courses of the carboxylation of the two substrates (both, in the presence and absence of $\left.\left(\mathrm{NH}_{4}\right)_{2} \mathrm{SO}_{4}\right)$ are show in $\mathrm{fig} .2$ and it is clear that $\left(\mathrm{NH}_{4}\right)_{2} \mathrm{SO}_{4}$ not only increases the initial carboxylation rate 4-5-fold, but that also at the end point of the reaction (after $4 \mathrm{~h}$ ) the amounts of incorporated ${ }^{14} \mathrm{CO}_{2}$ are five times higher in the presence of $\left(\mathrm{NH}_{4}\right)_{2} \mathrm{SO}_{4}$ than in its absence. Hence $\left(\mathrm{NH}_{4}\right)_{2} \mathrm{SO}_{4}$ induces an lncrease of the total amount of 


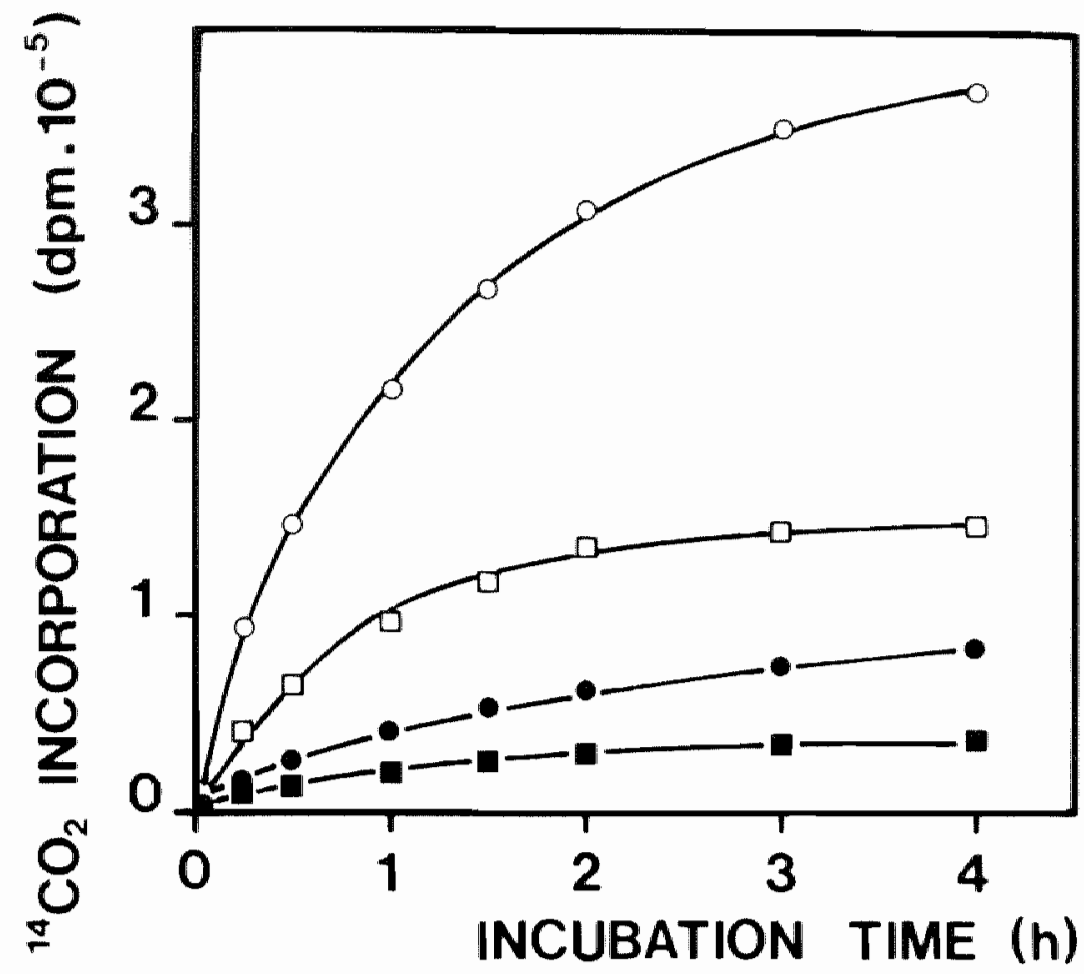

Fig. 2. Bffeat of (NH $)_{2} \mathrm{SO}_{4}$ on the carboxylation of $d-B . G . P$. and $F L E E L$. The carboxylation of both aubstrates was montitored after several intervals of time in the preaence and absence of $1 \mathrm{M}\left(\mathrm{NH}_{4}\right)_{2} \mathrm{SO}_{4}$ : $(0-0), F L E E L(4 \mathrm{mM}) ;(\mathrm{O}-\mathrm{O}), F L E E L(4 \mathrm{mM})+\left(\mathrm{NH}_{4}^{4}\right)_{2}^{2} \mathrm{SO}_{4}^{4} ;$

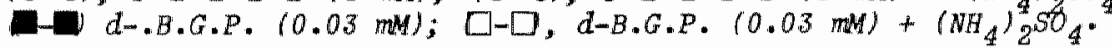

carboxylation events that can be accomplished under our experimental conditions. From these type of experiments we have calculated the efficiency of the carboxylation reaction and it turned out that at limiting substrate concentrations 0.008 mole of $\mathrm{CO}_{2}$ is bound per mole of F LEE L. For d-B.G.P. this value is 0.16 . 


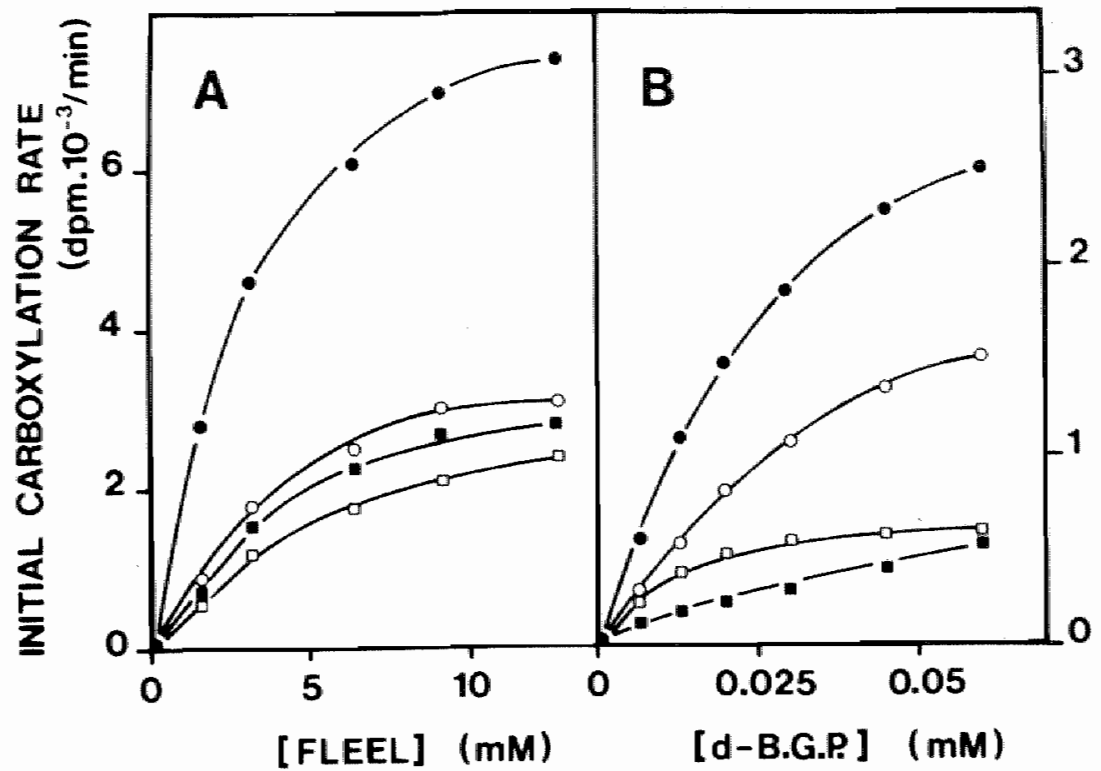

Fig. 3. The carboxylation of $F L E E L$ and d-B.G.P. in various carboxylating systems.

The initial reaction rate was meabured for the carboxylation of $F L E E L(10 \mathrm{mM}, A)$ and d-B.G.P. (0.05 mM, B). The incubatione were performed in standard reaction mixtures containing $1 \mathrm{M}$ $\left(\mathrm{NH}_{4}\right)_{2} \mathrm{SO}_{4}$. The sources of carboxylase were bovine liver (-), kidney (O-O), testis $(\square-\mathrm{C})$ and aorta $(\square-\square)$. Note the different scales for $A$ and $B$.

We have also checked whether d-B.G.P. Is carboxylated in non-hepatic systems. In fig. 3 the carboxylation of $F L E \mathbb{L}$ and that of $\mathbb{A}-\mathbb{B} . G . P$. are compared in carboxylating systems from 11ver, kidney, testis and aorta and it is clear that both substrates are carboxylated in all systems.

It should be noted that most of the carboxylation reactions described above (except the determination of the kinetic constants) were performed both, with purified and with crude d-B.G.P. In none of these experiments we have detected any difference between crude and purifled d-B.G.P. This demonitrates that the contaminating proteins in crude d-B.G.P. do not influence the carboxylation reaction, so that in most cases no further purification of the substrate is required. 
DISCUSSION

The frst exogenous substrate for vitanin $k$-dependent carboxylase that has been described in the 1iterature is the synthetic pentapeptide FLEEL (17). Since it has been derived from an aminoacid sequence in prothrombin It may be regarded as a homologous substrate for hepatic carboxylase (prothrombin 18 synthesized in the 11ver) but it is also readily carboxylated in non-hepatic systems (3). Although FLEEL has proven to be very helpful in investigatlons concerning vaxious carboxylating enzyme systems, its main disadvantages are that 1 it is expensive and that it has a high $K_{M}$ for carboxylase. To overcome at least this last drawback, derivatives of FLEEL as well as other Glu-containing peptides have been synthesized (18). Unfortunately none of these substrates proved to be a better substrate than FLEEL is.

Unt1l now the only known exogenous substrate with a low $\mathrm{K}_{\mathrm{M}}$ for carboxylase was Fragment $\mathrm{Su}$, a Glu-contalning peptide which is obtained from descarboxyprothrombin by proteolytic cleavage with subtilisin (9). Unfortunately $t$ ts preparation is both laborious and expensive and $1 t$ is not commerclally avallable.

We have described here the preparation of a protein from bovine bone whilch, in its decarboxylated form, may serve as a substrate for both hepatic as well as varlous non-hepatic carboxylases. The protein could be identifled as osteacalcin and its $\mathrm{K}_{\mathrm{M}}$ for hepatic carboxylase was more than 200-fold lower than that of FLEEL. Osteocalcin, however, is synthesized in bone cells (19) and therefore it is the first exogenous substrate described to be well carboxylated in a heterologous system. The preparation procedure for the crude bone extract is quick, easy and cheap and since crude d-B.G.P. When used as a substrate for carboxylase- has the same characteristics as the purified material, in most cases it will not be necessary to purify the material further.

We have compared the optimal reaction conditions for the carboxylation of FLEEL and d-B.G.P. and no differences were found. Also the addition of $\left(\mathrm{NH}_{4}\right)_{2} \mathrm{SO}_{4}$ to the reaction mixtures stimulated the carboxylation of both substrates to the same extent. Therefore we recommend the use of d-B.G.P. as a substrate for vitamln $\mathrm{K}$-dependent carboxylase. 


\section{Acknowledgments}

This research was supported in part by grand MD 82145 from the Thrombosestichting Nederland. The authors wish to thank Dr. H.C. Hemker for his suggestions and stimulating discussions, Mr. J.E. Aerts for deglgning and constructing the bone mill and Mrs. M. Molenaar-van de Woort for typing this manuscript.

\section{REFERENCES}

1. Esmon, C.T., Sadowski, J.A. and Suttie, J.W. J. Biol. Chem. 250: $4744-4748,1975$

2. De Metz, M., Vermeer, C., Soute, B.A.M., van Scharrenburg, G.I.M., Slotboom, A.J. and Hemker, H.C. FEBS Lett. 123: 215-218, 1981

3. Vermeer, C., Hendrix, H. and Daemen, M. FEBS Lett. 148: 317-320, 1983

4. Buchtha1, S.D. and Be11, R.G. Biochemistry 22: 1077-1082, 1983

5. Stenflo, J. and Suttie, J.W. Ann. Rev. Biochem. 46: 157-172, 1977

6. Larson, A.E., Friedman, P.A. and Suttie, J.W. J. Biol. Chem. 256: $11032-11035,1981$

7. De Metz, M., Soute, B.A.M., Henker, H.C., Fokkens, R., Lugtenburg, J. and Vermeer, C. J. Biol. Chem. 257: 5413-5416, 1982

8. Canfield, L.M., Sinsky, T.A. and Suttie, J.W. Arch. Biochem. Blophys. 202: $515-524,1980$

9. Soute, B.A.M., Vermeer, C., de Metz, M*, Hemker, H.C. and Lijnen, H.R. Biachim. Blophys. Acta 676: 101-107, 1981

10. De Metz, M., Soute, B.A.M., Hemker, H.C. and Vermeer, C. Biochem. J. 209: $719-724,1983$

11. Poser, J.W. and Price, P.A. J. Biol. Chem. 254: 431-436, 1979

12. Lowry, O.H., Rosebrough, N.J., Farr, A.L. and Randall, R.J. J. Blol. Chem. 193: 265-275, 1951

13. Weiner, A.M., Platt, T. and Weber, K. J. Biol. Chem. 247: 3242-3251, 1972

14. Kuwada, M. and Katayama, K. Ana1. Biochem. 131: 173-179, 1983

15. Price, P.A., Otsuka, A.S., Poser, J.W., Kristaponis, J. and Raman, N. Proc. Natl. Acad. Scl USA 73: 1447-1451, 1976

16. Poser, J.W., Esch, F.S., Long, N.C. and Price, P.A. J. Btol. Chem. 255: $8685-8691,1980$

17. Suttie, J.W., Hageman, J.M., Lehrman, S.R. and Rfch, D.H. J. Biol. Chem. 251: 5827-5830, 1976

18. Rich, D.H., Lehrman, S.R., Kawa1, M., Goodman, H.L. and Suttle, J.W. J. Med. Chem. 24:706-711, 1981

19. Nishimoto, S.K. and Price, P.A. J. Biol. Chem. 254: 437-441, 1979 

DISCOVERT OF A 4-CARBOXYGLUTAMIC ACID-CONTAINING PROTEIN IN HUMAN SPERMATOZOA

\author{
B.A.M. Soute, W. Muller-Esterl, M.A.G. de Boer-van den Berg, \\ M.M.W. U1rich and C. Vermeer
}

\title{
SUMMARY
}

In this paper we describe the ddentiftcation of a 4 -carboxyglutamic acid-containing protein in human spermatozoa. After thermal decarboxylation the protein is a good substrate for vitamin $K$-dependent carboxylase from various origins. A quick puriflcation procedure for the decarboxylated protelin is presented and in a preliminar characterization we have established its molecular welght $(28000-30000)$ and 1 tes amino actd. composition. 
INTRODUCTION

Vitamin $K$-dependent carboxylase has been demonstrated in liver as well as in a nuber of non-hepatic tissues $(1,2)$. The enzyme system is involved in the conversion of glutanic acid (Glu) residues into 4-carboxyglutamic acid (Gla) residues and hence carboxylase-containing tissues are expected to be involved in the synthesis of Gla-containing proteins. Whereas the hepatic Gla-contalning protelns have been well identified ( 3 ), the nature of the non-hepatic ones is less clear. Since relatively high amounts of carboxylase dere found in testes, it seemed plausible that one or more Gla-contalining proteins are present in sperm. Indeed we have found such a proteln and its purlfication and preliminar characterization are reported in this paper.

\section{MATERIALS AND METHODS}

\section{Chemicals.}

Vitamin $k_{1}$ was obtained from Hoffmann-La Roche and vitamin $k$ hydroguinone was prepared as described earlier (4). Dithiothrettol benzamidine and 3-([3-cholamidopropy1]dimethylammonio)-1-propanesulfonate (CHAPS) were from Sigma and the pentapeptide Phe-Leu-Glu-Glu-Leu (F L E E L) was from Vega Biachemicals. NaH ${ }^{14} \mathrm{CO}_{3}(40-60 \mathrm{Ci} / \mathrm{mol})$ was purchased from Amersham * $\mathrm{QAE}-$ Sephadex, and the molecular weight marker proteins were from Pharmacia Fine Chemicals. All other chemicals were from Merck.

Preparation of crude sperm Gla-protein.

Fresh human sperm was collected from healthy donors and diluted 10 fold with a buffer contalning $0.25 \mathrm{M}$ sucrose, $0.10 \mathrm{M} \mathrm{NaCl}$ and $0.05 \mathrm{M} \mathrm{Tris-HCl}$, pH 8.0. Sperm count and sperm quality were checked routinely and they were within the normal range. The spernatozod were sedimented by centrifugation for 15 minutes at $600 \mathrm{~g}$ and $0^{\circ} \mathrm{C}$ and homogenized in a buffer containing 10 mM benzantidine, $0.5 \mathrm{M} \mathrm{KCl}$ and $50 \mathrm{mM}$ EDTA, pH 8.0. The suspension was subsequentiy centrifuged for $1 \mathrm{~h}$ at $100000 \mathrm{~g}$ and the supernatant was removed, diluted 5-fold with distilled water and extracted batchwise with QAE-Sephadex ( 1 ml of slurry per $100 \mathrm{ml}$ of diluted supernatant). The Sephadex was washed with $0.1 \mathrm{M} \mathrm{NaCl}$ in $0.01 \mathrm{M} \mathrm{Tris-HCI} \mathrm{(pH} \mathrm{7.4)} \mathrm{and} \mathrm{the}$ sperm Gla-protein was eluted with $1 \mathrm{M} N \mathrm{NaCl}$. The preparation was subsequent- 
ly desalted by size-exclusion chromatography on a Sephadex G-25 column in water, brought to $\mathrm{pH} 2.0$ with $1 \mathrm{M} \mathrm{HCl}$ and lyophilized. In some cases the lyophilized material was decarboxylated by heating at $110^{\circ} \mathrm{C}$ for $24 \mathrm{~h}$ ( ( 5 ). Purification of decarboxylated sperm Gla-protein.

Decarboxylated Sperm Gla-protein (d-S.G.P.) was purified from the lyophilized material by high performance liquid chromatography (HPLC) using a Beckman 112 gradient system. The first purification step was on a mono-Q anion-exchange colum (Pharmacia, $50 \times 5 \mathrm{~mm}$ ). The lyophilized proteins (20 $\mathrm{mg}$ ) were dissolved in a $0.02 \mathrm{M}$ Tris-HCl buffer ( $\mathrm{pH}$ 8.5) containing $0.1 \mathrm{M}$ KC1 (buffer A), adsorbed on the ion-exchange gel in the same buffer, and then eluted with a linear gradient from 0.1 to $1 \mathrm{M} \mathrm{KC1}$ in $20 \mathrm{mM}$ Tris-HCl, $\mathrm{pH} 8.5$ at room temperature. The flow rate was adjusted to $60 \mathrm{ml} / \mathrm{h}$, the absorbance was monitored at $229 \mathrm{~nm}$, and fractions of $0.5 \mathrm{ml}$ were collected. The presence of d-S.G.P. In the various fractions was determined by incubating $0.1 \mathrm{ml}$ alliquots ia carboxylating reaction mixtures ( $0.25 \mathrm{ml})$ containlng microsomes from normal bovine liver (see below). The amount of ${ }^{14} \mathrm{CO}_{2}$ incorporated into the exogenous substrate was taken as a measure for the amount of d-S.G.P. present in the fractions. The peak fractions were paoled, concentrated and purified further on a TSK-3000 SW size-excluston column (Beckman, $300 \times 7.5 \mathrm{~mm}$ ) in buffer $\mathrm{A}$.

\section{Various assays.}

The vitamin $\mathrm{K}$-dependent incorporation of ${ }^{14} \mathrm{CO}_{2}$ was measured by incubating reaction mixtures $(0.25 \mathrm{ml})$ containing $4 \mathrm{mg}$ of microsomal protein, $0.15 \mathrm{M}$ $\mathrm{KCl}, 1 \mathrm{M}\left(\mathrm{NH}_{4}\right)_{2} \mathrm{SO}_{4}, 20 \mathrm{mM} \operatorname{Tris}-\mathrm{HCl}, \mathrm{pH} 7.5,10 \mathrm{mM}$ dtehiothre1tol, $0.4 \mathrm{mM}$ vitamin $K$ hydroquinone, $0.4 \%(w / v)$ CHAPS, $12 \%(v / v)$ ethylene glycol, 0.01 mCl $\mathrm{NaH}^{14} \mathrm{CO}_{3}$ and exogenous substrate as indicated. After 1 h at $25{ }^{\circ} \mathrm{C} 1 \mathrm{ml}$ of $5 \%(w / v)$ trichloroacetic acid was added to the mixtures, which were than bolled for 1 min and counted in Atomlight (NEN).

Protein-bound Gla-residues were determined after alkallne hydrolysis of the proteins and analysis of the hydrolysate on a Nucleosil 5-SB column (Chrompack $250 \times 4.6 \mathrm{~mm}$ ) as described by Kuwada and Katayama (6). Polyacrylamide gel electrophoresis was performed in slab gels as described by Laemmli (7) and protein concentrations were measured according to Lowry (8). Amino actd analysis was performed on an LKB 4400 Analyzer fitted with a $4.6 \times 200 \mathrm{~m}$ stainless steel column packed with ultropac 8 cation exchange resin. The column was eluted with lithium-containing buffers according to the manufacturer's prescriptions. 
RESULTS

Fresh human sperm was separated into spermatozoa and seminal plasma and the sperif cells were extracted with $50 \mathrm{mM} \mathrm{EDTA}$ in $0.5 \mathrm{M} \mathrm{KCl}$. After alkaline hydrolysis. Gla cauld be directly identified in the crude sperm cell

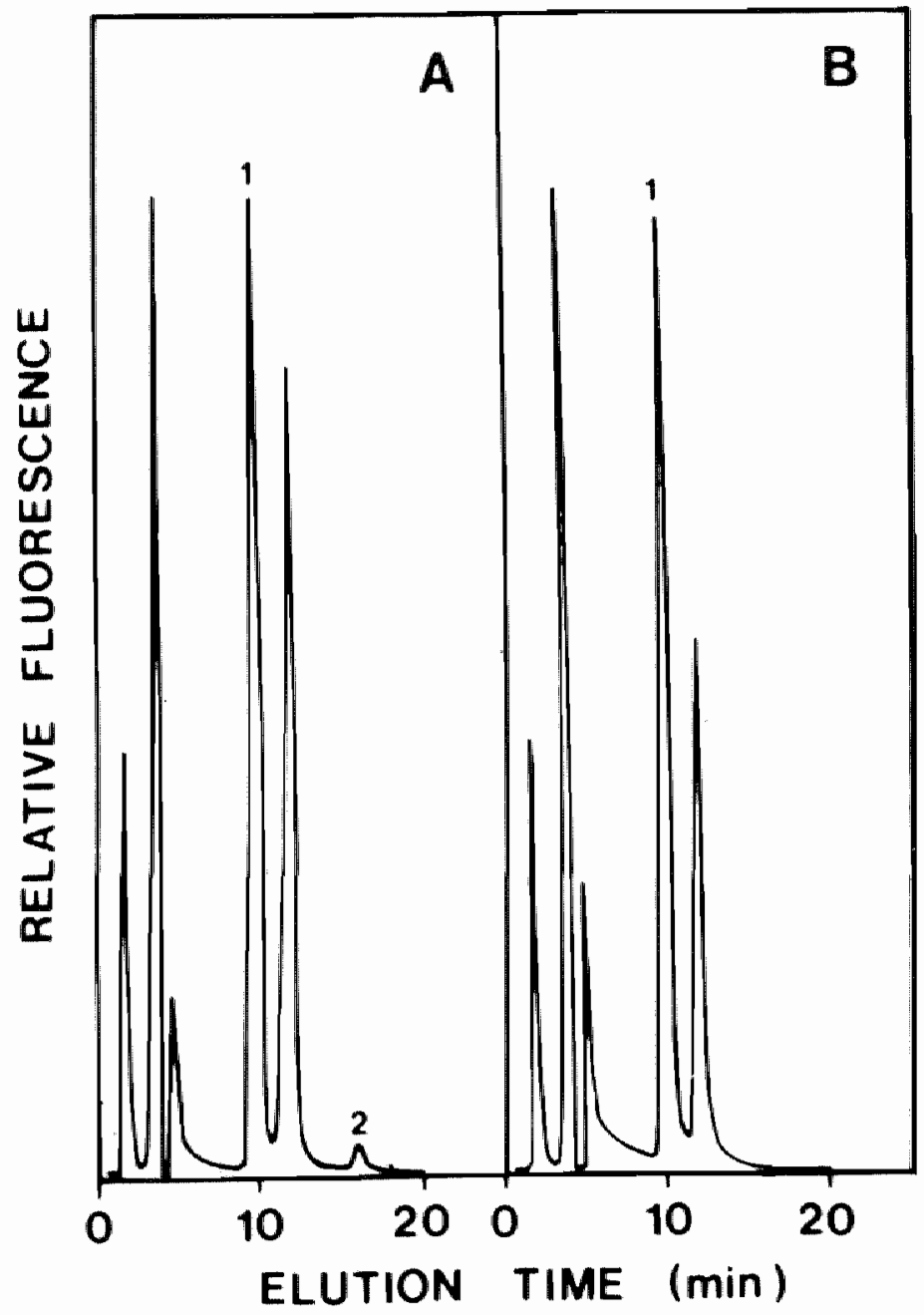

Fig. 1 .

4-carboxyglutamic acta detemination in spem celt protein

The presence of 4-carboxyglutamic acid (Gla) was established in alkaline hydrotysates of a crude cell extract before (panel A) and after (panel B) thermal decarbaxylation of the protein. The GLa-detemination was performed by HPLC analysis as described in Methods. Peaks 1 are Glu and peak 2 is Gta. 
extract (fig. IA). Although varying amounts of $\mathrm{Gla}(10-30 \%)$ were also found in the seminal plasma, we have focussed our attention on the Gla-containing protein derived from the spermatozoa. When the crude sperm cell extract mentioned above was submitted to thermal decarboxylation, the Gla-residues were readily converted inco Glu (fig. IB). A second observation was that in contrast to the starting material - the decarboxylated sperm Gla-protein

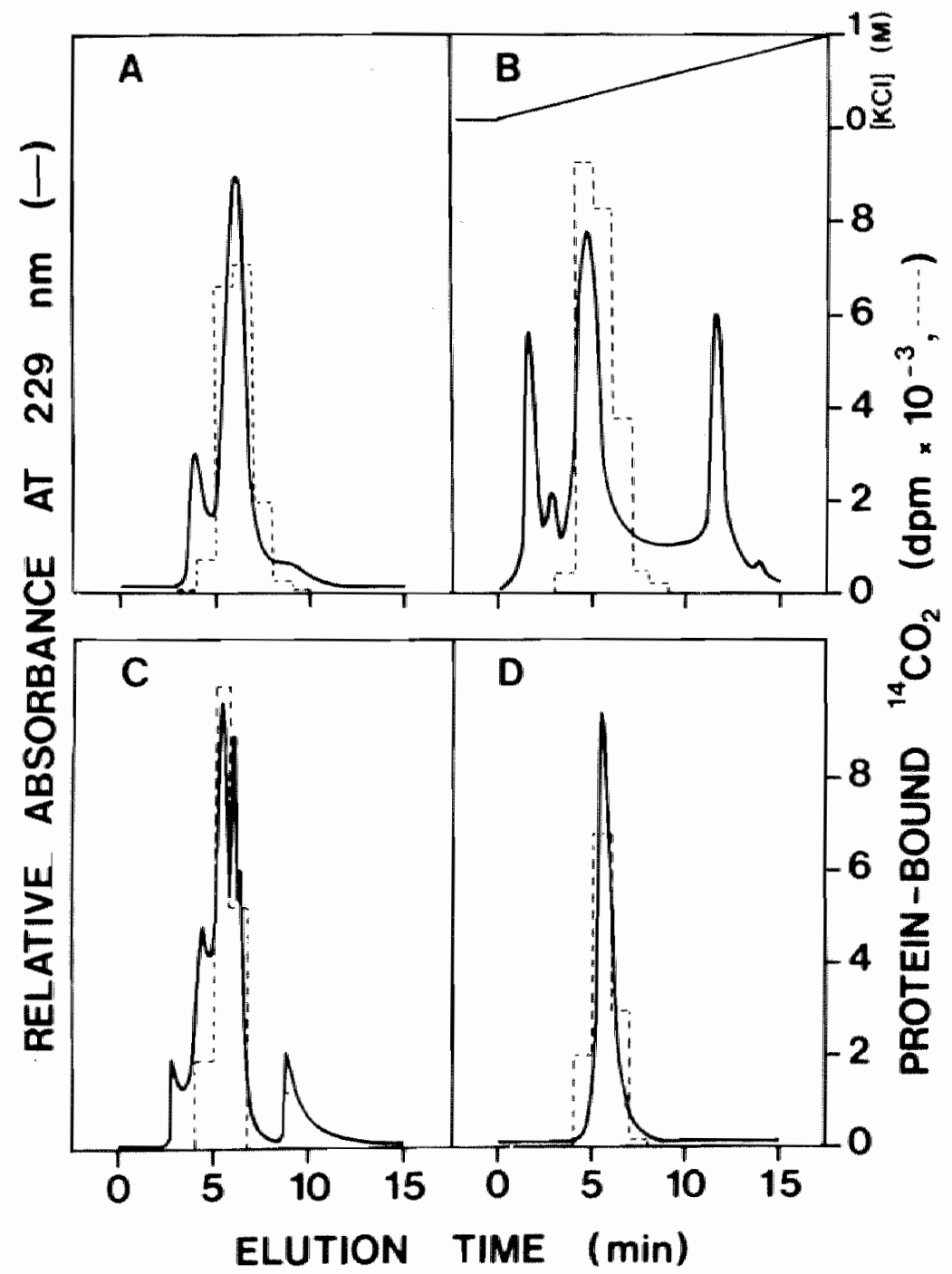

see page 74 
Pig. 2 .

HELC anxlyais of the decarboxylated 4-carboxyglutamic acid-containing protein from sperm

A: Crude decarboxylated aperm Gla-protein (d-S.G.P., $0.5 \mathrm{mg}$ ) was added to normat cow tiver carbqxylase and incubated in the presence of vitamin $\mathbb{K}$ hydroquinone and $\mathrm{NaH}^{1} \mathrm{CO}_{3}$ under standand conditions. Aftem $1 \mathrm{~h} 1 \mathrm{ml}$ of twichloroacetic acid $(5 \% \mathrm{w} / v)$ was added and after centmifugation the aupermatant was neutralized whith $1 \mathrm{MNaOH}$. Sodium dodecyl aulphate was added to a final concentration of $1 \%(\mathrm{w} / \mathrm{w})$. A acample of $0.05 \mathrm{ml}$ of this preparation was applited to a TSK-3000 SW colum in $0.1 \mathrm{M} \mathrm{NaCl}, 20 \mathrm{~mm}$ TMis-HCL, pH 7.5 and $0.1 \%(\mathrm{w} / \mathrm{v})$ sodium dodecyl sulphate. The flow rate wh $1 \mathrm{ml} / \mathrm{min}$. Practions of $1 \mathrm{ml}$ were collected and counted. The data in this difgrom are comected for the various dilutions and represent the total ${ }^{1 \mathrm{CO}_{2}}$ incorporation in $0.5 \mathrm{mg}$ d-S.G.P.

B: Crude d-S.t.P. (20 mg) was applied to a mono-Q anion exchange colum co desomibed in Materials and Methode. Fractions of $1 \mathrm{ml}$ were colleated and aliquots thereof $(0.05 \mathrm{~mL})$ were tested for the presence of d-S.G.P. in the bovine iver carboxylase asay.

C: The proteins eluting between 4 and 6 min were concentrated and applied to a TSK-3000 aolum in buffer $A$. The peaks were collected and tested for the presence of d-S.G.P. as described above.

$D$ : The protein peak eluting between 5 and 6 min was collected, concentrated and rechromatographed in buffer $A$ on the same column.

(d-S.G.P.) could be used as an exogenous substrate for the in vitro carboxylating enzyme system from normal bowine liver. Human liver carboxylase could not be used because of its high level of endogenous substrate (8). After the reaction mixtures had been incubated for 1 h at $25^{\circ} \mathrm{C}$ they were supplemented with trichloroacetic acid. The carboxylated d-S.G.P. was recovered in the supernatant and gel filtration chromatography (HPLC) in sodfum dodecyl sulphate showed the label to be exclusively present in a proteln peak with a molecular mass of about 34000 (fig. 2A).

since the Gla-determination is a technique too laborlous for the screening of sertes of column fractions, we decided to decarboxylate the sperm Gla-proteln in an early stage of 1 ts purification and to use the carboxylase assay for the detection of d-S.G.P. in the varlous fractions. The puriftcation of d-S.G.P. was accomplished by high performance liquid chromatography using lon-exchange and size-exclusion column (fig * $2 B$ and c). This procedure resulted in a preparation which migrated as a single peak during gel-filtration chromatography in the absence and presence of sodium dodecyl sulphate $(1 \%, w / v, f i g .2 D)$. The recovery of $d-S . G . P$. from $20 \mathrm{ml}$ of semen $1 \mathrm{~s}$ shown in table I. SDS polyacrylamide gel electrophoresis 
Table I

Purification of the decarboxylated 4-carboxyglutanic acid-containing protein from sperm

\begin{tabular}{lcccc}
\hline Step & proteln $(\mathrm{mg})$ & recovery (\%) of & purffication \\
\cline { 5 - 5 } & & $\mathrm{Gla}$ & substrate & (-fold) \\
\hline 1. Ejaculate $(20 \mathrm{ml})$ & 3600 & 100 & - & 1 \\
2. Spermatozoa & 640 & 72 & - & 4 \\
3. EDTA-extract & 46 & 45 & - & 35 \\
4. QAE-eluate & 20 & 40 & - & 72 \\
5. Decarboxylated & 20 & - & 100 & 72 \\
6. Mono Q & 3 & - & 135 & 648 \\
7. TSK-3000 SW & 0.6 & - & 61 & 1464 \\
8. TSK-3000 SW & & - & 56 & 2016 \\
rechromatography & 0.4 & & &
\end{tabular}

Since the thermal decarboxylation of the sperm Gla-protein routinely occurred after step 4, only the recovery of protein-bound Gla-residues was measured during the purification steps $1-4$. The purification factor (72fold) is based on the assumption that only one Gla-containing protein is present in the starting material. In step 5 the preparation was decarboxylated and could serve as a substrate for hepatic carboxylase.

The latter assay was used to measure the recovery of decarboxylated sperm Gla-protein.

of the purified material was performed in the absence and presence of 20 m dithiothreitol (EIg. 3). Under non-reducing conditions a single band was obtained, with an apparent molecular mass of 28000 . Under reducing conditions a low molecular weight peptide chain was dissociated from the heavy chain. From the fact that this dissoctation apparently does not cause a substantial decrease of the molecular mass of the heavy chatin, we conclude that the light chain may be smaller than indicated by its posttion in the gel. From these experiments we concluded that d-S.G.P. 1.s a two-chaln molecule with an estlmated molecular mass of approximately 30000.

The aninoacid composition of purified d-S.G.P. was determined after actd hydrolysis and is given in table II. Based on the assumption that only one methionine residue is present per molecule d-S.G.P., a molecular mass 


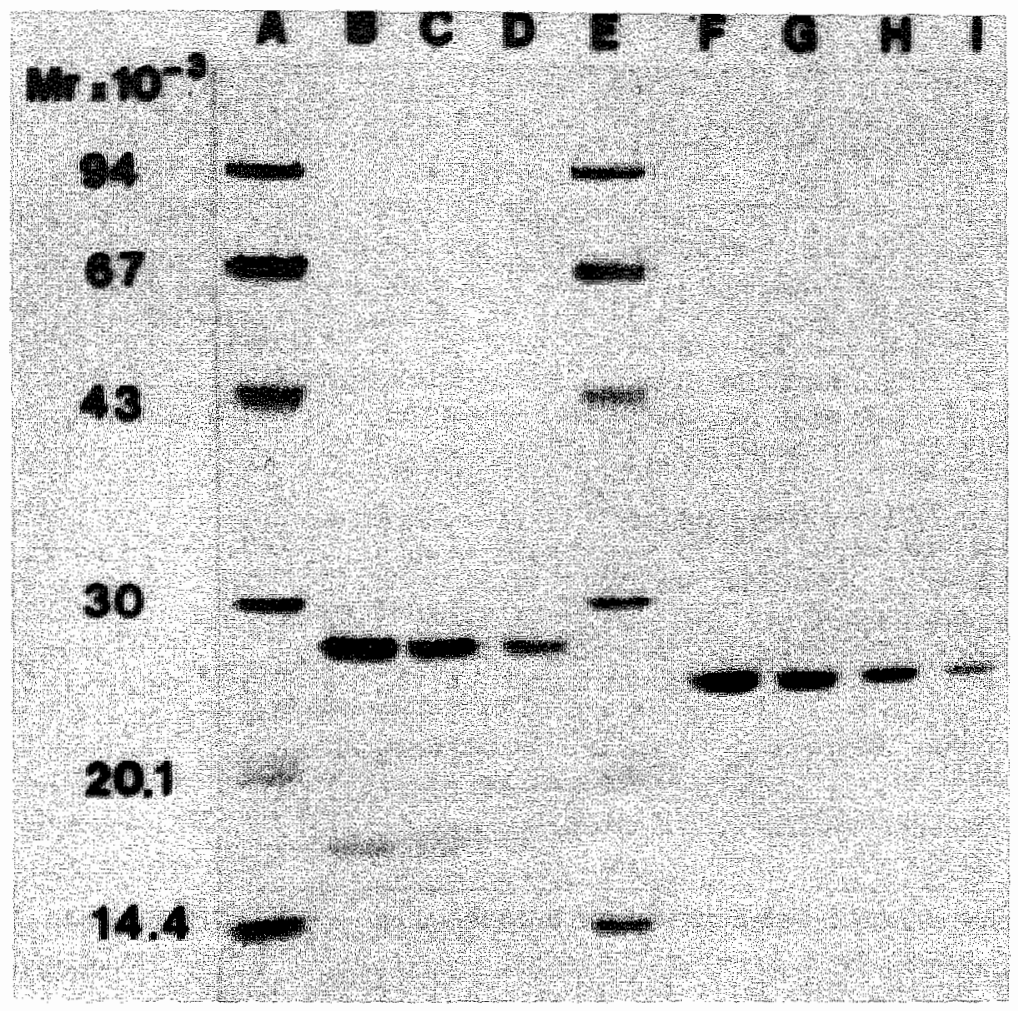

Fig. 3 .

SDS polyacrytamide gel analysis of the decarboxylated 4-carboxyglutamic acid-aontaining protein from sperm

Lanes $A$ and $E$ : marker proteins, reduced; Lanes $B, C$, and $D$ : decarboxylated operm Gla-protein, reduced $(20,15$ and $10 \mu \mathrm{g}$, reapectively); lanes $F, G, H$, and I: decarboxylated sperm Gla-protein, non-reduced $(25,20,15$ and $10 \mu g$, respectively).

of 28000 was calculated from the given aninoacid composition, which is in good agreement with our estimate from the HPLC gel filtration and polyacrylanide gel electrophoresis experiments. After the purification procedure for d-S.G.P. had been established we have also tried to purify non-decarboxylated Sperm Gla protein and to determine its Gla-content. Although the presence of Ga could be clearly established in the purified protein, for unknown reasons tis Gla-content varied from batch to batch, so that it was lmpossible for us to make a good estimate of the amount of Gla-residues per molecule of native proteln. 
Table II

Aninoacid composition of the decarboxylated 4-carboxyglutanic acidcontaining protein from sperm

\begin{tabular}{|c|c|c|}
\hline Amolnoacid residue & $\begin{array}{l}\text { Concentration in } \\
\text { hydrolysate }\left(\mu^{M}\right)\end{array}$ & $\begin{array}{l}\text { Number of residues } \\
\text { per proteln molecule }\end{array}$ \\
\hline Asx & 444 & 22.2 \\
\hline Thr & 261 & 13.1 \\
\hline Ser & 359 & 18.0 \\
\hline G1x & 777 & 38.9 \\
\hline Pro & 156 & 7.8 \\
\hline Gly & 283 & 14.2 \\
\hline Ala & 137 & 6.9 \\
\hline $\mathrm{Val}$ & 196 & 9.8 \\
\hline Cys & 432 & 21.6 \\
\hline Met & 20 & 1.0 \\
\hline Ile & 183 & 9.8 \\
\hline Leu & 216 & 10.8 \\
\hline Tyr & 105 & 5.3 \\
\hline Phe & 64 & 3.2 \\
\hline Lys & 306 & 15.3 \\
\hline His & 162 & 8.1 \\
\hline Arg & 121 & 6.1 \\
\hline $\operatorname{Trp}$ & $n \cdot d$. & $\mathrm{n} \cdot \mathrm{d}$. \\
\hline
\end{tabular}

The aminoacid composttion of the purified proteln was determined after acid hydrolysis. The number of residues per protein molecule was calculated on base of the assumption that one residue of Met is present per molecule. The data are not corrected for eventual hydrolysis losses. Trp was not determined because it is destroyed during acid hydrolysis.

\section{DISCUSSION}

The presence of carboxylase has been demonstrated in the test1s of rat $(2,10)$, steer (1), goat, ram and stallion (own unpublished results) thus suggesting that testicular carboxylation systems are indeed very common to 
mamalian species, including man. Though there was no experimental proof, 1. seemed plauglble that the endogenous substrate of testicular carboxylase might be a constituent of spermatozoa. Indeed Gla was detected in the sperm cell wash and after thermal decarboxylation the preparation contained a proteln that could serve as a substrate for bovine hepatic and testicular carboxylase. The isolation procedure resulted in the purification of a hitherto unknown proteln, the nascent form of which was designated as sperm Gla-proteln. Inttial characterization of its decarboxylated form (d-S.G.P.) was accomplished by determining its molecular weight and its aminoacid composition (table II). Striking is the very high content of Glx. It is likely, therefore, that the native protein contalns a high amount of Glu and Gla residues and that it thus bears a considerable negative charge. Possibly this negative charge destabilizes the Gla-residues to some extent so that they are partially lost during various steps of purification of the sperm Gla-proteln Thls would explain the batch to batch variation in the Gla-content of purifled sperm Gla-protein. Further research concerning the function of the spera Gla-protein is in progress in our laboratory.

\section{Acknowledgements}

The authors wish to thank Drs. H. Fritz and H.C. Hemker for their stimulating discussions and Mrs Molenaar-van de Voort for typing this manuseript. This research was supported by grant MD 82145 from the Trombosestichting Nederland and by grant-1n-ald Mn 598/L-5 from the Deutsche Forschungsgemeinschaft.

\section{REFERENCES}

1. Vermeer, $C_{.}$, Hendrix, H. and Daenen, M. FEBS Lett. 148: 317-320, 1982

2. Roncaglion, M.C., Soute, B.A.M., de Boer-van den Berg, M.A.G. and Vermeer, C. Blochem. Blophys. Res. Commun. $114: 991-997,1983$

3. Vermeer, C. Mol. Cell. Btochem. 61: 17-35, 1984

4. De Metz, M., Soute, B.A.M., Hemker, H.C. and Vermeer, C. Biochem. J. 209: $719-724,1983$

5. Poser, J.W. and Price, P.A. J. Biol. Chert. 254: 431-436, 1979

6. Kuwada, M. \& Katayama, K. Ana 1. Biachem. 131: 173-179, 1983

7. Laemili, R.J. Nature 227: $680-685,1970$

8. Lowry, O.H.., Rosebrough, N.J., Farr, A.L. and Randall, R.J. J. Blol. Chem. 137: 265-275, 1951

9. Soute, B.A.M., de Metz, M. and Verqeer, C. FEBS Lett. 146: 365-368, 1982

10. Buchtal, S.D. \& Be11, R.G. Blochemistry 22: 1077-1082, 1983 


\section{ISOENZYMES OF VITAMIN K-DEPENDENT CARBOXYLASE}

M.M.W. Ulrich, B.A.M. Soute, M.A.G. de Boer-wan den Berg and C. Vermeer

\section{SUMMARY}

Vitamin K-dependent carboxylase was prepared from bovine liver, kldney, lung and testis and it was checked that these enzyme systems obeyed the laws of normal enzyme kinetics. Four carboxylatable substrates were obtained from different sources and the apparent Michaelis constants of the various carboxylases for these four substrates were measured. From the results thus obtalned, we conclude that carboxylase is a group-name for a number of isoenzymes which are present in hepatic as well as in varlous non-hepatic tissues. 


\section{INTRODUCTION}

About ten years ago, vitamin K-dependent carboxylase was discovered in the liver, where it medates in the post-translational carboxylation of a number of proteins involved in blood coagulation $(1-3)$. Only recently, simlar enzyme systems were detected in non-hepatic tissues such as kidney, spleen, lung, testis, arterlal vessel wall and bone $(4,5)$. Since it is a common characteristic of all these enzyme systems that they use witamin $k$ as coenzyme, it is to be expected that all vitamin $K$ antagonists (e.g. warfarin, dicoumaro1) wi1 Inhibit carboxylase more or less to the same extent. This hypothesis is supported by the abservation of Roncaglioni et al. (6) that under mild oral ant coagulant treatment the enzyme systems in liver, lung, spleen and testis are 11 affected to some degree.

The question remains, however, whether the carboxylases from alfferent tissues are indistinguishable from each other. Contrarily, they also might form a famlly of isoenzymes. Since the various carboxylases are involved in the carboxylation of different substrates, it seemed plaustble that if differences would exist, they might be found at the substrate-binding site rather than at the vitamin-K-binding site. We therefore tried to answer this question by preparing carboxylase from four different types of bovine tissue and by measuring the kinetic constants of substrates from different origin in these systems. The results of our investigation are presented in this communteation.

\section{MATERIALS AND METHODS}

\section{Chemicals .}

Vitamin $\mathrm{K}_{1}$ (konakion ${ }^{\mathrm{R}}$ ) was obtalned from Hoffmann-La Roche (Basel, Switzerland) and chemically reduced to the hydroqulnone form (7). Warfarin, dithlothreitol, CHAPS (3-([3-cholamidopropy1]dimethylamonio $)-1-p r o p a n e s u l-$ fonate) and subtilisin were from Sigma (Saint Louls, U.S.A.), and the pentapeptide Phe-Leu-Glu-G1u-Leu ( F L E E L) from Vega (Tucson, U.S.A.). $\mathrm{NaH}^{14} \mathrm{CO}_{3}(40-60 \mathrm{Cl} / \mathrm{mol})$ was purchased from Amersham (U.K.) and Atomlight from New England Nuclear (Dreielch, F.R.G.). QAE-Sephadex and Sephadex G-25 were from Pharmacla (Uppsala, Sweden). All other chemlcals were from Merck (Darmstadt, $\cdot R \cdot G \cdot$ ). 


\section{Preparation of carboxylase.}

The various organs were obtained from normal cows whith half an hour after slaughtering and they were quickly cooled with ice-cold buffer $A(0.1$ M NaCl, $0.05 \mathrm{M}$ Tris-HCl, pH 7.4, $0.005 \mathrm{META}$ and $30 \%(\mathrm{v} / \mathrm{w})$ ethylene glycol). Crude microsomes were prepared from about $200 \mathrm{~g}$ of tissue as described earlier ( 7 ) and washed three thes by resuspension in $600 \mathrm{ml}$ of buffer $\mathrm{A}$, followed by centrifugation for $1 \mathrm{~h}$ at $105000 \mathrm{~g}$. Subsequently the microsomes were washed twice with $1 \mathrm{M} \mathrm{KCl}$ in buffer $\mathrm{A}$ and after the last centrifugation step they were solubilized in $1 \%(w / v)$ CHAPS in buffer $A$, to a final concentration of $40 \mathrm{mg}$ of protein per ml. The preparations were stored at $-80^{\circ} \mathrm{C}$ until use.

\section{Carboxylase assay.}

Unless stated otherwise, the incubation mixtures $(0.25$ mll) contalned: 2.5 mg of microsomal protein, $0.25 \%$ (w/v) CHAPS, $0.1 \mathrm{mM}$ vitamin k hydroquinone, $5 \mathrm{mM}$ dithiothreitol, $12 \%(\mathrm{v} / \mathrm{v})$ ethylene glycol, $1.5 \mathrm{M}\left(\mathrm{NH}_{4}\right)_{2} \mathrm{SO}_{4}, 0.005 \mathrm{mCl}$ $\mathrm{NaH}^{14} \mathrm{CO}_{3}$ and substrate as indicated. The reaction ixtures were incubated at $25^{\circ} \mathrm{C}$ and at the indicated time points the reaction was stopped by adding $2 \mathrm{ml}$ of $5 \%(\mathrm{w} / \mathrm{v})$ trichloroacetic acid. Traces of non-bound label. were removed by gentle boiling for 1 min before $10 \mathrm{mll}$ of Atomlight were added. The samples were counted in a Packard Tricarb Scintiliation counter.

\section{Determination of kinetic constants.}

Reaction mixtures containing varying substrate concentrations were incubated for $0,5,10,15,20,25$ and $30 \mathrm{~min}$. During this period the reaction rates were 1 inear in all experiments described in this paper. Blanc values (without vitanin $K$ hydroquinone) and the data obtafned without substrate were subtracted from the data obtalned in the presence of substrate. From the Lineweaver-Burk plot, constructed with these data, the apparent Michaelis constant $\left(K_{m}\right)$ and maximal reactlon rate ( $\left.W_{\text {max }}\right)$ were calculated.

\section{Preparation of substrates.}

osteocalcin was prepared from bovine bone (8) and partly purifled by batchwise adsorption to QAE-Sephadex in $0.15 \mathrm{M} \mathrm{NaCl}, 20 \mathrm{mM}$ Tris-HCl, pH 7.4 followed by a stepwise elution with $1 \mathrm{M} \mathrm{NaCl}$ before desalting, thermal decarboxylation and purffication by preparative high performance llquld chromatography (8). Descarboxyprothrombin fragment 13-29 was prepared by the proteolytic cleavage of purified bovine descarboxyprothrombin with 
subtlisin and purified with the ald of ion exchange and size exclusion chromatography (9). The GLa-containing protein from human sperm, the characterization of which wiL be reported elsewhere (B.A.M. Soute et a1., FEBS Lett. 190: 137-141, 1985), was prepared by homogenizing spermatozoa from $400 \mathrm{~mL}$ of semen in a buffer containing $1 \mathrm{H} \mathrm{KCl}, 20 \mathrm{mM}$ EDTA and 20 mM Trts-HCL, pH 7.4. The menbrane remnants were spun down (10 min, $1500 \mathrm{~g}$ ), and the supernatant was deluted 10-fold, adsorbed batchwise to 50 ml of QAE-Sephadex slurry and eluted stepwise with 1 M NaCl. The eluate was desalted on a Sephadex $G-25$ column $(85 \times 60 \mathrm{~cm})$ in water and was supplemented wh 0.1 HCl to a final pH of 2.0 and lyophylized. The preparation was than thermally decarboxylated $\left(24 \mathrm{~h}, 100^{\circ} \mathrm{C}\right.$ in vacuo $)$ and could serve as a substrate for carboxylase. The decarboxylated sperm Gla-protein (d-S.G.R.) was than dissolved in a $0.02 \mathrm{M}$ Tris-HCL buffer (pH 8.5) containing $0.1 \mathrm{M}$ KCL and purlfied further by high-performance liquid chromatography. The First purffication step was on a mono-Q anion exchange colurn (Pharmacia, $50 \times 5 \mathrm{~mm}$ ) and d-S.G.P. Was eluted with a linear gradient from 0.1 to $1 \mathrm{M} \mathrm{KCl}$ at a flow rate of $60 \mathrm{ml} / \mathrm{h}$. Fractions of $0.5 \mathrm{ml}$ were collected and the presence of d-S.G.P. was assayed by its ability to serve as a substrate for hepatic carboxylase. The amount of ${ }^{14} \mathrm{CO}_{2}$ incorporated into the exogenous: substrate was taken as a measure for the amount of d-S.G.P. In the various. fractions. The peak fractions were pooled, concentrated and subjected to a final purfication step on a TSK-3000 SW size excluston column (Beckman, $300 \times 7.5 \mathrm{manil})$ in $0.1 \mathrm{M} \mathrm{KCl}, 0.02 \mathrm{M}$ Tris-HC1, pH 7.4 .

proteln concentrations were deterialned according to Lowry et a1. (10)

RESULTS

Washed, solubilized microsomes were prepared from bovine liver, kidney, lung and testls and used as a source of carboxylase. The reliability of the enzyme systems was checked in a set of experiments in which the kinetic constants were measured at varying concentrations of mlcrosomes. The substrate chosen for these experiments was the pentapeptide F L E E L; all other reaction conditions were carefully kept constant. The results are presented in the form of Lineweaver-Burk plots (fig. 1). It is clear that the diagrams are linear and that the apparent Michaelis constants $\left(K_{m}\right)$ are 


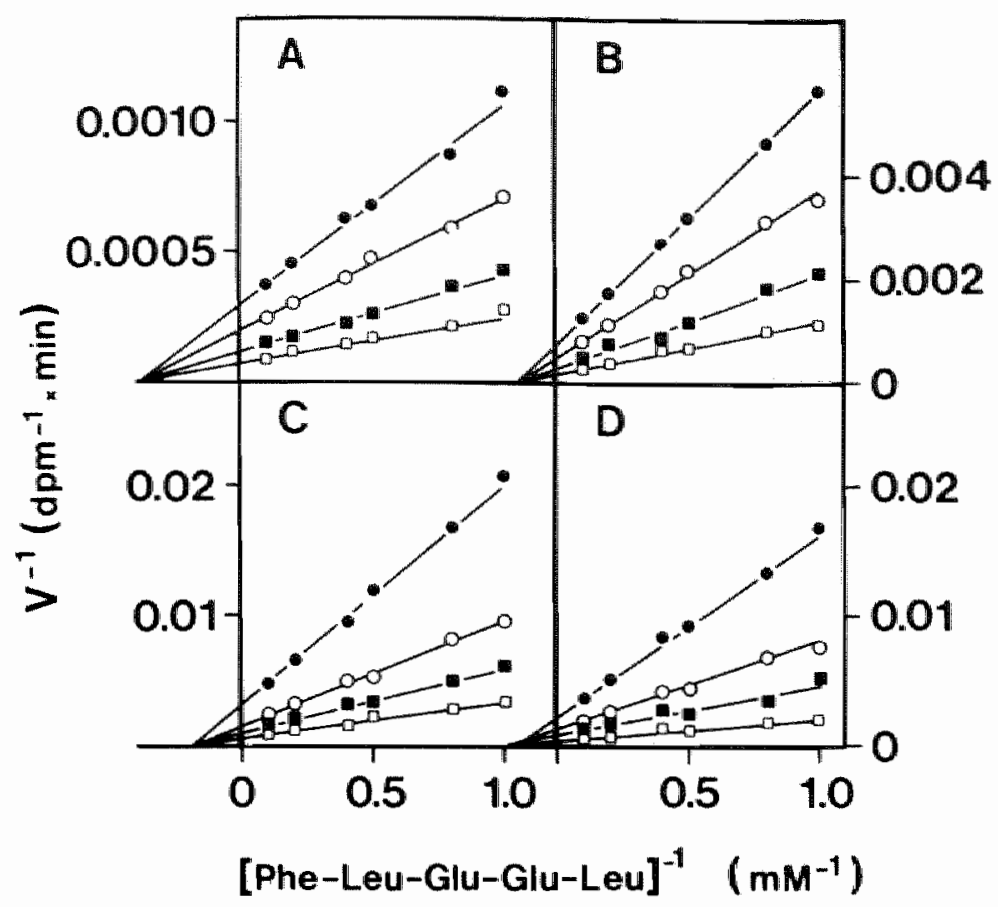

Eig. 1 .

Lineweaver-Burk plots at different enzyme concentrations.

Carboxylase was prepared from liver (A), kidney (B), Lung (C) and testia (D) and the initiat carboxytation rate of $F$ L $E L$ was measured at microsomal protein concentrations of $4,6,10$ and $16 \mathrm{mg} / \mathrm{mt}$. At each protein concentration, the concentmation of $F E E L$ was $10,5,2.5,2,1.25$ and 1 $m$. The initial carboxylation mates were calculated from time-courses laee Methods), which were made in tmiplicate, and blane values (minus vitamin $K$ and minus exogenous substratel were subtracted. The carboxylation rates are expressed as the amount of labet (dpm) incarporated into $F L E$ L per minute incubation time. Explanation of aymbols: - 4 , mg; $0-0,6$ mg; - $10 \mathrm{mg}$ and $\square-\square, 16 \mathrm{mg}$ of mierosomal proteine per ml inaubation mirature.

independent of the enzyme concentration. The maximal reaction rates ( $V_{\text {max }}$ ) were calculated from the intersections with the ordinates and they are shown in fig. 2 . Obwlously there is a linear relationship between the $V_{\max }$ and the erzyme concentration. We conclude that rellable measurments could be made within a rather wide range of enzyme concentrations and we have arbitrarily chosen to perform our experiments using 2.5 mg of microsomal protein per reaction mixture $(0.25 \mathrm{ml})$.

After having defined our enzyme systems, we prepared and purlfied the following carboxylatable substrates: bovine descarboxyprothrombin fragment 


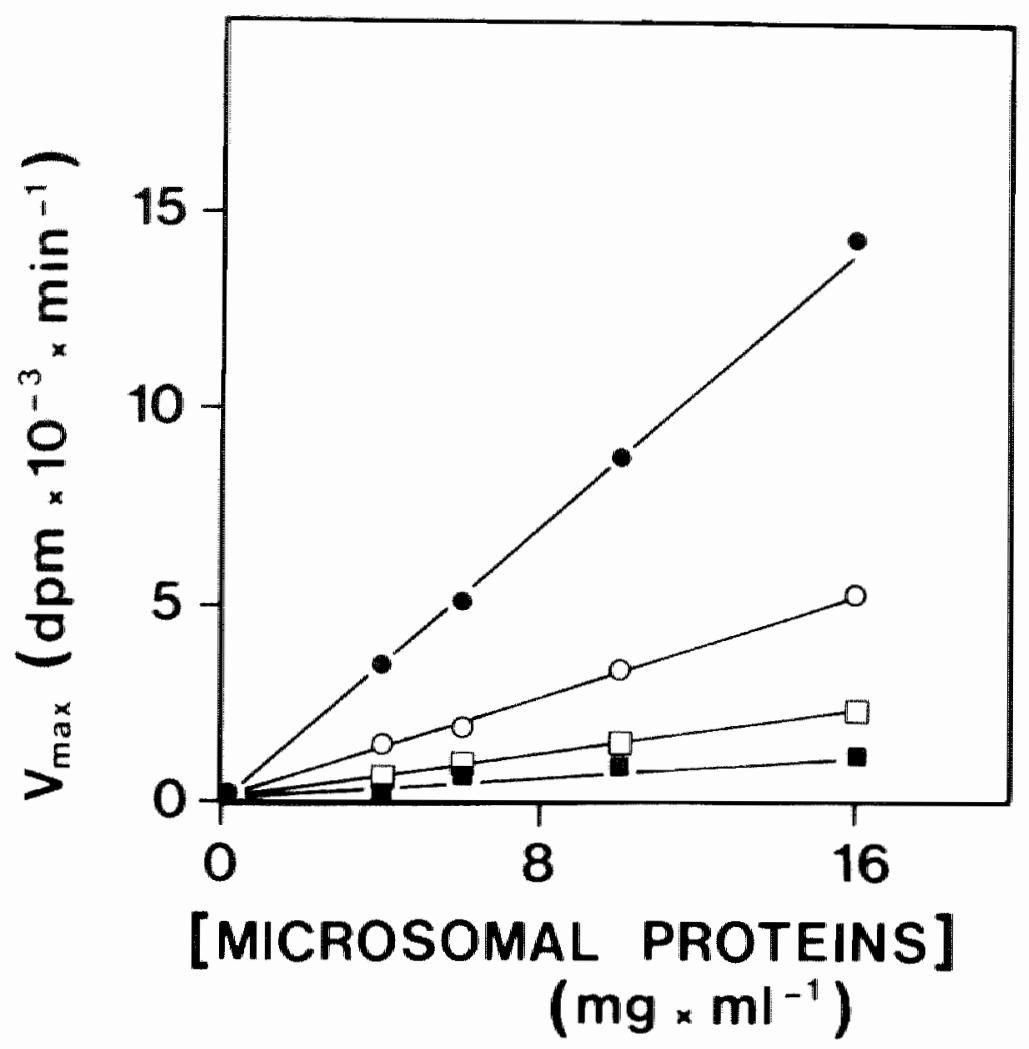

Fig. 2.

Vrax at different enayme concentrations.

The maximat reaction rates $(V$ ) were calculated from the intersections of the orinates in figure 1 and they are plotted against the concentination of microsomal proteins. Explanation of symbols: $\rightarrow$, Liver; o-o, kidney; -

13-29, decarboxylated osteocalcin (from bovine bone) and decarboxylated spern Glamprotein (from human sperm). The apparent $k_{m}$ walues for these aubstrates and for the pentapeptide F L E E L were measured in the various enzyme systems and the results of these experiments are sumarized in table I. "the carboxylase preparations may now be compared by calculating the ratio of the apparent $K_{m}$ values for two substrates in the various systems. When we take the data abtained with descarboxyprothrombin fragment 13-29 and decarboxylated sperm Gla-protein, for instance, this ratio is 0.014 in 
lung, 0.035 in liver and even 2.3 in testus carboxylase. It has to be concluded, therefore, that differences exist between vartous carboxylases with respect to their substrate spectficity.

Table I

Apparent Michaelis constants in varilous systems.

\begin{tabular}{lcccc}
\hline Apparent $K_{m}(\mathrm{mM})$ & $\begin{array}{c}\text { in carboxylase from } \\
\text { Liver }\end{array}$ & Kidney & Lung & Testis \\
\hline F L E E L & 2.6 & 7.1 & 5.3 & 6.5 \\
d-osteocalcin & 0.028 & 0.027 & 0.008 & 0.011 \\
fragment-Su & 0.003 & 0.006 & 0.003 & 0.028 \\
d-S.G.P. & 0.085 & 0.158 & 0.204 & 0.012
\end{tabular}

The incubations were performed in standard reaction mixtures $(0.25 \mathrm{ml})$ containing $2.5 \mathrm{mg}$ of microsomal proteins. D-osteocalcin stands for decarboxylated osteocalcin and d-S.G.P. for decarboxylated sperm Gla-proteitn.

\section{DISCUSSION}

Although hepatic carboxylase has been discovered more than ten years ago, its purification from the crude microsomal fraction has not yet been completed $(11,12)$. Non-hepatic carboxylases have even not been purlfied beyond the step of solubilization of the microsomes. The lack of a purlfied enzyme has been a serious drawback for investigations concerning the mechanism of the carboxylation reaction. On the other hand, Lf the appropriate controls are made, some information can also be abtained from the non-purifled systems. In this way we have compared the substrate specifictites of carboxylases derived from different types of tissue. Before we could start our investigations, we had to make sure that the kinetics of these systems were reliable, which means that: a) the $k_{m}$ for a given substrate is independent of the enzyme concentration and b) a linear relationship exists between the $V_{\max }$ and the enzyme concentration. It 
turaed out that -provided that the microsomes were thoroughly washed- these conditions were met whin a rather wide range of enzyme concentrations and we have arbitrarily chosen to perform our experinents using $2.5 \mathrm{mg}$ of microsomal protelns per reaction mixture $(0.25 \mathrm{ml})$. In this way we have reasured the $K_{\text {m }}$ values of carboxylase from various types of tissue for four different carboxylatable substrates. As is shown in table I, all substrates wre carboxylated in each system, but the $K_{\text {m }}$ values for a given substrate differed from one system to another. Descarboxyprothrombin fragment 13-29, For instance, is a rather good substrate (low $\mathrm{K}_{\mathrm{m}}$ ) in liver and in $1 \mathrm{ung}$ carboxylase, but it is worse in testis carboxylase. Decarboxylated sperm Glaprotein, on the other hand, has a low $\mathrm{k}_{\mathrm{m}}$ in the testicular system, but a 7-15 fold higher $k_{m}$ in carboxylase from 11ver, lung and kidney. Therefore dit seems that carboxylases from different types of tissue may differ from each other with respect to their substrate selection and thus may be regarded as isoenzymes. The results shown in table I also show that some primary or secondary aminoacid structure is required for an efficient enzyme/substrate interaction since it is evident, that the $\mathrm{k}_{\mathrm{m}}$ for the smallest substrate $F \mathbb{L} E \mathbb{L}$ is high in all four enzyme systems.

It has been shown, that vitamin $K$ antagonists inhibit hepatic as well as non-hepatic carboxylases $(5,6)$, possibly because the vitamin $k$-binding sttes of all enzyme systems are closely similar. Now it turns out that differences may exist at the substrate-binding sites, it would -at least in principle- be possible to construct more specific inhibitors, which interfere whth one type of carboxylase much stronger than with the others. Obviously these Inhibttors should be non-carboxylatable substrate analogs auch as those synthestzed by Gaudry et al. (1.3) and by Rich et al. (14). Although $t$ was demonstrated that these substrate analogs are potent inhibitors of hepatic carboxylase, they have unfortunately not been tested in non-hepatic enzyme systems. Obviously the development of these and other substrate-analogs will help us to get more insight into the mechanism of the substrate selection by witanin $K$-dependent carboxylase.

\section{Acknowledgements}

The authors wish to thank dr. H.C. Hemker for his stimulating discussions and mrs. M. Molenaar-van de Voort for typing this manuscript. 
Our research is supported by grant $\mathrm{MD} 82145$ from the Trombosestichting Nederland, grant 684.463 from the Nier Stichting Nederland and grant: 13-50-52 from the Division for Health Research, TNO.

\section{REFERENCES}

1. Esmon, C.T., Sadowski, J.A. and Suttie, J.W. J. Biol. Chem. 250: $4644-4748,1975$

2. Mack, D.O., Suen, E.T., Girardot, J.M., Miller, J.A., Delaney, R. and Johnson, B.C. J. Biol. Chem. 251: 3269-3276, 1976

3. Vermeer, C., de Metz, M., Soute, B.A.M. and Henker, H.C. in Protides of Biological Fluids, 28th Colloquiun (Peeters, H., ed.) Vol. 28, pp. 249-252, 1980 Pergamon Press, Oxford.

4. Buchta1, S.D. and Be11, R.G. Biochemistry 22: 1077-1082, 1983

5. Vermeer, C., Hendrix, H. and Daemen, M. FEBS Lett. 148: 317-320, 1982

6. Roncaglionl, M.C., Soute, B.A.M., de Boer-van den Berg, M.A.G. and Vermeer, C. Biochem. Biophys. Res. Commun. 114:991-997, 1983

7. Vermeer, C., Soute, B.A.M., de Metz, M. and Hemker, H.C. Blochlin. Biophys. Actai 714: 361-365, 1982

8. Vermeer, C., Soute, B.A.M., Hendrix, H. and de Boer-van den Berg, M.A.G. FEBS Lett. 165: 16-20, 1984

9. Soute, B.A.M., Vermeer, C., de Metz, M., Hemker, H.C. and Li jnen, H.R. Biochim. Biophys. Acta 676: 202-207, 1981

10. Lowry, O.H., Rosebrough, N.J., Farr, A.L. and Randa11, R.J. J. Biol. Chem . 193: 265-275, 1951

11. De Metz, M., Vermeer, C., Soute, B.A.M., van Scharrenburg, G.J.M., Slotboon, A.J. and Hemker, H.C. FEBS Lett. 123, 215-218, 1981

12. Girardat, J.M. J. Blol. Chem. 257, 15008-15011, 1982

13. Gaudry, M., Bory, S., Dubols, J., Azerad, R. and Marquet, A. Biochem. Biophys. Res. Commun. 113: 454-461, 1983

14. Rich, D.H., Kawal, M., Goodman, H.L., Enge1ke, J. and Suttie, J.W. FEBS Lett. 152: $79-82,1983$ 



\title{
VITAMIN K-DEPENDENT CARBOXYLASE:
}

\section{THE CARBOXYLATION OF EXOGENOUS SUBSTRATES IN DIFFERENT SYSTEMS}

\author{
M.A.G. de Baer-van den Berg, M.M.W. Ulrich, H.C. Hemker, \\ B.A.M. Soute, C.Vermeer
}

\section{SUMMARY}

Two types of solid-phase carboxylase, SPC-II and SPC-X have been prepared from the livers of warfarin treated cows. Thelr enzymatic activities were compared with substrate-free carboxylase in mlcrosones from norma1 cows and substrate-bound carboxylase in microsomes from warfarin treated cows. A number of exogenous substrates for carboxylage have been purified and tested. We found that large substrates, such as descarboxyprothrombin, are only carboxylated by substrate-free carboxylase and not by the substrate-bound enzyme. No differences in apparent $\mathrm{Km}$ values between $S P C-I I$ and SPC-X were observed. 


\section{LNTRODUCNION}

Wtamin $K$-dependent carboxylase is a microsomal enzyme system involved In the postcransiational modification of proteins $(1,2)$. Initially, the sygrem was thought to be uniquely present in liver, but later on carboxylase was also detected in other tissues such as lung, spleen, kidney, testis and arterial wessel wall (3,4). Whether all these carboxylases are 1 dentical is still a matter of research. Contrarily they also might form a fanily of isoenzymes and it cannot even be excluded, that different isoenzymes are present in one type of tissue.

Hepatic carboxylase is used in most studies concerning the vitamin $k$-dependent reaction. The characteristics of the enzyme preparation may depend on the donor animal pretreatment and the enzyme preparation procedure. Crude microsomal extracts from normal animals contaln only a very small amount of endogenous substrate and therefore the preparation is called substrate-free carboxylase (5), whereas substrate-bound carboxylase is obtained form the livers of warfarin-treated animals $(5,6)$. The endogenous substrate mainly consists of precursors of the coagulation factors II (prothrombin) and $X(7)$. When the solubilized substrate-bound microsomes are extracted with Sepharose-linked antibodies against factor $X$ (7) or prothrombin (8), two types of Solld-phase carboxylase (SPC) are obtalned. They are designated as SPC-X and SPC-II, respectively.

We have prepared these four types of carboxylase from bovine liver and we have conpared their respective properties. The results of our investigations are presented in this paper.

\section{MATERIALS AND METHODS}

\section{Chemica1s.}

Vitamin $K_{1}$ (Konakion ${ }^{R}$ ) was obtained from Hoffmann-La Roche (Switzerland) and vitamin $K$ hydroquinone was prepared as described previously (9). The synthetic substrate Phe-Leu-Glu-Glu-Leu (E L E E L) was obtained from Vega-Biochemicals (U.S.A.), $\mathrm{NaH}^{14} \mathrm{CO}_{3}(40-60 \mathrm{Ci} / \mathrm{mol})$ from Amersham (U.K.) and Atomlight from New England Nuclear (F.R.G.). Warfarin, benzamidine, dithiothreitol (DTT), bovine albunin, Triton-X 100 and 3 -[ ( 3 cholamido- 
propyl)dimethylammonio -1-propane sulfonate (CHAPS) were purchased from Sigma (U.S.A.). CNBr-actiwated Sepharase, Sephadex G-25, G-100, G-200 and DEAE Sephadex were obtained from Pharmala (Sweden). The proteases subtilisin and chymotrypsin were obtained from Boehringer. All other chemicals were from Merck (F.R.G.).

Preparation of antibodies. Bovine prothrombin was prepared as described by Owen et al. (10) and antibodies agalnst the purified antigen were raised in goats. Anti-prothrombin antibodies were spectfically extracted from the immune serum with the aid of Sepharose-bound prothrombin and eluted with 3 $M$ KCNS. The purified antibodies gave single precipitatin lines agalngt normal reference plasma in an Ouchterlony diffusion test (11). After dialysis against $0.15 \mathrm{M} \mathrm{NaCl}, 20 \mathrm{mM}$ Tris-HCl pH 7.5, the anthodies were bound to CNBr-activated Sepharose (10-15 mg of protein per $g$ of dry Sepharose). Bowine factor $X$ was prepared as described by Fujikawa et al. (12) and Sepharose-bound anti-factor $X$ antibodies were prepared in a similar way as described for antiprothrombin. The Sepharose-bound antiprothrombin was able to extract prothrombin from normal bovine plasma without affecting the level of factor $X$ and vice versa.

Preparation of microsomal carboxylase. Cows were anticoagulated during one week by the oral administration of warfarin (10 $\mathrm{mg} / \mathrm{kg}$ body weight daily). Crude microsomes were prepared from the livers of normal and warfarin treated cows as described earlier (5). After three washing cycles the microsomes were suspended in buffer $\mathrm{A}(1 \mathrm{M} \mathrm{NaCl}, 0.05 \mathrm{M} \mathrm{Tris} / \mathrm{HCl} \mathrm{pH} 7.5,1$ mM EDTA, $20 \%$ ethyleneglycol) to a concentration of 50 mg proteln per mi and stored at $-80^{\circ} \mathrm{C}$.

Preparation of solid-phase carboxylase (SPC). Microsomes from warfarintreaced cows were suspended in buffer $A(50 \mathrm{mg}$ protein/ml) and solubilized by the addition of CHAPS to a final concentration of $1 \%(w / v)$. Non-solubilized material was spun down $(90 \mathrm{~min}$ at $100000 \mathrm{~g}$ ) and the supernatant was supplemented with an equal volume of distflled water and $1 \mathrm{mg}$ sodium azide per $100 \mathrm{ml}$. $40 \mathrm{ml}$ of this preparation was incubated with $10 \mathrm{ml}$ Sepharose-bound antibodies against either prothrombin or factor $x^{\prime}$; this suspension was rotated end over end at $4{ }^{\circ} \mathrm{C}$. A maximal amount of carboxylase activity was bound to the Sepharose after $24 \mathrm{~h}$ for SPC-X and after $3 \times 24 \mathrm{~h}$ for SPC-II. In the latter case the solubilized microsomes were refreshed after each period of $24 \mathrm{~h}$. After the complete incubation, 
the Sepharose-beads were washed with buffer B $6.1 \mathrm{M} \mathrm{NaCl}, 0.05 \mathrm{M}$ Tris-HCL pH 7.5, $1 \mathrm{mM}$ EDTA), suspended $1 \mathrm{n}$ an equal volume of buffer $B$ and stored untll use at $-80{ }^{\circ} \mathrm{C}$.

Measurement of carboxylase activity. The vitamin $\mathrm{K}$-dependent incorporation of ${ }^{14} \mathrm{CO}_{2}$ was measured by incubating $0.25 \mathrm{ml}$ reaction mixtures in buffer $\mathrm{B}$ contaluing $0.1 \mathrm{ml} \mathrm{SPC}\left(0.05 \mathrm{mg}\right.$ proteln) $0.01 \mathrm{mCl} \mathrm{NaH}^{14} \mathrm{CO}_{3}, 8 \mathrm{mM}$ DTT, $0.2 \mathrm{mM}$ vitamin $k$ hydroquinone and exogenous substrate as indicated. The tubes were sealed and incubated in a shaking water bath for 1 hour at $25^{\circ} \mathrm{C}$ unless indicated otherwise. The incubation was stopped by adding $0.25 \mathrm{ml}$ ice-cold buffer A followed by centrifugation at $2000 \mathrm{~g}$ for $10 \mathrm{~min}$ at $4 \mathrm{c}$. An aliquot $(0.25 \mathrm{ml})$ of the supernatant was transferred to a counting vial and non-bound ${ }^{14} \mathrm{CO}_{2}$ was removed by adding $2 \mathrm{~m} 1$ trichloroacetic acid (5\%) and bolling the solution for two minutes. The samples were supplemented with 10 ml Atonlight and counted in a Packard Tricarb scintillation counter. To measure the amount of endogenous substrate carboxylation, no exogenous substrate was added and after incubation the complete reaction mixture was transferred to a counting vial and treated further as described above. When microsomes from normal or warfarin-treated cows were used $(5$ mg proteln per $0.25 \mathrm{ml}) 0.4 \%$ CHAPS $(\mathrm{W} / \mathrm{v})$ and $\mathrm{I} \mathrm{M}\left(\mathrm{NH}_{4}\right)_{2} \mathrm{SO}_{4}$ were added to the reaction mixture as described for solid phase carboxylase. In all experiments, parallel incubations were performed in the absence of vitamin $k$ hydroquinone and DTT; these blank values were subtracted.

Preparation of substrates. Descarboxyfactor II and descarboxyfactor $X$ were prepared from the blood of warfarin-treated cows, according to the dethods of Stenflo and Ganrot (13) and Lindhout et al. (14), respectively. Fragment-Su, the subtilisin fragments 13-29, were prepared by digesting the descarboxyfactors with sepharose-bound subtilisin; the fragments were purifted by lon-exchange and stze exclusion chromatography (15). The chymotryptic fragments $1-41$ (16) were obtained by digestion of the descarboxyfactors with Sepharose-bound chymotrypsin and party purifted by lon-exchange chromatography. Decarboxylated bovine osteacalctin (49 and noacid residues) was prepared as described earlier (17).

Determination of apparent $\mathrm{Km}$ values. Solid phase carboxylase reaction mixtures containing varying substrate concentrations were incubated for 0 , 15, 30, 45 and $60 \mathrm{~min}$. During this period the reaction rates were linear in all experiments described in this paper. At least five different substrate 
concentrations were used in the range of $0.5-10 \mathrm{mM}$ for F L E E L, $1-100$ $\mu^{M}$ for the descarboxyfactors $I I$ and $X$ and for decarboxylated osteocalcin and 0.1 - $10 \mu \mathrm{M}$ for the subtilisin fragments of the descarboxyfactors. The amounts of incorporated ${ }^{14} \mathrm{CO}_{2}$ in the absence of added substrate were subtracted. The inverse of the initial reaction rates thus obtained was plotted against the inverse substrate concentration. From the resulting Lineweaver Burk plot the apparent Michaelis constant $\left(\mathrm{K}_{\mathrm{m}}\right)$ was calculated according to the method of Eisenthal and Cornish-Bowden (18).

other methods. Protein concentrations were determined according to Lowry et al. (19). The protein content of solid phase carboxylase was measured after its elution from the Sepharose beads with $6 \mathrm{M}$ urea in $2 \%$ sodlum dodecyl sulphate. Protein-bound Gla-residues were determined as described by Kuwada and Katayama (20).

\section{RESULTS}

SPC-II and SPC-X were prepared as described in Materials and Methods. The optimal reaction conditions for carboxylation were similar to those in the crude microsomal systems except for the fact that in the solid phase systems, detergents, even at low concentrations, acted strongly inhtbitory. Although the two SPC"s presumably contain different substrates no differences between the complexed carboxylases could be observed. In both types of enzyme the endogenous substrates were carboxylated preferentially during the first $15-20$ minutes and after this perfod exogenous substrates such as F $L E E L$ were carboxylated with a constant reaction rate for more than $2 \mathrm{~h}$. The lag-phase in carboxylation of exogenous substrates may be circumvented by preincubation of SPC in the presence of vitam $K$ hydroquinone and non-labeled $\mathrm{NaHCO}_{3}$ for $1 \mathrm{~h}$. In the experiments described below, pre-incubated SPC was used.

To compare the affintities of the Sepharose-bound enzymes, a number of carboxylatable substrates were prepared. Descarboxyfactors II and $x$ were Isolated from plasma of warfarin treated cows and purtfled. Since thermal decarboxylation $(21,22)$ of normal prothrombin and factor $X$ could not be reproducibly repeated we have used descarboxyfactors throughout our experiments. Smaller substrates were obtained by subtilisin cleavage of descar- 
Table I

Kinetic constants of various substrates for SPC II and SPC-X

$\mathrm{Km}(\mathrm{mM})$

Substitate

SPC II

SPC $X$

D - II

$\mathrm{n} \cdot \mathrm{m} \cdot$

$\mathrm{n} \cdot \mathrm{m} \cdot$

$\mathrm{D}-\mathrm{X}$

n. ㄸ.

n. $\cdot$ m.

D $-I$ I fr. Su

0.0014

0.0013

$\mathrm{D}-\mathrm{X}$ fr. Su

0.0013

0.0016

D-osteocalcin

0.036

0.045

E L E E L

3.1

2.7

The apparent $\mathrm{Km}$ values were calculated from the initial carboxylation rates at various concentrations of the substrate, as described in Materials and Methods. Abbreviations used: D-II, descarboxyfactor II; D-X, descarboxyfactor X. Fr. Su, subtilisin fragment; D-osteocalcin, decarboxylated osteocalcin; $n \cdot m$. not measurable.

boxyfactors which yields a carboxylatable peptide of 17 amino acid residues (fragment $\mathrm{Su}$ ). Furthermore osteocalcin was isolated from bovine bone and decarboxylated in vitro. In none of these preparations Gla could be detectied.

No differences between SPC II and SPC X were found (table I). Moreover the large substrates were not carboxylated at all. To exclude the possiblity that the descarboxyfactors were bound by free antibodies on the Sepharose the SPC's were pre-lacubated with either bowline prothrombin or factor $X$ before addition of the descarboxyfactors. This treatment had no effect on the anount of carboxylation measured.

Since both SPC's are substrate-bound enzyme systems, we have checked whether the endogenous substrates might hamper the carboxylation of large exogenous substrates. For that purpose we have compared the properties of substrate-free and substrate-bound carboxylase in detergent-solubilized microsomes from normal and warfarin treated cows, respectively. Except for 
Table II

Carboxylation of exogenous substrates by substrate-free icrosomes, substrate-bound microsomes and solid-phase carboxylases.

Substrate Conc. (mM) ${ }^{14} \mathrm{CO}_{2}$ incorporated (dpro/h)

\begin{tabular}{|c|c|c|c|}
\hline $\begin{array}{l}\text { substrate-free } \\
\text { microsomes }\end{array}$ & $\begin{array}{l}\text { substrate-bound } \\
\text { microsomes }\end{array}$ & SPC-II & $S P C-X$ \\
\hline
\end{tabular}

\begin{tabular}{llrrrr}
\hline none & & 820 & 16200 & 90 & 110 \\
D-II & 0.01 & 900 & 16080 & 90 & 105 \\
D-II & 0.1 & 4020 & 16150 & 110 & 140 \\
D-X & 0.01 & 880 & 16200 & 100 & 110 \\
D-X & 0.1 & 3870 & 16000 & 110 & 120 \\
D-II fr. Su & 0.01 & 25430 & 51380 & 4120 & 6970 \\
D-X fr. Su & 0.01 & 24340 & 48660 & 4530 & 6340 \\
D-II fr. C.T. 0.01 & 20060 & 38300 & 2260 & 2850 \\
D-X fr. C.T. 0.01 & 18680 & 27700 & 2120 & 2730 \\
D-osteocalcin & 0.01 & 14920 & 35020 & 3740 & 4750 \\
F L E E L & 0.01 & 830 & 16200 & 100 & 1.10 \\
F L E E L & $\mathbb{1 . 6}$ & 35800 & 88600 & 5880 & 10720
\end{tabular}

The carboxylation reaction was performed under standard conditions. The values are the means of triplicate measurements. fr. C. T. stands for chynotryptic fragment; for other abbreviations, see the text to Table $I$.

the substrates mentioned in table $I$ we have also used the carboxylatable chymotryptic cleavage product ( 41 residues) of the descarboxyfactors. The results of these experiments are shown in table II. It 1 s clear that the peptide substrates (up to 49 aninoacid residues) were good substrates in both systems, whereas the protelin substrates could only be carboxylated in substrate-free carboxylase. 


\section{DISCUSSION}

It has been shown earlier, that with the ald of Insolubilized antibodies agalnst blood coagulation factor $x, 65 \%$ of the substrate-bound carboxylase could be extracted from solublifzed microsomes (7). From the superatant no more complexes could be bound with insolubilized antifactor $X$, but still $21 \%$ with antiprothrombin. Together with the analyses of the extracted proteins (7), these experiments strongly indicate that no prothrombin precursors occur in SPC-X and wice versa. No indications were obtalned for any difference between the carboxylases present in the two solld phase systems, however.

On the other hand we did find a difference between substrate-free and substrate-bound carboxylase. Large substrates such as descarboxyprothrombin and descarboxyfactor $X$ were carboxylated, albeit poorly, in substrate-free carboxylase, whereas in the substrate-bound systems (in neither solubilized microsomes nor SPC) these protein substrates were not carboxylated. From our work with SPC-X we know, that even after completion of the carboxylation reaction the enzyme and its carboxylated endogenous substrate remain flrmly complexed, although the carboxylation of small peptides such as $F$ L E E L occurs uninhlbited. The experiments shown in this paper clearly indicate that in substrate-bound carboxylase, possibly because of sterical hindrance by the endogenous substrate, the carboxylation of exogenous substrates is hampered. Therefore substrate-free carboxylase (from the liver of normal, non-treated animals) is the enzyme system of cholce when the affinity of carboxylase for various substrates is investigated.

\section{Acknowledgement}

The authors wish to thank Mrs. M. Molenaar-v.d. Voort for typling this manuscript. Our research is supported by grant MD 82145 from the Trombosestichting Nederland.

\section{REFERENCES}

1. Suttie, J.W. GRC Crit. Rev. Biochem. 8: 191-223, 1980

2. Vermeer, C. Mol. Ce11. Blochem. 61: 17-35, 1984

3. Buchta1, S.D. and Bel1, R.G. Blochemistry 22: 1077-1082, 1983 
4. Vermeer, C., Hendrix, H. and Daemen, M. FEBS Lett. 148: 317-320, 1982

5. Vermeer, C., Soute, B.A.M., De Metz, M. and Hemker, H.C. Blochim. Biophys. Acta 714: $316-365,1982$

6. Suttie, J.W., Lehrman, S.R., Geweke, L.O., Hageman, J.M. and Rich, D.H. Biochem. Blophys. Res. Commun. 86: 500-507, 1979

7. De Metz, M., Vermeer, C., Soute, B.A.M., van Scharrenburg, G.J.M., Slotboon, A.J. and Hemker, H.C. FEBS Lett. 123, 215-218, 1981

8. Olson, R.E., Hall, A.L., Lee, F.C., Kappel, W.K., Meyer, R.G* and Bettger, W.J. in: Posttranslational covalent modifications of proteins (Johnson, B.C. ed.) pp. 295-319, 1983, Academic Press, New York

9. De Metz, M., Soute, B.A.M., Hemker, H.C. and Vermeer, C. Blochern. J. 209: $719-724,1983$

10. Owen, W.G., Esmon, C.r. and Jackson, C.M. J. Biol. Chem. 249: 594-605, 1974

11. Ouchterlony, 0. Progr. Allergy 6: 130-15.4, 1962

12. Fujlkawa, K., Legas, M.E. and Davie, E.W. Biochernistry 11: 4882-4891, 1972

13. Stenflo, J. and Ganrot, P.0. J. Biol. Chem. 247: 8161-8167, 1972

14. Lindhout, M.J., Kop-Klaassen, B.H.M., Kop, J.M.M. and Hemker, H.C. Biochim. Biophys. Acta 533: 302-317, 1978

15. Soute, B.A.M., Vermeer, C., de Metz, M., Henker, H.C. and Lijnen, H.R. Biochim. Biophys. Acta 676:101-107, 1981

16. Dode, C., Thiesce, A., Labie, D. and Elion, I. Blochem. Blophys. Res. Commun. 103: 461-468, 1981.

17. Vermeer, C., Soute, B.A.M., Hendrix, H. and De Boer-van dan Berg, M.A.G. FEBS Lett. 165: 16-19, 1984

18. Eisentha1, R. and Cornish-Bowden, A. Biochem . J. 139: 71.5-720, 1974

19. Lowry, O.H., Rosebrough, N.J., Farr, A.L." and Randall, R.J. J. Biol. Chem. 193: 265-275, 1951

20. Kuwada, M. and Katayama, K. Ana1. Biochem. 131: 173-179, 1983

21. Poser, J.W. and Price, P.A. J. Biol. Chem. 254: 431-436, 1979

22. Tuhy, P.M.,Bloom, J.W., and Mann, K.G. Blochemistry 18: 5842-5848, 1979 
DIRECT MEASUREMENT OF VITAMIN K-DEPENDENT ENZYMES IN VARIOUS ISOLATED AND CULTURED TUMOR AND NON-TUMOR CELLS

M.A.G. de Boer-van den Berg, M.P. Uitendaal and C. Vermeer

SUMMARY

A modification of the assay for vitamin K-dependent carboxylase $1 \mathrm{~s}$ described with which the enzyme could be detected in relatvely low anounts of cells ( $\mathrm{n}=10^{6}$ ). Using this assay, we could demonstrate vitamin K-dependent carboxylase activity in hepatacytes, renal tubular cells, asteoblasts, endothelial cells and macrophages, but not in lymphocytes or platelets. The cultured tumor cellis $\mathbb{M R}-106, B 16$ and 5583 also contalned vitamin $K$ dependent carbaxylase activity. Vitanin $K$ epoxide reductase activity was demonstrated only in cells where vitamin $k$-dependent carboxylase activity was present. The tumor cells possessed remarkably less $K$ epoxide reductase activity than the the normal cells. When cells were cultured in medium contalning warfarin, the $K$ epoxide reductase activity was found to be decreased and the amount of non-carboxylated precursor proteins had increased, suggesting an analogous vitamin $K$ mechanfsm as in liver. 
INTRODUCTION

Vitarlin $K$ acts as a coenzyme in the carboxylation of peptide-bound glutamic actd residues to 4-carboxyglutamic actd residues (Gla), which strongly bind $\mathrm{Ca}^{2+}$-lons. The active cofactor, vitamin $\mathrm{K}$ hydroquinone ( $\left.\mathrm{KH}_{2}\right)$, is formed wa the reduction of vitamin $K$ quinone $(K)$ by one or more reductases. During the carboxylation reaction, $\mathrm{KH}_{2}$ is converted into vitanin $K$ epoxlde (KO) which is reduced again to $k$ by $k 0$ reductase. Anticoagulants of the coumarin type interfere with the formation of Gla by fnldbiting the reductase enzymes (for reviews see refs " $1,2,3$ ). It has been suggested that comarin derivatives may also inhibit the formation of cumor metastases, but the antimetastatic activity may not necessarily occur via interference wh the vitamin $\mathrm{K}$ cycle (4).

Vitamin $K$ dependent carboxylase activities have been denonstrated in the microsomal fractions of varlous tissues, including tumor tissue $(2,3,5)$. Recenty we have also shown the presence of coumarin sensitive ko reductases in rat hepatic and various non-hepatic tissues (6). Obviously all these preparations contain a variety of cells. To study the role of vitamin $k$-dependent enzymes in tumor metastasis and in other processes, it is necessary to know in which type of cells these enzymes are present. Usting the technique commonly employed for the determination of vitamin $K$-dependent carboxylase in microsomal fractions, a fairly large quantity of cells is needed. Therefore we adapted this method to measure directy witamla $K$-dependent carboxylase activity in a relatively snall number of cells. Varlous typeg of cells were examined subsequently for their vitamin K-dependent enzymatic activities.

\section{MATERIALS AND METHODS}

\section{Reagents:}

Water-solubillzed vitamin $K$ (Konakion ${ }^{\mathbb{R}}$ ) was obtained from Hoffman-La Roche (Switzerland) and vitamin $\mathrm{KH}_{2}$ was prepared as described earlier (7). Pure vitamin $K$ was obtained from Merck (F.R.G.) and witamin Ko was prepared from it according to the method of Tischler (8). Warfarin, dithiothreitol (DTT), tocopherolacetate, $N-2$-hydroxyethylpiperazine-N'-2-ethane sulfonate (HEPES) 
and 3-([3-cholamidopropyl] dimethylamonio)-1-propane sulfonate (CHAPS) were purchased from Sigma (U.S.A.). The synthetic substrate Phe-Leu-GiuGlu-Leu (F L E E L) was obtained from Vega Biochemical Co. (U.S.A.), $\mathrm{NaH}^{14} \mathrm{CO}_{3}(50-60 \mathrm{CH} / \mathrm{mol})$ from Amershat (U.K.) and Atomlight from New England Nuclear (F.R.G.). Fetal calf serum (FCS) was obtalned from Seromed (F.R.G.) and Dulbecco's MEM culture mediun and Hank's ballanced salt solution were from Gibeo (U.K.). All other chemicals were obtained from Merck (F.R.G.)

Cells :

The cell lines UMR-106 (rat osteosarcoma), 5583-83 (human colon carcinoma) and B 16-F10 (mouse melanoma) were propagated in our laboratory as monolayers in Falcon $\mathrm{T} 25$ tissue culcure medium plus respectively $5 \% \mathrm{FCS}$, $10 \%$ FCS and $10 \%$ FCS plus 25 mM HEPES. The other cells were kfndly provided by various laboratories. Endothelial cells were isolated from human umbilical veins and cultured as described by Willems et al. (9). Renal tubular cells from monkey and from dog were 1solated and cultured according to van Wezel et al. (10). Osteoblasts were isolated from rat calvarta and cultured as described by Boonekamp et $a 1$. (11). For some experiments cells were cultured in the presence of warfarin (100 ug/ml medium). After harvesting, the cells were washed 3-4 times with PBS and counted before the cell pellets were frozen at $-80^{\circ} \mathrm{C}$. Hepatocytes were isolated from perfused rat livers according to Groen et al. (12). The purity of these cells was $>95 \%$. Three batches of hepatocytes (from three different livers) were mixed and used in the experiments described below. Macrophages were isolated from rat spleens as described by Muller et al. (13). Platelets and Iymphocyteg. were isolated from the buffy coats obtained from blood of healthy male donors according to Bevers et a1. (14). After counting, all cells were frozen at $-80{ }^{\circ} \mathrm{C}$. Biefore freezing the viability of the cells, as estimated by occlusion of trypan blue, was $>90 \%$. After thawing a11 cell pellets were resuspended in buffer A ( $1 \mathrm{M} \mathrm{NaCl}, 50 \mathrm{mM} \mathrm{Tr}$ is/HCl, pH 7.4, $20 \%$ ethyleneglycol) to a final concentration of $10^{7}$ cells/mi. The cell mixtures were sonicated before use.

\section{Vitamin $\mathrm{K}$-dependent carboxylase assay:}

The vitamin $K$-dependent carboxylation of F L E E L wais measured by incubating $\pm 10^{6}$ lysed cells in buffer $A$ with $F$ L E L (10 mM), vitamin $\mathrm{KH}_{2}(0.2 \mathrm{mM}), \operatorname{DTT}(4 \mathrm{mM}), \mathrm{NaH}^{14} \mathrm{CO}_{3}(0.02 \mathrm{mCl}),\left(\mathrm{NH}_{4}\right)_{2} \mathrm{SO}_{4}$ (1 M), phosphatidylcholine $(50-200 \mu g)$ and the detergent CHAPS $(50-200 \mu g)$. The 
optimal phosphatidylcholine and CHAPS concentrations had to be checked for each batch of cells. Phosphatidylcholine was added as mixed micelles of the phosphollpid wh cholate $(1: 1, w / w)$. Incubation was performed in 0.25 inl reaction mixtures at $25^{\circ} \mathrm{C}$ for vartous time intervals. The reaction was stopped and non-bound ${ }^{14} \mathrm{CO}_{2}$ was removed by adding 1 ml trichloroacetic acid $(5 \%$ w/v) followed by degassing the reaction mixture for 3 min at elevated temperatures. The samples were supplemented with $10 \mathrm{ml}$ Atomilight and counted in a Beckman scintullation counter. To measure the amount of non-carboxylated precursor proteins (endogenous substrate) 2-3.10 $0^{6}$ cells were incubated wth only $\mathrm{KH}_{2}$, DTT and $\mathrm{NaH}^{14} \mathrm{Ca}_{3}$ in buffer A for 60 min. In all experiments, parallel incubations were performed in the absence of $\mathrm{KH}_{2}$ and DTT. These blank values were subracted.

Vitamilin ko reductase assay:

The ko reductase activity was measured essentially as described earlier (6) With adaptations for the use of a small amount of cells per incubation (15). In short, $0.5-1.10^{6}$ lysed cells were pre-incubated in buffer $A$ in 0.1 ml inixtures with DTT (10 mM) for 3 min at $37^{\circ} \mathrm{C}$. The reaction was started by adding $4 \mu \mathrm{g}$ KO in $2 \mu 1$ propano1-2. After 1 h the reaction was stopped by adding $0.9 \mathrm{ml}$ propanol-2 contalning $2.5 \mu \mathrm{g}$ tocopherolacetate as an Internal standard. The mixture was extracted with $0.6 \mathrm{ml}$ hexane and 0.5 m1 $0.01 \mathrm{M} \mathrm{AgNO}_{3}$ to prevent co-extraction of DTT. The hexane phase was washed with $0.5 \mathrm{ml} 0.4 \% \mathrm{NaCl}$ and evaporated to dryness at $35^{\circ} \mathrm{C}$ under a stream of nitrogen. The residue was dissolved in 50 pll propanol-2 and the vitamin $K$ content was deternined using KLLC analysis.

\section{RESULTS}

To Investigate the presence of vitamin K-dependent systems in cultured calls we adapted our vitamin K-dependent carboxylase assay in such a way that the vitanin $\mathrm{K}$-dependent ${ }^{14} \mathrm{CO}_{2}$ incorporation could be measured directly in an amount as small as $10^{6}$ cells. The optimal CHAPS and phosphatidy1choline concentrations may vary per type of cell. In general, both inhibit at higher concentrations. The addition of $\left(\mathrm{NH}_{4}\right)_{2} \mathrm{SO}_{4}$ stimulates the ${ }^{14} \mathrm{CO}_{2}$ incorporation into $F L E \mathbb{E} L$ at least four times. A time course of the viltamin $\mathrm{K}$-dependent carboxylation by various types of cells is shown in fig. 1 . 


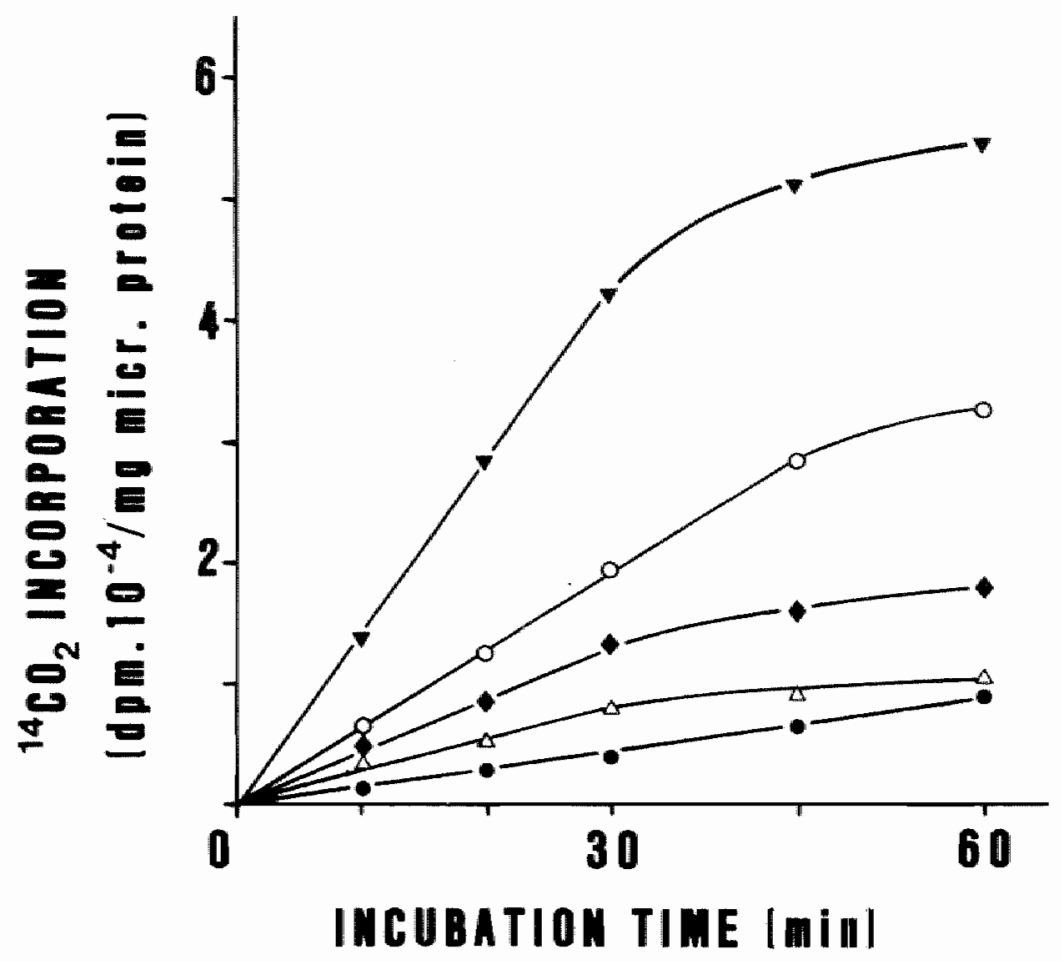

Pig. 1.

Time course of vitamin $K$ dependent incorporation of ${ }^{14} \mathrm{CO}$, into $L E E L$ by various celle. The aarboxilation reaction was perfomed for various time intervals under standard conditione. Explanation of symbole:

$\boldsymbol{\nabla}-\boldsymbol{\nabla}$ hepatooytes;

$\rightarrow$ UMR celto

- renal tubular cellu

o-o endothetial celle

From a number of different cells the vitamin $k$-dependent-carboxylase activity was measured (table I). It will be obvious that vitamlm $\mathrm{K}$-dependent carboxylase is present in all cells tested, except in platelets and 1 ymphocytes. In these cells vitamin $K$-dependent carboxylase activity could nat even be demonstrated when $\pm 5.10^{7}$ cells were used for one incubation.

To Investigate the presence of other enzymes of the vitanin $k$ cycle in cells, we also measured vitamin ko reductase activity. Vitamin ko reductase 
Table I

Vhamln $K$ dependent carboxylase activity in varlous cells

type of cell
${ }^{14} \mathrm{CO}_{2}$ incorporation 1 into F L E E L
(dpm/10 $60^{6}$ ce 11 s)

$-\mathrm{KH}_{2}-\mathrm{KH}_{2}$

hepatocytes ( $\mathrm{rat}$ )

42900

330

renal tubular cells (monkey)

4700

3810

6785

1320

19700

350

400

13125

8060

4.125
280

250

270

260

330

330

410

260

280

200

Vitamin $\mathbb{K}$-dependent earboxylation was performed under standard conditons in the presence and absence of witan $\mathbb{K H}_{2}$ and $\mathrm{OTT}$. Carboxylase activity igg expressed as dpm ${ }^{4} \mathrm{CO}_{2}$ incorporated $\mathrm{in}{ }^{2} \mathrm{~F}$ L $\mathbb{E}$ E L per $30 \mathrm{~min}$ per $+10^{6}$ cells. The values are the average of triplicate measurements.

activity was only demonstrated in cells where vitamin $K$-dependent carboxylase activity was present (table II). In general, tumor cells produced a lesser amount of vitamin $K$ quinone than the non-tumor celis, indicating that their vitamin ko reductase activity is less active. No correlation was found between the relative values of vitamin $K$-dependent carboxylase activity and vitamin $k$ reductase actiwlty as measured in vitro. Such a correlation was neither found in the microsomal fractions of various rat tissues $(6)$. 
Table II

Vitamin ko reductase activity in various cells

\begin{tabular}{lr}
\hline Type of cell & pmol vitamin $K$ \\
hepatacytes & $250-300$ \\
renal tubular celis (ape) & $185-240$ \\
renal tubular cells (dog) & $220-235$ \\
endothelial cells & $90-180$ \\
UMR & $9-12$ \\
B 6 & $7-17$ \\
5583 & $11-20$
\end{tabular}

Vitamin ko reductase activity was measured in $0.5-1.10^{6}$ gells. The enzymatic activity is expressed as pmol vitamin formed per $10^{6}$ cells per hour. The data give the range between varlous batches of cells.

When animals are treated with warfarin an accumulation of non-carboxylated precursor proteins can be detected in liver and in various non-hepatic tissues. These precursor proteins are called the "endogenous substrate" for carboxylase. We cultured some types of cells in the presence of warfarin and compared their content of non-carboxylated precursor protelns with the amount in corresponding normal cultured cells (table III). In all cases a small but distinct increase of the amount of nonmarboxylated precurgor proteins could be observed. The values are in the same order of magnttude as the accumulation found for non-hepattc rat tissues after coumarin treatment. In liver, howewer, a least a tenfold increase in non-carboxylated precursor proteins has been reported (6).

To determine whether the incorporated label could be Identifled as Gla, the varjous ${ }^{14} \mathrm{C}-1$ abeled reaction products were heated at $110^{\circ} \mathrm{C}$ in $6 \mathrm{M} \mathrm{HCL}$ for $24 \mathrm{~h}$. Since Gla-residues are acid-labile, the theoretical losis of ${ }^{14} \mathrm{CO}_{2}$ during this treatment is $50 \%$. The observed losses were $44 \%$ in the case of B.16 cel1s, 57\% with UMR-106 cells, $59 \%$ with 5583 cells and $48 \%$ with the endothelial cells. From these results we concluded that under our experimental conditions Gla-residues had been formed by all four cell. lysates. 
Table III

Intluence of warfarin in cell culture medium on the atount of non-carboxylated precursor proteins

type of cell

accumulation $(\%)$

(amount without warfarin $=100 \%$ )

$\begin{array}{lll}\text { BI6 } & 185 & (170-201) \\ \text { UMR } & 320 & (230-405) \\ 5583 & 140 & (114-163) \\ \text { endothelial cells } & 170 & (148-192)\end{array}$

The amount of non-carboxylated precursor proteins was measured in $2-3.10^{6}$ cells. The values after culturing on warfarin-containing medium 100 ug warfarin per mil) are expressed as a percentage of the corresponding amounts in the same quantity of normal cultured cells. The data are the mean of duplicate measurements using two parallel batches of cells. The range between the different preparations is given in parentheses.

Table IV

Influence of warfarin in cell culture medium on the vitamin ko reductase activity

type of cell vitamin ko reductase activity (\%)

(activity without warfarin $=100 \%$ )

\begin{tabular}{lll}
\hline B16 & 28 & $(18-37)$ \\
UMR & 35 & $(29-42)$ \\
5583 & 30 & $(28-33)$ \\
endothelial cells & 70 & $(59-80)$
\end{tabular}

Vitamin ko reductase activity was measured in $\pm 10^{6}$ cells. The values obtained from cells cultured on a warfarin containing medium are expressed as a percentage of the vitanin ko reductase activity found in a same quantity of corresponding cells cultured on a normal medium. Data are the mean of duplicate measurements. The range between the different preparations is given in parentheses. 
As warfarin is thought to block vitamin ko reductase in liver, we investigated the activity of this enzyme in cells cultured on a warfarin-containing medium. In all cases the vitamin ko reductase activity was diminished as compared to the corresponding values in normal cultured cells (table IV). Tumor cells appeared to be more sensitive for warfarin than normal endothelial cells.

\section{DISCUSSION}

In this paper we describe a method for measuring witamin K-dependent carboxyllase activity directly in a relatively small quantity of cells $(n=$ about $10^{6}$ ). Using this method, we have shown that vitamin $K$-dependent carboxylase is present in various types of isolated and cultured cells. We could also detect vitamin Ko reductase in these cells. As the experimental exror in counting of the cells is about $20 \%$, the values given are only indicative. These observations confirm the presence of vitamin K-dependent enzymes in many non-hepatic tissues as was shown before (3,6). In general, the function of the vitamin $K$-dependent enzymes in the non-hepatic cells is not yet completely clear. Probably all these enzymes will produce Glacontaining proteins. As yet the synthesis and secretion of Gla-containing proteins have been described for only some types of cells. Osteoblasts are suggested to produce asteocalcin, a protein that might be involved in the regulation of bone mineralization (16). Nishimoto and Price demonstrated that this bone-Gla protein ls also produced by rat osteosarcoma cells (17). Endothellal cells are believed to produce the Gla-containing protein $s$ (18). Protein S is also secreted by platelets (19), however we could not detect any vitamin $\mathrm{K}$-dependent enzymatic activity in platelets. Therefore, protein $S$ may be synthesized in the megakaryocytes before platelets are produced by fragmentation. Macrophages, which contalin carboxylase in small but detectable amounts, show procoagulant activity (13) and the syathesis of the clotting factors II, VII and $X$ has recently been demonstrated in these cells $(20)$.

The proteins which may be synthesized in the other cells have not yet been detected. Gla-containing protedns dissimilar of the coagulaton factors and osteocalcin however, have been demonstrated in renal stones 
(21), In urine (22), in speri cells (23), in calcifled shin nodules (24) and in atherosclecotic plaques (25). Further research concerning these nom-hepatic Gla-containing protelns and their place of synthesis are in currenty progress in our laboratory.

Buchtal et al. previously showed vitamin $\mathrm{K}$-dependent carboxylase activity in milnosomes from tumor tissue (5). This activity was not necesarily due to tumor cells, but could also be ascribed to for instance vitand K-dependent activity in the vessel wall. Our results clearly confirm now the presence of vitamin $K$-dependent enzymes in warious tumor cells.

The relation between the inhibition of tumor metastases by warfarin and the vitamin $k$-dependent enzymes is not clear at this noment. In this connection it may be worth noting that tumor cells showed a remarkably lower Wtamin $k$ epoxide reductase activity than the non-tumor cells, while the vitanin $K$-dependent carboxylase activities were found to be within the same range. Moreover the turmor cells seemed to be silightly more sensitive for warfarin treatment as compared to the endothelial cells. A comparison between vitamin $K$-dependent reactions in tumor- and non-tumor cells from the same origine will probably give us more lnsight in the signifleance of the vitanin $K$-dependent enzymes for tumor metastases.

\section{Acknowledgements}

The authors wish to thank Drs. M.P.M. Herrmann-Erlee, A.J. Meyer, A.D. Muller, H.A.P. Pols, J.L.M.L. van Rijn, C.A.M. v.d. Velden-de Groot and P.B. van Wachem for kindly supplyling us with cells, Mrs. M.J. DrittyRelnders for her skilfuli. technical assistance, Dr. H.C. Heraker for his sttmulating discussions and mrs. M. Molenaar-v.d. Voort for typing this manuscrlpt. This study was supported by grant MD 82145 from the Tromboseatichting Nederland.

\section{REFERENCES}

1. Suttle, J.W., Ann. Rev. Biachem. 54: 459-477, 1985

2. Vermeer, C., De Boer-van den Berg, M.A.G., Haematologla 18: 71-97, 1985

3. Vermeer, C. Mol. Cell. Biochem. 61: 17-35, 1984

4. Zacharskl, L.R., Henderson, W.G., Rlchler, F.R. et al., JAMA 245: $831-835,1981$

5. Buchtal, S.D., McAllister, C.G., Laux, D.C., Bell, R.G., Biochem. Biophys. Res. Commun. 1.09: 55-62, 1982 
6. De Boer-van den Berg, M.A.G., Thijssen, H.H.W., Vermeer, C., Biochim. Biophys. Acta $884: 150-157,1986$

7. Vermeer, C., Soute, B.A.M., De Metz, M., Henker, H.C., Biochitu. Biophys. Acta 714: 361-365, 1982

8. Tishler, M., Fieser, L.F., wendler, N.L. J. Am, Oll Chex. Soc. 62: $2866-2871,1940$

9. N1liems, Ch., Astald1, G.C.B., de Groot, Ph.G., Janssen, M.C., Gonsalvez, M.D., Zeylemaker, W.P., van Mourik, J.A., Van Aken, W.G., Exp. Cel1 Res. 139: 191-197, 1982

10. Van Wezel, A.L., van der Velden-de Groot, C.A.M., van Herwarden, J.A.M., Developments of Biologicall Standardization (Karger, S. ed.) Wo1. 46, pp. 151-158, 1980

11. Boonekamp, P.M., Hekke1maa, J.W., Hamilton, J.W., Cohn, D.V., Jilka, R. L., Proc. Kon. Ned. Akad. Wetensch. 87: 371-381, 1984

12. Groen, A.K., Sips, H.J., Vervoorn, R.C., Tager, J.M., Eur. J. Biochem. $122: 87-93,1982$

13. Muller, A.D., van Dan-Mieras, M.C.E., Hemker, H.C. Haenostasis 15. $108-113,1985$

14. Bevers, E.M., Confurius, P., Zwaal, R.F.A., Biochim. Blophys. Acta 736 : $57-66,1983$

15. Dritty-Reynders, M.J.H.J., Hoeymakers, J.J.F., Thijssen, H.H.M., Uitendaal, M.P., Proc. Brit. Pharm. Soc. 93 p (abstr.), 1986

16. Beresford, J.N., Gallagher, J.A., Poser, J.W., Russell, R.G.G., Metab. Bone Dis. and Rel. Res. 5: 229-235, 1984

17. Nishimoto, S.K., Price, P.A., J. Bilol. Chem. 260: 2832-2836, 985

18. Fair, D.S., Marlar, R.A., Levin, E.G. Blood 67: 1168-1171, 1986

19. Schwarz, H.P., Heeb, M.J., Wence1-Drake, J.D., Griffin, J.H., Blood 66: $1452-1455,1985$

20. Dsterud, G., Lindah1, U., Seljel1d, R., FEBS Lett. 120: 41.-43, 1980

21. Lian, J.B., Prien, E.L., Glimcher, M.J., Gallop, P.M., J. Clin. Invest. 59: $1151-1157,1977$

22. Nakagawa, Y., Abran, V., Kézdy, F.J., Kaiser, E.T., Coe, F.L., J. Biol. Chem. 258: 12594-12600, 1983

23. Soute, B.A.M., Müller-Ester1, W., De Boer-Van den Berg, M.A.G., U1rich, M., vermeer, C., FEBS Lett. 190: 137-141, 1985

24. Lian, J.B., Skinner, M., Glimcher, M.J., Gallop, P., Blochem. Biophys. Res. Commun. 73: $349-355,1976$

25. Levy, R.J., Harvard, S.L., Dshry, L.J., Atherosclerosl.g 59: 155-160, 1986 



\section{VITAMIN K-DEPENDENT ENZYMES IN CULTURED CELLS FROM HUMAN ARTERIAL AND VENOUS VESSEL WALL}

M.A.G. de Boer-van den Berg, L.J.M. van Haarlem and C. Vermeer

\section{SUMMARY}

The presence of vitamin $K$-dependent carboxylase 1 s demonstrated in both human arteries and velns. The enzymatic activity per mg milcrosomal proteln in atherosclerotic arteries $(N=8)$ was 1 ess than $25 \%$ of the activity in non-affected arteries $(N=3)$. Vitamin $K$-dependent carboxylase activity was also present in cultured arterial and venous endothelial cells, and in cultured smooth muscle cells. Also vitamin $\mathrm{K}$ epoxide reductase activity and vitamin $K$ quinone reductase activity were found in these cella, which indicates that vitamin $k$ can be recycled in the cells. When venous endothelial cells were cultured on a warfarin-containing medium the reductase activities had decreased and the amounts of non carboxylated precursor proteins had increased, indicating that coumarlos inhibit the vitamin $\mathrm{K}$-dependent carboxylation fin human endothelial cells. 


\section{INTRODUCTION}

Vicamin $K$ l.s involved in the carboxylation of spectific glutamic acid residues (G1u) to 4-carboxyglutatic acid residues (Gla). The active cofactor in the carboxylation reaction, vitamin $K$ hydroquinone $\left(\mathrm{KH}_{2}\right)$ is formed via the reduction of vitamin $K$ quinone $(K)$ by one or more $K$ reductases. In vitro DTr may serve as a cofactor for these enzymes. During carboxylation, vitamin $\mathrm{KH}_{2}$ is converted to vitamin $\mathrm{K}$ epoxide (Ko) which is reduced again to vitamin $K$ by the DTT-dependent ko reductase. The only known function of Gla 18 a strong interaction wh Ca ${ }^{2+}$ ions $(1-3)$. The coagulation factors II, WII, $I X$ and $X$ and the coagulation inhibiting protelns $C$ and $S$ are examples of Gla-contalning proteins. During the last 10 years other Gla-containing proceins, dissinllar to the (anti-)coagulation factors have been detected. One of them is osteocalcin which may play a role 1 in bone mfneralization. This protein, purlfied from the bone of varlous spectes and from the media of cultured rat osteosarcona cells, has been well characterized $(4,5)$. In vitro it prevents the precipitation of calchum phosphate from a supersaturated solution, while the decarboxylated form does not, suggesting that Gla-residues are involved in this inhibitory effect $(6,7)$. Other Glamcontaining proteins which, like osteocalcin, may play a role in the deposition of calciun salts have been demonstrated in kldney stones ( 8 ), skin noduli ( 9 ) and atherosclerotic plaques (10). The in vivo function of these proteins is not yet clear and neither we know the place where they are synthesized. Probably also in these proteins the formation of Glamesidues occurs via a vitamin K-dependent process. Witam K-dependent carboxylase activity has been demonstrated earlier in the microsonal fractions of varlous tissues of different species, including the bovtne aorta (11). Here we report the presence of the vitamin $K$-dependent enzymes in human arterles and veins. Recently we described a modiflcation of our vitamin $K$-dependent carboxylase assay to measure directly vitamin K-dependent ${ }^{14} \mathrm{CO}_{2}$ incorporation in a small amount of cells (12). Using this method we also investigated the presence of vitamin $\mathrm{K}$-dependent enzymes in cultured cells which normally form part of the vessel wall i.e. endothelial cells and smooth muscle cells. 
MATEERIALS AND METHODS

\section{Chemicals:}

Pure witamin k was obtained from Merck (F.R.G.) and vitam KO was prepared from it according to the method of Tischler (13). Water-solubilized vitamin $\mathbb{K}$ (Konakion ${ }^{R}$ ) was obtained from Hoffmam-la Roche (Switzerland) and vitumin $\mathrm{KH}_{2}$ was prepared as described earlier (14). The synthetic substrate Phe-Leu-Glu-Glu-Leu (F L E E L) was purchased from Vega Biochemical Co (U.S.A.), $\mathrm{NaH}^{14} \mathrm{CO}_{3}(50-60 \mathrm{Ci} / \mathrm{mol})$ was from Amersham (U.K.) and Atomlight was from New England Nuclear (F.R.G.). Fetal calf serum was obtalned trom Seromed (F.R.G.) and Dulbecco's MEM culture medium and Hank's balanced salt solution were from Gibco (U.K.). Warfarin, dithlothreitol (DTT), tocow pherolacetate, and 3-([3-cholamidopropy 1$]$ dimethyl amonio)-1-propane sulforate (CHAPS) were purchased from Sigma (U.S.A.). All other chemicals were obtained from Merck (F.R.G.).

\section{Methods :}

Pieces of human aorta, vena cava and varicose veins were obtained from the departments of Surgery and Pathology of the Academic Hospital in Maastricht and the Slotervaart hospital in Amsterdar. It was ascertalned that all material was frozen at $-80{ }^{\circ} \mathrm{C}$ immediately after surgery and at last within 3 hours after death. The aortae were divided into atherosclerotic and non-atherosclerotic ones according to the pathologlst's opinton. Three non-atherasclerotic tissues were obtained from young men, who died after craffic accidents. Most of the tissues were obtained from aged people. The varicose veins $(n=3)$ were obtained from people aged between 35 and 50 years. After thawing, the tissues (10-30 g each) were stripped of fat and cut into small pieces before they were homogenized in a Breda Scientiflc blender, with 2-3 volumes of buffer A $0.1 \mathrm{M} \mathrm{NaCl}, 50 \mathrm{mM}$ Tris/HCl, pH 7.4, $20 \%$ ethyleneglyco 1 ). The mixture was centrifuged for 10 min at 8000 at 10 ${ }^{\circ}$ C. The supernatant was kept and the preclpltate was mixed again with 2 volumes of buffer $A$ and recentrifuged for $10 \mathrm{~min}$ at $8000 \mathrm{~g}$. The jolned supernatants were used for the preparation of the microsomall fraction by centrifuging the mixture for $1 \mathrm{~h}$ at $100000 \mathrm{~g}$ at $4^{\circ} \mathrm{C}$. The microsomal pellet was resuspended in buffer $A$ and centrifuged again unt 1 the supernatant was colourless ( $1-2$ washing cycles). A final wash step was performed in buffer B (buffer A, contalning $1 \mathrm{M}$ NaCl Instead of $0.1 \mathrm{M}$ MaCl). Afterwards the 
microsomal pellet was resuspended in a small wolume of buffer $B$ to a protelin concentration of 7-12 mg per ml, frozen ln liquid nitrogen and stored at $-80{ }^{\circ} \mathrm{C}$ unt 1 use. No measurable $10 s s$ in activity was found for at Least 2 months.

All cells were kindly provided by various laboratories. Endothelial and smooth muscle cells were isolated from human umbilical cord arteries and veltas and cultured as described by willems et al. (15). For some experiments, cells were cultured in the presence of warfarin $(100 \mu \mathrm{g} / \mathrm{ml}$ medium). Endotheltal cells from canine femoral arteries and veins were 1solated and cultured as described by Groenewegen et a1. (16). After harvesting, the cells were washed 3-4 times with PBS and counted before the cell pellets were frozen at $-80^{\circ} \mathrm{C}$. The viability, as estimated by occlusion of trypan blue, was $>90 \%$ in all cells tested. Hepatocytes were isolated from perfused rat livers according to Groen et al. (17), counted and frozen at $-80^{\circ} \mathrm{C}$. Their purity was $>95 \%$. After thawing, all cell pellets were resuspended in buffer $B$ to a final concentration of $10^{7}$ cells/ml. The cell mixtures were sonicated before use.

Vitanin $K$-dependent carboxylation was performed as described earlier for microsomes (18) and cells (12), by measuring the incorporation of ${ }^{14} \mathrm{CO}_{2}$ into the synthetic substrate F L E E L. Per incubation 1 mg microsomal proteins or $10^{6}$ cells were used. The carboxylation reaction was started by adding either vitamin $\mathrm{KH}_{2}$ or vitamin $\mathrm{K}+$ DTT. As vitamin $K$ has to be converted into $\mathrm{KH}_{2}$ before carboxylation can take place, the activity of the DTt dependent $k$ reductase enzyme can be measured wia this reaction. To measure the amount of membrane-bound non-carboxylated precursor proteins (the somcalled endogenous substrate) the $\mathrm{KH}_{2}$-dependent carboxylation was performed in the absence of the exogenous substrate F L E E L. The amount of ${ }^{14} \mathrm{CO}_{2}$ lncorporated in the trichloroacetic actd-precipltable fraction is considered as a measure for the number of the membrane bound precursor protelins. In all carboxylation experiments, parallel incubations were performed in the absence of $K$ and DTT. These blank values were subtracted. The DrT-dependent $k 0$ reductase activity was measured essentially as described earlier $(12,18)$. One mg of microsomal proteins of $10^{6}$ cells were incubated For $30 \mathrm{~min}$ at $30^{\circ} \mathrm{C}$ in the presence of $4 \mu \mathrm{g}$ KO and $10 \mathrm{mMTT}$ and the amount of vitanin $K$ quinone formed is considered to be a measure for the enzyatic activity. Protein concentrations were determined according to Sedmak and Grossberg (19). 


\section{RESULTS}

$\mathrm{KH}_{2}$-dependent ${ }^{14} \mathrm{CO}_{2}$ incorporation was measured in the microsomal fractions from human arteries and veins. A typical time course for both tissues is shown in fig. 1 . In the presence of the synthetic substrate F L E E L, the reaction proceeded in a linear way until $30 \mathrm{~min}$. A rather small amount of endogenous substrate could be demonstrated in both tissues (fig : 1).

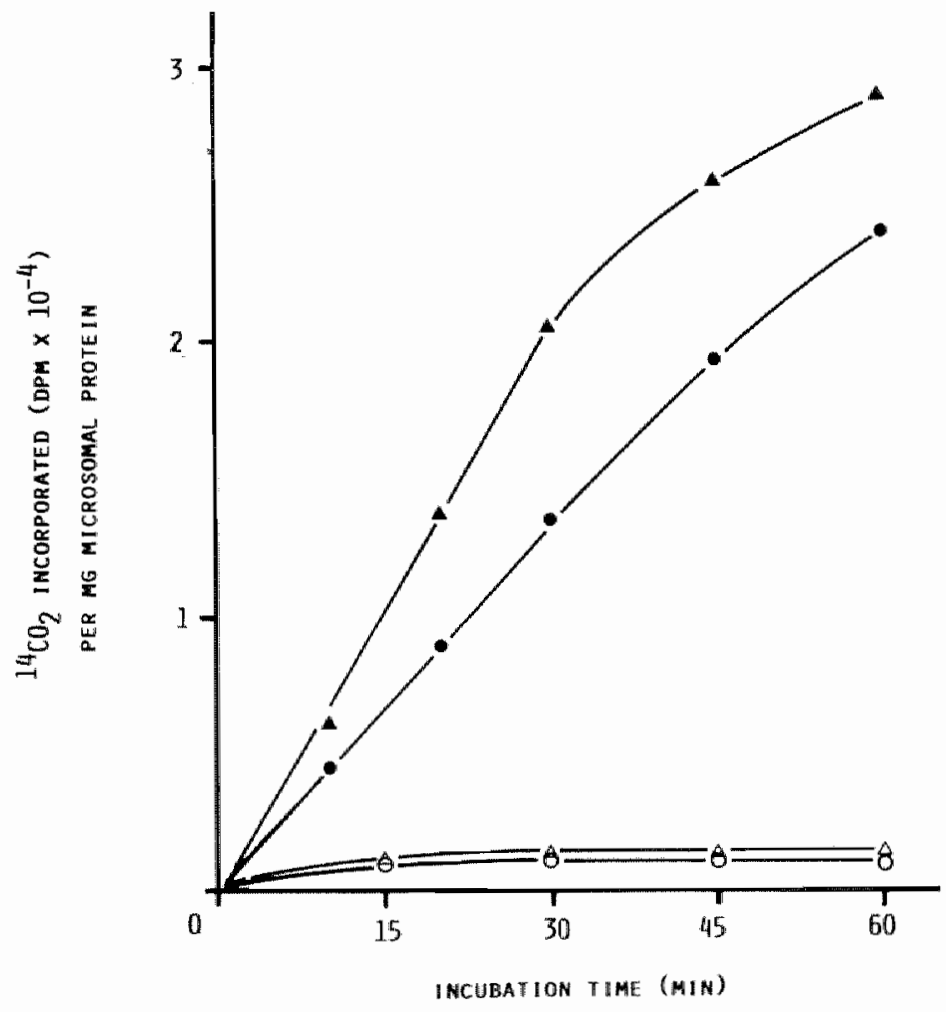

Fig. 1 .

Time course of the carboxylation by microcomal preparations from human

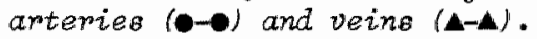

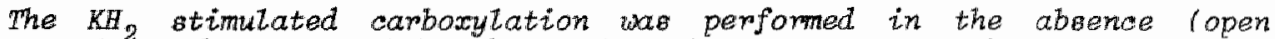
symbols) and preaence (closed symbote) of the exogenous oubstrate $P L E L$ (10 mW). Blank values, demived from parallel incubations without $\mathrm{KH}_{2}$ and DTT ranged between 200 and $400 \mathrm{dpm}$ and were subtracted. 
No substantial differences were found between the carboxylation activities In microsomal preparations from the vena cava $(600 \pm 100 \mathrm{dpm} / \mathrm{min}$ per $\mathrm{mg}$ mfcrosomal protein, $n=4)$ and from the varicose veins $(570 \pm 80 \mathrm{dpm} / \mathrm{min}$ per mg fuicrosomal protein, nus 3 ).

A substantial difference in the $\mathrm{KH}_{2}$-dependent carboxylase activity per mg onfcrosomal proteln was found between non-atherosclerotic and atherosclerotic arteries. The enzymatic activities in the microsomal fractions from the last ones ( $n=8)$ were less than $25 \%$ of the activities found in the preparations from three non-affected tissues (fig. 2A). Differences were also found in $k 0$ reductase activities ( $f$ ig* 2B).

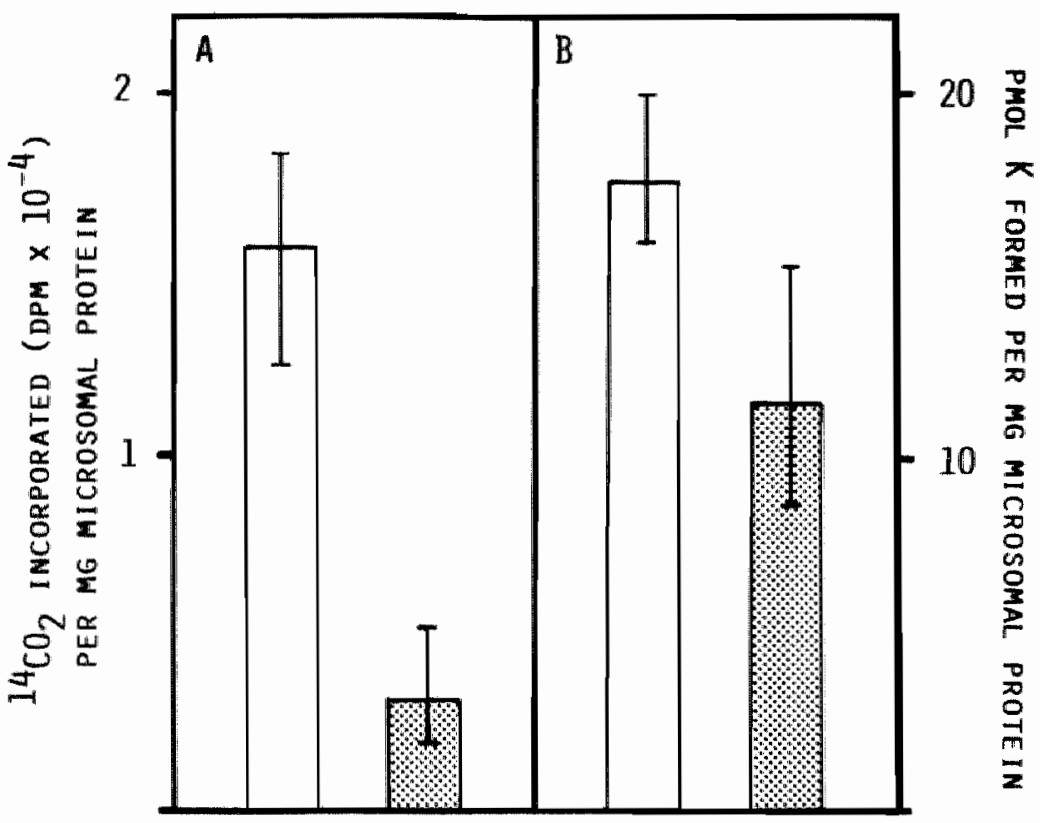

Fig. 2 .

Comparison between miorosomal preparatione from atherocclerotic and non-atheroolerotic tiasuea.

A: $K H_{2}$ stimulated carboxylation of $F L E E L$; open bar: non-atherosclerotic tisave $(n=3)$, grey bar: atheroscterotic tissue $(n=8)$. Median and extreme valuse are given.

B: KO reductase activity, open bar: non-atherosclerotic tisate $(n=3)$; grey bar: atherosolerotio tussue $(n=5)$. Median and extreme values are given. 
To detect which type of cells in the vessel wall contain vitamin K-dependent enzymes, cultured endothelial cells and smooth muscle cells both derived from umbilical cord arteries and veins, were examined on their vitamin K-dependent enzymatic activities. In all cells tested, $\mathrm{KH}_{2}$-dependent carboxylase activity was present (table I).

Table I

Vitamin $k$-dependent enzymatic activities in cultured arterial and venous cells

\begin{tabular}{|c|c|c|c|}
\hline type of cells & $\begin{array}{l}\mathrm{KH}_{2} \text {-driven } \\
\text { carboxylation } \\
\left({ }^{14} \mathrm{CO}_{2} \text {-bound }\right)\end{array}$ & $\begin{array}{l}{[\mathrm{K}+\mathrm{DT} \mathrm{T}] \text {-driven }} \\
\text { carboxylation } \\
\left({ }^{14} \mathrm{CO}_{2} \text {-bound }\right)\end{array}$ & (pmol $\mathrm{k}$ formed) \\
\hline
\end{tabular}

Arterial endo-

thellal cells

6270

2400

94

Venous endo-

thelial cells

5270

141

Arterial smooth

muscle cells

7110

2810

110

Venous smooth.

muscle cells

8980

3670

117

Rat hepatocytes

24400

10980

300

The $\mathrm{KH}_{2}$-stimulated carboxylase actiultes and the [K HTT] stimulated carboxylase activities are given as the amount of ${ }^{14} \mathrm{CO}_{2}$ incorporated into $\mathbb{F} E E L$ in $30 \mathrm{~min}$. Blank values, obtalned from pârallel incubations without $\mathrm{K}$ and DTT, rangedl between $200-400 \mathrm{dpm}$ and were subtracted. The ko reductase activities are given as the amount of pmol $K$ formed during $30 \mathrm{~min}$ of incubation. All reaction mixtures contalned $10^{\circ}$ cells. "The data are the average of triplicate measurements. Variances between the experiments were less than $15 \%$.

We could also demonstrate DTT-dependent ko reductase activity and $[\mathrm{K}$ \# DTT'-stimulated carboxylase activity in these cells (table I). From these results we concluded that all cells tested contain the enzymes requited for 
an tefledent recycling of vitamin $k$. Wost of the experiments concerning vitam k-dependent enzymes have been performed with rat or bowne liver microsomes. Therefore we have included in table $I$ the vitain $k$-dependent enzymatc actitules as measured in a same quantity of isolated rat hepatocytes. The hepatocytes contained 2.5 to 4 thes more vitamin K-dependent enzymatc activities than the cells from vessel wall. These data are comprable with those found in hepatic and non-hepatic tisstes (18).

Not anly cells derived from the vessels of the umbilical cord contaln vtam K-dependent enzymes. Also endothellal cells cultured from canine femoral arteries and velns showed $\mathrm{kH}_{2}$-dependent carboxylase activity: the wenous cells contatined $\pm 35 \%$ and the artertal cells $\pm 50 \%$ of the enzymatic activity in rat hepatocytes.

Coumarln drugs like warfarta prevent the formation of Gla-residues in proteins produced by livet tissue. The comarins inhibit the DTT-dependent Ko reductase and the DTT-dependent $k$ reductase steps in the vitamin $k$ cycle, resulting in a decreased production of the active cofactor in carboxylation, $\mathrm{KH}_{2}$. To investigate the effect of warfarin on the vitamin K-dependent enzymes in verous endothelial cells, warfarin was added to the culture medium $(100 \mu \mathrm{g} / \mathrm{m} 1)$ for 3 to 5 days. This warfarin concentration did not apparenty alter the normal pattern of cell growth. At higher concentrations (> $200 \mu \mathrm{g} / \mathrm{ml}$ ) the cells stopped growing and finally died. As compared to the activities in normal cultured cells, the DTT-dependent Ko reductase activity and the $[K+D T T\}$-stimulated carboxylase activity were decreased, whlle the $\mathrm{KH}_{2}$-dependent carboxylase activity was increased (table IC). We also found an increase in the amount of endogenous substrate. To determine whether $\left[{ }^{14} \mathrm{C}\right]-G 1$ a was formed in the precursor protelns, incubated samples of warfarin-treated cells were heated at $110{ }^{\circ} \mathrm{C}$ in $6 \mathrm{MHCl}$ for $24 \mathrm{~h}$. ThHs treatment resulted in a loss of $48-54 \%$ of the bound ${ }^{14} \mathrm{C}$. As the theoretical loss of ${ }^{14} \mathrm{C}$ from $\left[{ }^{14} \mathrm{C}\right]$ Gla, labeled in one of the carboxylgroups, would be $50 \%$ we concluded that Gla-residues had been formed by the endothelial cell preparations. 
Effects of warfarin in the cuiture medium on the vitamin $K$-dependent activities in endothelial cells

parameters measured

quantities

(percentage of normal values)
Ko reductase activity
$70-72 \%$
$[\mathrm{K}+\mathrm{DTT}]$-driven carboxylase activity
$63-74 \%$
$\mathrm{KH}_{2}$-driven carboxylase activity
$13.4-143 \%$
amount of endogenous substrate
$178-206 \%$

In parallel experiments, cells were cultured with and withowt warfarin (100 $\mu \mathrm{g} / \mathrm{ml}$ culture medium). All data obtained from cells after warfarin treatment, are expressed as a percentage of the corresponding normal values. The ranges between a triplicate series of experiments are given.

\section{DISCUSSION}

Vitamin $k$ dependent enzymes were shown to be present in arterlal and venous endothelial cells and in smooth muscle cells. From the data in this paper, it can be concluded that warfarin influences the vitamin $K$ cycle in human endothelial cells in a similar way as it inhibits the vitamin $k$-dependent enzymes in bovine and rat llwer. Low dose orall coumarin treatment of rats resulted in a decrease of DTT-dependent ko reductase activities in liver and in several non-hepatic tissues (18). It seems probable, therefore, that also in patients under coumartn-anticoagulant therapy, the DTT dependent $\mathrm{KO}$ - and $K$ reductase activities will be decreased in endothelial cells. As comparable vitamin $K$ dependent systems are present in smooth muscle cells, we presume that the carboxylation of proteins in these cells will also be affected by coumarin treatment. Before we can speculate about possible effects of this inhibition we have to know which proteins are carboxylated in vivo by these cells. Endothellal cells are believed to produce the anti-coagulation factor protein $S(20)$, but the protein(s) which may be synthesized by smooth muscle cells have not yet been detected. Whereas in an earlier paper vltamin $K$-dependent carboxylase 
could ondy be demonstrated in arteries and not in veins (11), improved homogenlzation procedures and a far more sensitłwe carboxylase assay have enabled us also to demonstrate unequivocally the presence of the enzyme in vellng.

Unt11 now, we lave no explanation for the fact that atherosclerotic tisures seem to contain less $\mathrm{KH}_{2}$-dependent carboxylase activity per rog microsomal protein than the non-affected tissues. However, the rather low carboxylase activity may result in an undercarboxylation of secreted Gla-contalning proteins, which may influence their $\mathrm{Ca}^{2+}$-binding capacity* In analogy with osteocalcin, the undercarboyxlation might interfere with the prevention of Ca-salts from a supersaturated solution. In vivo this night contribute to the formation and/or maintenance of atherosclerotic plaques .

\section{Acknowledgements}

The authors wish to thank Drs. W.A. Buurman, Ph.G. de Groot, V. wan Hinsbergh, A.J. Meyer and P.B. van Wachem for kindly supplying us with cells, the staff of the departments of Surgery and Pathology from the University Hospital in Mastricht and the Slotervaart Hospital in Amsterdam for their cooperation in obtaining luman arterial and venous tissues; Dr. H.C. Hemker for his sttmulating discusstons and mrs. M. Molenaar-v.d. Voort for typing this manuscript. This study was supported by grant MD 82145 from the Trombosestichting Nederland and by grant 13-50-52 from the Division for Health Research TNO.

\section{REPERENCES}

1. Vermeer, C. and de Boer-v.d. Berg, M.A.G. Haematologia 18: 71-97, 1985

2. Olgon, R.E. Ann. Rev. Nutr. 4: 281-337, 1984

3. Suttle, J.W. Ann. Rev. Blochem. 54: 459-477, 1984

4. Poser, J.h., Esch, F.S., Ling, N.C. and Price, P.A. J. Biol. Chem. 255, $8685-8691,1980$

5. Nishimoto, S.K. and Price, P.A. J. Blol. Chem. 255: 6579-6583, 1980

6. Price, P.A., Otsuka, A.S., Poser, J.W., Kristaponis, J. and Raman, N. Proc. Nat1. Acad. Scit. USA 73: 1447-1453, 1976

7. Vermeer, C., Soute, B.A.M., Ulrtch, M.M.W. and v.d. Loo, P.G.F. Haenostasis 16: $246-257,1986$

8. Lian, J.B., Prien, E.L., Glimcher, M.J. and Gallop, P.M. J. C1in. Invest. 59: 1151-1157, 1977

9. L.tan, J.B., Skinner, M., Glimcher, M.J. and Gallop, P. Biochem. Blophys. Res. Conmun. 73: 349-355, 1976

10. Levy, R.J., Lian, J.B., Gallop, P. Biochem. Biophys. Res. Commun. 91: $41-49,1979$ 
11. Vermeer, C., Hendrix, H. and Daemen, M. FEBS Lett. 148: 317-320, 1982

12. De Boer-v.d. Berg, M.A.G., Vitendal, M.P. and Vermeer, C. Mollec. Cell. Bíochem. (in press)

13. Tishler, M., Freser, L.T., Wendler, N.L. I. Am. Oil Chem. Soc. 62: $2866-2871,1940$

14. De Metz, M., Vermeer, C., Soute, B.A.M. and Henker, H.C. In: Witamin $K$ metabolism and vitamin $\mathrm{K}$ dependent Protelns (Suttle, J.W. ed), pp 560-570, University Park Press, Baltimore, 1980

15. Willems, Ch., Astaldi, G.C.B., de Groot, Ph.G. Janssen, M.C., Gonsalvez, M.P., Zeylemaker, W.P., van Mourik, J.A, and van Aken, W.G. Exp. Ce11. Res. 139: 1.91-197, 1982

16. Groenewegen, G., Buurman, W.A. Jeumhome, G.M.A.A., van der Linden, C.J., Vegt, P.A. and Kootstra, G. Transplantation 37: 206-210, 1984

17. Groen, A.K., Sips, H.J., Vervoorn, R.C. and Täger, J.M. Eur. J. Biochem. 122: $87-93,1982$

18. De Boer-v.d. Berg, M.A.G., Thijssen, H.H.H. and Vermeer, C. Biochim. Biophys * Acta 884: 150-157, 1986

19. Sedmak, J.J. and Grossberg, S.E. Anall. Biachem. 79: 544-552, 1977

20. Fair, D.S., Marlar, R.A., Levin, E.G. Blood 67: 1168-1171, 1986 

SOME CHARACTERISTICS OF VITAMIN K-DEPENDENT CARBOXYLASE IN HUMAN TISSUES

M.A.G. de Boer-van den Berg and C. Vermeer

\section{SUMMARY}

Vitanin K hydroquinone-dependent carboxylase activity is demonstrated In the microsomes from human kidney, lung, spleen and testis and the characteristics of these systems are compared with those of the human liver enzyme. The pentapeptide $F \mathbb{L} E \mathbb{E}$, descarboxyprothrombin fragment 1.3-29, decarboxylated sperm-Gla-protein and decarboxylated osteocalctin could be used as exogenous substrates for all five types of carboxylase, but the relative carboxylation rates differed from one tissue to another. DTT-dependent $v i t a m i n ~ K$ reductase was tested by replacing vitamin $k$ hydroquinone by vitamin $K$ quinone $+D T T$ in the carboxylase assay and the presence of the enzyme was established in all tissues examined. In the presence of vitamin $\mathrm{K}$ quinone + DTT the carboxylation reaction was lnhibited for $50 \%$ by warfarin concentrations between 2 and $15 \mathrm{pM}$. WADH did not enhance the [vitamin $k$ quinone + DTT]-stimulated carboxylation reaction. 
INTRODUCTIOM

Vitamin $K$-dependent carboxylase is a microsomal enzyme system involved In the postranslational conversion of glutamic acid residues into 4-carboxyglutamic acid (Gla) residues in proteins (1-3). Vitamin $k$ in its hydroquinone form $\left(\mathrm{KH}_{2}\right)$ is the active cofactor in this reaction and during the carboxylation it is converted into vitamin $K 2,3$ epoxide (Ko). A second enzyme, the dithlothreltol-dependent ko reductase (4) is able to reduce $k 0$ into vitanin $K$ quinone $(K)$, which is subsequently reduced further to $\mathrm{KH}_{2}$ by two or more $K$ reductases, one of which is -at least in vitro- dithiothreitol (DTL) dependent, the other one(s) MADH dependent. The physlological counterpart of DTT in the two DTT-dependent enzymes mentioned above is presently unknown. Coumarin derlvatives like warfarln primarily inhibit the DrT-dependent reductases, which results in a decreased production of $\mathrm{KH}_{2}$ and thus in an impaired Gla formation.

For a long time it has been thought that vitamin K-dependent carboxylase was exclusively located in the liver, where it is inwolved in the synthesis of the blood coagulation factors II, VII, IX and $X$ and the anticoagulation proteins $\mathrm{C}$ and $\mathrm{S}$. Later on it was demonstrated in experimental animals that the formation of Gla-residues is a far more common process, occuring in many other tissues as well (5-7). Evidently the results of these animal studies should be verifled with human tissues. Until now the only data avallable have been obtained from human liver $(8,9)$ and placenta $(8,10)$, skin (11) and vessel wall (12). In this paper we compare the vitamin K-dependent enzymes from huran liver with those from human kldney, lung, spleen and testis.

\section{MATERTALS AND METHODS}

\section{Chemicals}

Vitamin $\mathbb{K}\left(\right.$ Konakion $^{\mathrm{R}}$ ) was obtained from Hoffmann-La Roche (Switzerland) and vitamin $\mathrm{KH}_{2}$ was prepared by chemical reduction (13). $\mathrm{NaH}^{14} \mathrm{CO}_{3}(50-60$ Ci/mol) was purchased from Amersham (U.K.) and Atomlight from New England Nuclear (F.R.G.). NADH and subtilisin were obtained from Boebringer Mannheim (F.R.G.) and warfarin, dithiothreitol (DTT) and 3-([3-cholamido- 
propyl]dimethyl ammonio)-1-propane sulfonate (CHAPS) from Sigma (U.S.A.). The pentapeptide Phe-Leu-GIu-Glu-Leu (F L E E L) was from Vega Blochemical Co (U.S.A.). Human prothrombin was kindly supplied by dr. G. Tans from our institute. Antibodies against native human blood coagulation factors IT, VII, IX and $X$ as well as those against the native human protelns $C, S$ and $\mathbb{Z}$ were generous gifts from $d r$. R. Bertina (Leiden, The Netherlands). The antibodies had been tmmuno-purifled and linked to CNBr-activated Sepharose. All other chemicals were of the highest quality commercially awatlable.

\section{Protein substrates}

Decarboxylated osteocalcin was prepared from bovine bone (14) and decarboxylated sperm-Gla-protein from human spermatozoa (15). The proteolytic subtilisin split product fragment 13-29 (fragment Su) was prepared from human prothrombin in a similar way as it was described for bovine descarboxyprothrombin (16). The peptide was then converted into a carboxylatable substrate by thermal decarboxylation of its Gla-residues (17), which facilitated its detection during the subsequent purffication steps.

Preparation of microsomes.

Piece of human liver, kidney, spleen, lung and testis ( $10 \mathrm{~g}$ each) were obtained from the Departments of Pathology of the University Hospital in Maastricht and the Slotervaart Hospital in Ansterdam. All material was obtained from obduction at last within 3 hours after death. Tissues were obtained and experiments performed after written permission from the Ethical Board of the University of Maastricht. After thawlng, the tissues were carefully cleaned and cut into small pleces before they were homogenized in a Breda Sclentiflc mixer with $2-3$ wolumes of buffer A $(0.11 M$ NaCl, $50 \mathrm{mM}$ Tris/HCl, $\mathrm{pH} 7.4,20 \%$ ethyleneglycol, $2 \%$ Trasylol). Corresponding tissues from five different donors were pooled before homogentzation. The microsomal fractions were prepared by different centrifugation (12). The final washed microsomal pellet was resuspended 1 n buffer $B$ (buffer $A$, containing $1 M \mathrm{NaCl}$ instead of $0.1 \mathrm{M}$ NaC1), frozen In 1fquid nitrogen and stored at $-80^{\circ} \mathrm{C}$ unt11 use. No measurable loss in activity was found for at least 6 months.

Vitamin $K$-dependent activities.

Vitamin $\mathrm{K}$-dependent carboxylation of exogenous substrates was performed as described earlier (7). Vitamin $\mathrm{KH}_{2}$ was used as a coenzyme and all reaction mixtures contained I mg of microsomal proteins, $8 \mathrm{mM}$ DTT, $0.2 \%$ CLAPS (w/v), 
$0.01 \mathrm{mCl} \mathrm{NaH}^{14} \mathrm{CO}_{3}, 0.2 \mathrm{mM}$ vicamin $\mathrm{KH}_{2}$ and an exogenous substrate, e.g. F L E E L (4 mM); decarboxylated osteocalcin $(0.02 \mathrm{mH})$; decarboxylated subtlikin split product 13-29 from prothrombin (0.02 mM) or decarboxylated sperm-Glamprotein $(0.2$ a M). The enzymatic activity is expressed as dpm incorporated $\mathrm{CO}_{2}$ per min per mg proteln.

DTT dependent vitamin $K$ reductase activity was measured in a similar way by replacing vitamin $\mathrm{KH}_{2}$ by vitamin $K$ and by usling $4 \mathrm{mM} F \mathrm{~F} E \mathbb{E} L$ as the exogenous substrate.

In some experiments $2 \mathrm{mM}$ NADH was added to the vitamin $\mathrm{K}$ containing reaction mixture, the DTT concentration was than lowered to $5 \mathrm{~m}$ or oritited.

Non-carboxylated precursor protelns were quantitated by performing the Wtamin $\mathrm{KH}_{2}$-dependent reaction in the absence of exogenous substrate. Under these conditons the amount of ${ }^{1 / 4} \mathrm{CO}_{2}$ fixed may be regarded as a measure for the amount of endogenous substrate present in the microsomes. In all carboxylation experiments, parallel incubations were performed in the absence of vitamin $K$ and DTr. These bllank values were subtracted.

\section{other methods}

Protein concentrations were determined according to Sedmak and Grossberg (18).

Sepharose bound antibodies against human native coagulation factors II, VII, $I X$ and $X$ and protein $C, S$ and $Z$ were used to extract the endogenous substrate proteins from the hepatic microsomal fraction, after vitamin $\mathrm{KH}_{2}$ dependent ${ }^{14} \mathrm{CO}_{2}$ incorporation had occurred. The extraction procedure was essentially similar as described before for bovine liver microsomes (19).

\section{RESULTS}

Washed mlcrosomes were prepared from human liver. 1ung, spleen, kidney and testls. In these samples we have tried to identify and partially characterize two enzymatic reactions, which both play a role in the formation of Gla-residues in proteins.

$\mathrm{KH}_{2}$-dependent carboxylase was tested in the presence of witamin $\mathrm{K}$ hydroquinone and $F L E E L$ and the carboxylation rate observed under these conditons was arbitrarily taken as a measure for the amount of carboxylase 
Table: I

Amounts of vitamin $\mathrm{KH}_{2}$-dependent carboxylase activity and amounts of endogenous substrate in different tissues

\begin{tabular}{lrc}
\hline Tissue & $\begin{array}{c}\text { Carboxylase activity } \\
\text { (dpa/min per mg protein) }\end{array}$ & $\begin{array}{c}\text { Endogenous substrate } \\
\text { (dpm per mg protein) }\end{array}$ \\
\hline liver & 2800 & 1900 \\
kidney & 720 & 370 \\
lung & 540 & 425 \\
spleen & 100 & 385 \\
testis & 535 & 370
\end{tabular}

Vitamin $\mathrm{KH}_{2}$-dependent carboxylase activities were measured in the picrosomal fraction of various tissues. The values are expressed as dpm ${ }^{4} \mathrm{CO}_{2}$ incorporated into F L E E L per min per mg microsomal protein. Blank values, ranging between 6 and 17 dpm per min per mg microsomal protein were subtracted. The amounts of endogenous substrate were measured by performing the carboxylation reaction 14 the absence of exogenous substrate. The values are expressed as $\mathrm{dpm}{ }^{14} \mathrm{CO}_{2}$ incorporated per mg microsomal protefin. Blank values, ranging between 10 and 30 dpm per mg microsomal protein, were subtracted. All data are the means of duplicate measurements. Vartations were less than $10 \%$.

present. In all cases the reaction occurred with a constant rate for at least $30 \mathrm{~min}$. The dat obtalned are summarized in table I and it is clear: that vitamin $\mathrm{KH}_{2}$-dependent carboxylase activicy was present in all tisisus examined.

Microsome-bound non-carboxylated precursor protelns which in vitro function as an endogenous substrate for carboxylase, may be detected under similar conditions as described above, but in the absence of $F$ L E E $\mathbb{L}$. Aa is shown in table $\mathbb{I}$ also the presence of endogenous substrate could be established in all preparations. We have tried to ldentify the carboxylatable proteins in human liver microsomes in a similar way as it was performed for bovine liver (19): after the in vitro carboxylation of endogenous substrate had been completed the reaction mixtures were extracted with Sepharose-bound immuno-purified antlbodles agalnst each of the native human coagulation factors $I L, V I I, I X$ and $X$ as well as the proteins $C, S$ and $Z$, and it was investigated to which extent the 
Table II

Vitamin $\mathrm{KH}_{2}$-dependent carboxylase activity towards three different substrates by various tissues

\begin{tabular}{|c|c|c|c|}
\hline TLEBe & d-osteocalcin & d-fragment Su & d-sperm Gla-protein \\
\hline 11wer & $100 \%$ & $100 \%$ & $100 \%$ \\
\hline kidney & 37 & 37 & 27 \\
\hline lung & 15 & 29 & 18 \\
\hline spleen & 7 & 30 & 11 \\
\hline tegtis & 13 & 43 & 22 \\
\hline
\end{tabular}

Vitamin $\mathrm{KH}_{2}$-dependent carboxylase activity was measured towards three different substrates. The data are expressed as a percentage of the corresponding carboxylase activity in liver mfcrosomes. The carboxylase activities in liver, expressed as the amount of ${ }^{4} \mathrm{CO}_{2}$ incorporated per min per mige microsomal proteln are 760 dpm for d-osteocalcin, 325 dpm for d-fragnent $S u$ and 425 dpm. for d-sperm-Gla-protein, fragment Su stands for the subtilisin split product of human prothrombin, containing the aminoaclds 13-29; d- stands for decarboxylated. Blank values, ranging between 4 and $1.6 \mathrm{dpn}$ per min per mg microsomal proteln were subtracted. The data are the average of duplicate measurements, in which the variations were less than $12 \%$.

Table III

Inhibition by warfarin of the vitamin $K+D T T$ dependent carboxylation

\begin{tabular}{|c|c|c|}
\hline Tissue & $\begin{array}{c}{[K+\text { DTT }] \text {-dependent }} \\
\text { carboxylase activity } \\
\text { (dpm/mtm, per mg protein) }\end{array}$ & $\begin{array}{l}\text { Warfacin concentration } \\
\text { ( } \mathrm{MM}) \text { required for } \\
50 \% \text { inhibition) }\end{array}$ \\
\hline Liver & 1800 & 3 \\
\hline kidney & 230 & 15 \\
\hline lung & 215 & 15 \\
\hline spleen & 85 & 5 \\
\hline testis & 230 & 2 \\
\hline
\end{tabular}

Vtramin $K+$ DTT-dependent carboxylase activitles were measured in the picrosomal fractions of various tissues. The values are expressed as dpm ${ }^{4} \mathrm{CO}_{2}$ incorporated into $\mathrm{F} L \mathrm{E}$ E L per min per mg microsomal protein. Blank values, ranging between 4 and $10 \mathrm{dpm}$ per min per mg microsomal protein were subtracted. Warfarin was added in a concentration range between 1.0 and 32 $\mu M$. The data are the mean of duplicate measurements. Variations were less than $10 \%$. 
${ }^{14} \mathrm{C}$-labeled reaction products had bound to the various immobilized antibodies. In contrast to the bovine system, however, the labeled human precursor protains exhibited no affinity towards one of the antibodies used.

Since substantial differences have been found between the substrate specificities of carboxylase from different bovine tissues (20), we have also checked if a similar phenomenon could be established for the human enzy'teses.

We therefore have measured the substrate specificity of the five types of carboxylase using three different protein substrates: decarboxylated sperm Gla-protein, decarbaxylated prothrombin fragment 13-29 (both of human origin) and decarboxylated osteocalcin from bovine bone. Although some differences were found between the substrate carboxylation in the vartous microsomes (table II), the amounts of tissue available did not allow us to quantify these differences by determining the $k_{m}$ values for each of the substrates in all carboxylase preparations.

For the detection of DTT-dependent vitamin $\mathrm{K}$ quinone reductase (another enzyme of the vitanin $K-c y c l e)$, the carboxylase assay was modifled by replacing vitamin $\mathrm{KH}_{2}$ by vitamin $\mathrm{K}+$ DTT. In the system thus obtalned vitamin $K$ has first to be reduced to vitamin $\mathrm{KH}_{2}$ before it can serve as a cofactor for carboxylase. In this way also the DTT-dependent $K$ reductase could be demonstrated in all tissues examined (table III). Vitamin K-antagonists of the coumarin type, like warfarin, are well known inhibitors of DTT-dependent $k$ reductase in liver and we hawe investigated if the reductases from other tissues were simliarly sensitive towards this drug. Obviously the IC-50 values for warfarln were measured in the lvitamin $\mathrm{K}+\mathrm{DTT}$-dependent system and the results are summarlzed in table III. As compared to the data in bovine systems (5) the IC-50 walues obtalned with the human microsomes were rather low. Even at high warfarin concentrations ( $1 \mathrm{mM}$ ), however, in all tissues a residual carboxylase activity (ranging from 10-20\% of the non-inhibited enzymes) was found.

Finally we have also investigated the presence of NADH-dependent vitamin $K$ reductase, using the conditions described by Wallin $(9)$. In the experimental set-up the [uitamin $k+$ DTrl-dependent carboxylation is performed in the presence and in the absence of NADH and the difference between the two activities is defined as the NADH-dependent reductase 
activt.y. In none of the microsomal preparations this enzymatic activity could be detected, however. The activity could neither be demonstrated when the carboxylation was performed in the presence of vitamin $\mathrm{K}+$ NADH only.

\section{DISCUSSION}

In thls paper we describe the occurrence of vitam $\mathrm{KH}_{2}$-dependent carboxylase and DTT-dependent $K$ reductase in the microsomal fractions of human lityer, kidney, lung, spleen and testis. If expressed per mg of microsomal protein both enzymes are most abundantly present in the liver. In the non-hepatic tissues, the $\mathrm{KH}_{2}$-dependent carboxylase activity ranged between 10 and $30 \%$ from those in liver, dependent on the substrate used, whereas the DMT-dependent $K$ reductase activity was found to be $5-15 \%$ from the activity measured $1 n$ liver. It is striking that in spleen microsomes, the carboxylation of the endogenous substrate as well as that of descarboxy subtiliain fragment 13-29 was comparable with that of the other non-hepatic tissues, whereas the carboxylation of the other substrates $(F \mathbb{E} E \mathrm{E}$, d-osteocalcin and d-sperm Gla-protein) is 5-10 times lower "This might suggest that also in man vitamin $\mathrm{KH}_{2}$-dependent carboxylases from different tissues have different substrate specificities.

I.t was checked that the donors of the tissues had not been treated with vtanin Kantagonists. Nevertheless non-carboxylated endogenous substrate was found to be present $\mathbb{1 n}$ the various microsomal fractions. This phenomenon was demonstrated earlfer for rat tissues (7).

ALL DTT-dependent $K$ reductases were inhibited by warfarin. The warfarin concentration required for $50 \%$ Inhlbition of the [K + DTT stimulated carboxylation ranged between 2 and $15 \mu$. In general less warfarin was needed for the in vitro inhibition of human $K$ reductases than for the corresponding bovine enzymes (5). It is noteworthy that we were unable to completely inhibit the reductase reactions. Even at warfarin concentrations as high as 1 mM a residual enzymatic activity of $10-20 \%$ was found.

We could not confirm the results of Wallin and Martin (9) who recently reported the existence of a $\mathrm{NADH}-d$ ependent vitamin $K$ reductase in human liver microsomes. These authors found a stimulation of the lvitamin $K+$ 
DTTl-driven carboxylation after adding $2 \mathrm{mM}$ NADH to thelr reacton mixtures. We have not found such a stimulation in one of the tissues ewen not at low DTT concentrations. The different results obtained by both groups may be the result of different procedures used for the preparation of the microsomes. After our extensive washing procedure no MADH-dependent K reductase activity was found in microsomes from human tissues, so we may assume that this enzyme originates from the cytosol instead from the microsomal membrane.

\section{Acknowledgements}

The authors wish to thank the staff of the department of Pathology from the Uniwersity Hospital in Mastricht and the Slotervaart Hospital in Amsterdam for their cooperation in obtaining human tissues. Dr. R. Bertina for supplying us with Sepharose-bound antibodies, Dr. G. Tans for supplying ws with huma prothrombin, Drs. H.C. Hemker and H.H.W. Thijssen for their stimulating discussions, ars. M. v.d. Heijden for her excellent technical assistance and mrs. M. Molenaar-v.d. Voort for typing this manuscript. This study was supported by grant MD 82145 from the Trombosestichting Nederland.

\section{REFERENCES}

1. Vermeer, C. Molec. Cell. Biochem. 61: 17-35, 1984

2. Suttie, J.W. Ann. Rev. Biochem. 54: 459-477, 1985

3. 01son, R.E. Ann. Rev. Nutr. 4: 281-337, 1984

4. Suttie, J.W. and Preusch, P.C. Haemostasis 16: 193-215, 1986

5. Vermeer, C., Hendrix, H. and Daemen, M. FEBS Lett. 148: 317-320, 1982

6. Buchta1, S.D. and Be11, R.G. Biochemistry 22: 1077-1.082, 1983

7. De Boer-van den Berg, M.A.G., Thifssen, H.H.W. and Vermeer, C. Blochlm. Biophys. Acta $884: 150-157,1986$

8. Soute, B.A.H., De Metz, M. and Vermeer, C. FEBS Lett. 146: 365-368, 1982

9. Wallin, R. and Martin, L.F. J. Clin. Invest. 76: 1879-1884, 1985

10. Friedman, P.A., Hauschka, P.o., Shla, M.A. and Wallace, J.K. Blochlo. Biophys. Acta 676: 101-107, 1979

11. De Boer-van den Berg, M.A.G., Verstijnen, C.P.H.J. and Verneer, C. J. Invest. Dermatol. $87: 377-380,1986$

12. De Boer-van den Berg, M.A.G. and Vermeer, C. This thesis, chapter 9

13. De Metz, M., Vermeer, C., Soute, B.A.M. and Hemker, H.C. In: Vitamin K metabolism and vitamin $K$ dependent proteins (Suttie, J.W. ed.) pp. $560-570,1980$ University Park Press, Ba1timore

14. Vermeer, C., Soute, B.A.M., Hendrix, H. and De Boer-van den Berg, M.A.G. FEBS Lett. 165: 16-20, 1984

15. Soute, B.A.M., Muiller-Esterl, H., De Boer-van den Berg, M.A.G., U1rich, M. and Vermeer, C. FEBS Lett. 120: 137-141, 1985

16. Soute, B.A.M., Vermeer, C., De Metz, M., Hemker, H.C. and Lljnen, H.R. Biochim. Blophys. Acta 676: 202-207, 1981 
17. Poser, J.W. and Price P.A. J. Biol. Chers. 254: 431-436, 1979

18. Sedmak, J.J. and Grossberg, S.E. Anal. Biochern. 79: 544-552, 1979

19. De Hetz, M. , Wermeer, C., Soute, B.A.M., Van Scharrenburg, G.J.M., Sllotboon, A.J. and Heniker, H.C. FEBS Lett. 123: 215-218, 1981

20. Ulelch, M.M.M., Soute, B.A.M., De Boer-van den Berg, M.A.G. and Vermeer, C. Blochirit. Biophys. Acta 830: 105-108, 1985 


\title{
THE IN VIVO EFFECTS OF 4-HYDROXYCOUMARIN DERIVATIVES ON HUMAN HEPATIC AND NON-HEPATIC VITAMIN K-DEPENDENT ENZYMES
}

\author{
M.A.G. de Boer-van den Berg and C. Vermeer
}

\section{SUMMARY}

The in wivo effects of oral anticoagulant therapy with 4-hydroxycoumarins on various vitamin $K$-dependent enzyme systems in man were compared. In hepatic microsomes abtained from donors who had been treated with 4-hydroxycoumarins for more than 6 months, the vitamin $K 2,3$ epoxide reductase activity and the DTT-dependent vitamin $K$ quinone reductase activity, were diminlshed to $35 \%$ and $20 \%$ of the corresponding normal. values. In the non-hepatic tissues, only a small decrease in vitamin $K 2,3$ epoxide reductase activities could be demonstrated, whlle no differences were found in the vitamin $K$ quinone reductase activities. In none of the tissues, a significant increase of non-carboxylated precursor proteins was. observed, whereas also vitamin $K$ hydroquinone-dependent carboxylase activities seemed to be unaffected by the anticoagulant treatment. 
INTRODUCTION

VLtanta $K$ is involved in the posttcanslational conversion of specific glutante acta residues into 4-carboxyglutanc acid (Gla) residues (1-3). This reacton is catalyzed by vitanin k-dependent carboxylase, located at the Lumal side of the endoplasnic reticulum. The active cofactor in the carboxylation reaction, wtamin hydroquinone $\left(\mathrm{kH}_{2}\right)$, can be formed from Witamin $k$ quinone by two or nore reductases, one of wich is -in vitrodithlothreitol (DTT)-dependent, the other(s) MADH dependent. Durlng carboxylation wtamin $\mathrm{KH}_{2}$ is converted 1nto vitamin $\mathrm{K} 2,3$ epoxide (ko) which is subsequent 1 reduced to vitamin $K$ by vitamin $K$ epoxlde reductase which in witro may use DTT as a reducing cofactor. The physilological counterpart of DTH lim these reactions is not yet hown. 4-Hydroxycoumarin derlvatlves are believed to luhlbit the Dip-dependent reductase-steps (4). The result of this linlbitlon ls that the supply of witamin KH. is exhausted, which leads to a decrease of the carboxylation tate. Tn vivo, this sequence of events results in the appearance of mon-carboxylated coagulation factors in the blood stream. These descarboxyfactors do not contaln the ca ${ }^{2+}$ binding Gla-residues and hence they have no biological activity.

lïor many years it has been thought that vitamin k-dependent carboxylase exclusively occurred in the liver where it is involved in the fomation of the coagulation factors II, VII, IX and X. Administration of 4-hydroxycoumatin drugs has been used frequently for the control of blood coagulation during thrombagenic eplsodes. In the last lo years it became evident from antimal studes that vitamin kudeperdent carboxylation also occurred in many non-hepatic tissues like kidney, lung, testes and spleen $(5,6)$. Recently, we also demonstrated the presence of witami K-dependent carboxylase actlvity in nom-hepatic tissues from human orlgin (7-9). Probably, all these non-hepatic witamin k-dependent enzymes will produce Gla-containing protelns, some of which have already been isolated and charatertzed e.g.: osteocalcin, isolated from human bane (10) and sperm-Gla-protedn 1solated from human spermatozoa (1.1).

In an earlier study we have reported the effects of the administration of Low doses of warfarin, acenocounarol and phenprocoumon to rats (12). The 4-hydroxycoumarin treatment resulted in a decrease of vitamin ko reductase 
activity in the various non-hepatic tissues, whereas also a small increase in the amounts of non-carboxylated precursor proteins was observed. In liver, both effects were more pronounced than in the non-hepatic tissues. From these data it seems probably that 4-hydroxycoumarins will also affect the non-hepatic vitamin $\mathrm{K}$-dependent enzymes in man and hence may lead to an undercarboxylation of the non-hepatic Gla-containing proteins. We have tested this hypothesis and the results of our investigations are presented in this paper.

\section{MATERIALS AND METHODS}

\section{Chemicals .}

Water-solubilized vitamin $K$ (Konakion ${ }^{R}$ ) was obtained from Hoffmann-La Roche (Switzerland) and vitamin $K$ hydroquinone was prepared by chemical reduction (13). Pure vitamin $K$ was obtalned from Merck (F.R.G.) and vitamin $K$ 2,3-epoxide was prepared from it according to the method of Tishler et al. (14). $\mathrm{NaH}^{14} \mathrm{CO}_{3}(50-60 \mathrm{Ci} / \mathrm{mol})$ was purchased from Amersham (U.K.) and Atomlight from New England Nuclear (F.R.G.). Ditthiothreitol (DTT), tocopherolacetate and 3-([3-cholamidopropyl]dimethyl-ammonio)-1-propane sulfonate (CHAPS) were obtained from Sigma (U.S.A.). The synthetic pentapeptide Phe-Leu-GLu-Glu-Leu ( $F$ L E E L) was purchased from Vega Biochemical Co (U.S.A.). All other chemicals were of the highest quality commercially avaliable.

\section{Preparations of microsomes.}

Pieces of human liver, kidney, lung, spleen, testis, artery, vene, heart and femoral muscle tissue were obtalned from the departments of Pathology of the Slotervaart Hospital in Ansterdam, the University Hospltal In Maastricht and the St. Josef Hospital in Kerkrade. All materlal was abtained and frozen at $-80{ }^{\circ} \mathrm{C}$, at last within 3 hours after death. Tissues (10-20 $\mathrm{g}$ each) were obtained from 7 donors who had been treated with acenocoumarol $(n=5)$ or phenprocoumon $(n=2)$. Tissues were also obtained from 11 non-treated donors. The arteries abtained were free from atherosclerotic lesions, according tho the pathologist's opinion. Tissues were obtained and experiments were performed after written permission of the Ethical Board from the University. After thawing, the tissues were carefully cleaned and 
homogenized in a ritier with 2-3 volumes of buffer A $0.1 \mathrm{M} \mathrm{NaCl,} 50$ mM Tris/HCl, pH 7.4, 20\% ethylenglyco1, $2 \%$ Trasylo1). The microsomal fractions were prepared by differential centrifugation as described before (9). After an extensive washing procedure, the mictosomal peliet was resuspended in buffer $B$ (buffer $A$, contalning $1 M N$ NaCl instead of 0.1 M $\mathrm{NaCl}$ ) frozen in liquid nitrogen and stored at $-80^{\circ} \mathrm{C}$ until use. No substantial loss of activity was observed for at least 6 months.

Vitamin $K$-dependent enzymes.

Vitanin $\mathrm{KH}_{2}$-dependent carboxylase activity was measured as described earlier (12). The reaction mixtures contained 1 mg of microsonal protein, $0.2 \mathrm{mM}$ vitamin $\mathrm{K}$ hydroquinone, $4 \mathrm{mM} \mathrm{F} \mathrm{L} \mathrm{E} \mathrm{E} \mathrm{L,} 8 \mathrm{mM} \mathrm{DTT,} 0.2 \%$ CHAPS $(w / v)$, $0.01 \mathrm{mCl} \mathrm{NaH}^{1 / 4} \mathrm{CO}_{3}$ and $1 \mathrm{M}\left(\mathrm{NH}_{4}\right)_{2} \mathrm{SO}_{4}$ in buffer $\mathrm{B}$. Incubations were performed at $25^{\circ} \mathrm{C}$ for $30 \mathrm{~min}$. It was checked that the reaction rates were constant during the whole incubation period. The carboxylase activity is expressed as dpm incorporated ${ }^{14} \mathrm{CO}_{2}$ per min per mg microsomal protein. Similar reaction conditions were used to measure the DTT-dependent vitamin $k$ reductase activity but in that case vitamin $\mathrm{KH}_{2}$ was replaced by vitamin $K$ quinone. The amount of non-carboxylated precursor proteins (endogenous substrate) was measured by performing the $\mathrm{KH}_{2}$-dependent carboxylase assay in the absence of $F$ L E E L and $\left(\mathrm{NH}_{4}\right)_{2} \mathrm{SO}_{4}$. Under these conditions the amount of ${ }^{14} \mathrm{CO}_{2}$ fixed may be regarded as a measure for the quality of non-carboxylated precursor proteins present in the microsomes. In all experiments, parallel incubations were performed in the absence of vitamin $\mathrm{KH}_{2}$ and DTr. These blank values were subtracted. The DTr-dependent Ko reductase activity was measured as described earlier for rat tissues (12). The number of pmol $K$ formed after $30 \mathrm{~min}$ incubation of $1 \mathrm{mg}$ microsomal protein in the presence of vitamin $\mathrm{kO}(4 \mu \mathrm{g})$ and DTT $(10 \mathrm{mM})$ was used as a measure for the enzymatic activity.

protein concentrations were determined according to sedmak and Crossberg (15) and statistical analyses were performed using a one talled. Wilcoxon test. 


\section{RESULTS}

Microsomal fractions were prepared from human liver, lung, spleen, kidney, testis, artery, vene, muscle and heart from normal donors and from donors who had been treated with 4-hydroxycoumarins for a continuous period longer than 6 months immediately preceeding their decease. In these preparations we tried to measure the effects of in vivo oral anticoagulant therapy on vitamin $k$-dependent reactions.

Table I

Vitamin $\mathrm{KH}_{2}$-dependent carboxylase activity in tissues from normal and 4-hydroxycoumrin treated donors

\begin{tabular}{|c|c|c|}
\hline \multirow[t]{2}{*}{ Tissue } & \multicolumn{2}{|c|}{$\begin{array}{l}\text { vitamin } \mathrm{KH}_{2} \text {-dependent carboxylase activity } \\
\text { (dpo per min per mg microsomal protein) }\end{array}$} \\
\hline & non-treated donors & anticoagulant treated donors \\
\hline liver & $3052 \pm 708(n=6)$ & $2806 \pm 770 \quad(n=5)$ \\
\hline kidney & $885 \pm 412(n=10)$ & $878 \pm 4.45(n=6)$ \\
\hline lung & $454 \pm 127 \quad(n=6)$ & $524 \pm 80(n=3)$ \\
\hline spleen & $117 \pm 53(n=8)$ & $187 \pm 141 \quad(n=5)$ \\
\hline testis & $498 \pm 199(n=4)$ & $418 \pm 28(n=3)$ \\
\hline artery & $457+75(n=3)$ & $464 \pm 87(n=3)$ \\
\hline vene & $615 \pm 108(n=3)$ & $748 \pm 89(n=3)$ \\
\hline muscle & $345 \pm 44 \quad(n=3)$ & $371 \pm 50(n=3)$ \\
\hline heart & $118+11 \quad(n=3)$ & $121+26(n=3)$ \\
\hline
\end{tabular}

Vitamin $\mathrm{KH}_{2}$ dependent carboxylase activities were measured in the microsomal fractions of various tissues from normal donors and from donors treated with 4-hydroxycoumarin drugs. Blank values, ranging between 5 and $15 \mathrm{dpm}$ per min per mg microsomal protein, were subtracted. From each sertes of tissues the mean values \pm SD are given. The numbers of tissues examined are given in parentheses. 
Table II

Effect of 4-hydroxycoumartin treatment on the amoun of non-carboxylated precursor protelins

Tissue amount of non-carboxylated precursor proteins
(dpm per mg microsomal protein)

noth-treated donors

anticoagulant-treated

donors

$\begin{array}{lcr}\text { Liver } & 1890 \pm 277 & 2695 \pm 1045 \\ \text { kidney } & 404 \pm 157 & 750 \pm 402 \\ \text { lung } & 354 \pm 82 & 389 \pm 88 \\ \text { spleen } & 332 \pm 112 & 368 \pm 92 \\ \text { testis } & 290 \pm 68 & 335 \pm 106 \\ \text { artery } & 257 \pm 75 & 264 \pm 87 \\ \text { vene } & 478 \pm 134 & 583 \pm 70 \\ \text { muscle } & 410 \pm 71 & 459 \pm 58 \\ \text { heart } & 253 \pm 47 & 284 \pm 35\end{array}$

The amounts of non-carboxylated precursor proteins were measured in the microsomal fractions of various tissues from normal donors and from donors treated with 4-hydroxycoumarin drugs. Blank values, ranging between 20 and $50 \mathrm{dpm}$ per $\mathrm{mg}$ microsomal protein, were subtracted. From each series of tissues the mean values $+S D$ are glven. The number of tissues examined are as Ind icated table $\mathrm{I}$.

In a first experiment, the presence of vitamin $\mathrm{KH}_{2}$-dependent carboxylase activity was measured in the varlous fractions. No substantial differences in activity were found between the mean values obtained in normal and anticoagulant-treated donors (table 1). However, we found a substantial variation between the individual values in each group. These interindividual vactations could not be ascribed to the preparation of microsomes (which all had been prepared parallely) or the carboxylase assay (the variation between duplo experiments 1 s always less than $10 \%$ ).

We also investigated the amounts of non-carboxylated precursor proteins in human microsomes (table 2). Although, as compared to the data obtained 
Table III

Effect of 4-hydroxycoumarin treatement on the DTT-dependent vitarnin $k$ reductase activities.

tis sue

[K+DTT]stimulated carboxylase activity

(dpm per min per ang microsomal protein)

non-treated donors anticoagulant-treated

donors

$\begin{array}{lrr}\text { liver } & 2340 \pm 793 & 495 \pm 175 \\ \text { kidney } & 342 \pm 302 & 303 \pm 129 \\ \text { lung } & 269 \pm 49 & 317 \pm 32 \\ \text { spleen } & 91 \pm 33 & 78 \pm 41 \\ \text { testis } & 255 \pm 90 & 287 \pm 66 \\ \text { artery } & 58 \pm 38 & 64 \pm 35 \\ \text { muscle } & 192 \pm 71 & 183 \pm 60\end{array}$

The DTT-dependent $K$ reductase activitles were measured as [K+DTT] stimulated carboxylase activities in the microsomal fractions of vartous tissues from normal donors and from donors treated with 4-hydroxycoumarin drugs. Blank walues ranging between 5 and $15 \mathrm{dpm}$ per min per mg microsomal. protein, were subtracted. From each series of tissues the mean values + SD are given. The number of tissues examined are as indicated in rable I. The amounts of microsomes obtained from vene and heart tissue, did not permit. us to include them in these expertments.

from the normal donors, the average values of endogenous substrate In microsomes from anticoagulant-treated donors appeared to be slight 1 increased in all tissues, this increase was not statistically signtficant.

As 4-hydroxycoumarins are thought to inhibit both, ko-reductase and the DTT-dependent $K$-reductase, we also Investigated the effects of oral anticoagulant therapy on these reductase-activities. From the experiments it results that the level of DTT-dependent vitamin $K$ reductase was normal for all tissues examined except for liver (table 3). The average value of the activity in liver mlcrosomes from anticoagulant-treated donors was less than $25 \%$ of the corresponding average values from the non-treated ones $(\mathrm{p}<0.05)$. 
Table IV

Effect of 4-bydroxycoumarin treatment on the vitamin ko reductase activities

tis gue

vitamin $\mathrm{KO}$ reductase activity

(ptol K formed per min per mg microsomal protein)

ron-treated donors

ant lcoagulant-treated

donors

$\begin{array}{lll}\text { liver } & 50.5 \pm 11.3 & 17.7 \pm 3.2 \\ \text { kidney } & 18.4 \pm 6.1 & 16.8 \pm 5.7 \\ \text { lung } & 26.1 \pm 8.3 & 16.6 \pm 3.4 \\ \text { spleen } & 13.4 \pm 6.4 & 11.0 \pm 5.7 \\ \text { testis } & 37.6 \pm 17.3 & 24.6 \pm 7.2 \\ \text { artery } & 15.9 \pm 4.3 & 10.7 \pm 2.8 \\ \text { vene } & 11.8 \pm 6.4 & 10.6 \pm 4.1 \\ \text { muscle } & 12.3 \pm 3.1 & 11.8 \pm 2.6 \\ \text { heart } & 16.5 \pm 2.0 & 12.1 \pm 3.7\end{array}$

Vitamin $K$ epoxide reductase activities were measured in the microsomal fractions of various tissues from normal donors and from donors treated with 4-hydroxycoumarin drugs. From each series of tissues the mean values \pm SD are given. 'The number of tissues examined are as indicated in table I.

In a subsequent experiment the presence of vitamin ko reductase in the various tissues was investigated. As is shown in table 4 the enzymatic activtty was present in all tissues examined. The mean values of the witam ko reductase activities in the non-hepatic microsomes from anticaagulant-treated donors showed a conslstent tendency to be lower than In the corresponding tissues from normal donors, but this decrease was not statistically significant. On the other hand, in liver a substantial decreased vitamin ko reductase activity $(p<0.05)$ was demonstrated in the microsomes from the anticoagulant treated donors. 


\section{DISCUSSION}

In this study the presence of vitamin $k$-dependlent enzymes in various human tissues has been confirmed. In general, the relative carboxylation rates are similar to those found for rat tissues; only human spleen tissue contained a remarkable lower carboxylase activity than the rat spleen tissue (12). The vitamin ko reductase activities in microsomes from human tissues were substantially higher than those in corresponding rat tissues (12).

The effects of in vivo oral anticoagulant therapy in man appeared to be mast pronounced on the DTT-dependent reductases in liver. In spite of large interindividual variations, both reductase activities were signiflcantly decreased after 4-hydroxycoumarin treatment. The effects of this treatment on non-hepatic reactions are less pronounced. DTT-dependent $K$ reductases were not inhibited. The ko-reductase activities in the anticoagulant treated group showed a consistent tendency to be lower than those in the non-treated group. Howewer, possibly due to the large interindividual variations, this decrease did not reach the level of significance. The finding that $\mathbb{1 n}$ non-hepatic tissues the ko-reductase activities were less decreased than in liver, is in agreement with data earlier reported for rats $(12,16)$. The 10 -fold increase of rat hepatic endogenous substrate after 4-hydroxycoumarin treatment was not observed in human tissue, while the accumulation of endogenous substrate in non-hepatic tissues was comparably low. In agreement with rat experiments, no remarkable differences were found between acenocoumarol and phenprocoumon treatment. However, the number of tissues investigated was to gmall to be conclusive.

From the data presented, we may conclude that, if oral anticoagulant therapy with 4-hydroxycoumarins affects non-hepatic vitamin K-dependent systems in man, the decrease in reductase actiultes may expected to be small. However, even a small inhibition of the vitanin K-dependent system may lead to an undercarboxylation of Gla-contalning proteins and hence to a loss of biological activity. 


\section{Acknowledgements}

The authors wish to thank the staff of the departments of Pathology from the Slotervate Hospltal in Amsterdam, the University Hospital in Maastricht and the St. Josef Hospital in Kerkrade for supplying us with human tigsues, Drs. H.C. Hemker and H.H.W. Thijssen for their stimulating discussions and Mrs. M. Molenat-v.d. Voort for typing this manuscript. This research was supported by grant MD 82145 from the Trombosestichting Nederland.

\section{REFEREMCES}

1. Sutitie, J.W. Ann. Rev. Biocher. 54:459-477, 1985

2. 0lson, R. E. An.. Rev. Nutr. 4:281-337, 1985

3. Vermeer, C. and de Boer-van den Berg, M.A.G. Haematologia 13: $71-97$, 1985

4. Suttie, J.W. and Preusch, P.C. Haemostasis 16: 193-215, 1986

5. Vermeer, C., Hendrix, H. and Daemen, M. FEBS Lett. 148: $317-320,1982$

6. Buchtal, S.D. and Be11, R.G. Biochemistry 22:1077-1082, 1983

7. De Boer-yan den Berg, M.A.G. and Vermeer, C. Chapter 10

8. De Boer-van den Berg, M.A.G., Verstijnen, C.P.H.J. and Wermeer, C. I. Invest. Dermato1. $87: 377-380,1986$

9. De Boer-van den Berg, M.A.G. and Vermeer, C. Chapter 9

10. Poser, J.W., Esh, F.S., Ling, N.C. and Price, P.A. J. Biol. Chem. 255: $8685-8691,1981$

11. Soute, B.A.M., Miller-Ester1, W., de Boer-van den Berg, M.A.G., U1rich, M. and Vermeer, C. FEBS Lett. 190: 137-141, 1985

12. De Boer-van den Berg, M.A.G., Thijssen, H.H.W. and Vermeer, C. Bitachüm. Blophys. Acta 884: 150-157, 1986

13. De Metz, M., Vermeer, C., Soute, B.A.M. and Henker, H.C. In: Vitamin K metabolism and vitamin K-dependent proteins (Suttle, J.W. ed) $p p$ 560-570, University Park Press, Baltimore, 198.0

1.4. Tishler, M., Freser, L.T., Wendler, N.L. J. Am. Oil Chem. Soc. 62: $2866-2871,1940$

15. Sedmak, J.J. and Grossberg, S.E. Ana1. Blochem. 79: 544-552, 1977

16. ThiJssen, H.H.W., Janssen, C.A.T. and Drttty-Reynders M.J. Blochem. Pharmacol. $35: 3277-3282,1986$ 


\section{SUMMARY AND GENERAL DISCUSSION}

Vitamin $\mathrm{K}$ is involved in the posttranslational carboxylation of specific peptide-bound glutamic acld (Glu) residues to 4-carboxyglutamlc acid (Gla) residues. This reaction is catalyzed by vitamin K-dependent carboxylase, an enzyme which is located at the luminal side of the endoplasmic reticulum. The active cofactor in this carboxylation reaction is the hydroquinone form of vitamin $K$. Witamin $K$ is thought to be absorbed $4 n$ the intestine and transported to the liver $\mathrm{ln}$ lits qulnone forn. In vitro vitamin $K$ quinone may be reduced to witamin $K$ hydroquinone by reductases, one of which is dithiothreitol (DTT)-dependent; the others are NADH-dependent. During carboxylation, vitamin $\mathbb{K}$ hydroquinone $\mathbb{L}$ s converted inta vitamin $\mathrm{K} 2,3$ epoxide which is then reduced again to vitamin $K$ quinone by the DTr-dependent vitamin $K$ epoxide reductase. The physiological counterpart of DTT in these reactions is not yet known. "The DTT-dependent reductases and the vitamin $k$-dependent carboxylase are all present in the microsomal fraction of tissue homogenates. 4-Hydroxycoumarin derivatives such as warfarin, inhibit the DTT-dependent reductases. This results $\mathbb{L}^{\mathrm{n}}$ an exhaustion of the vitamin $K$ hydroquinone supply, and hence the carboxylation rate slows down. In vivo, this sequence of events results in the 
appearance in blood of descarboxycoagulationfactors (PIVKA's), which differ from the normal coagulation factors in such a way that they do not contain the $\mathrm{Ca}^{2+}$ binding Gla-restdues. Hence they have no biological activity. The literature on vitam in $\mathrm{K}$-dependent reactions has been briefly summarized in chapter 1 .

For many years it has been thought that vitamin $\mathrm{K}$-dependent carboxylase occured exclustwely in the liver where it is involved in the formation of the biologically active coagulation factors II, VII, IX and $X$ and the anticoagulant proteins $C$ and $S$. Administration of 4-hydroxycoumarin drugs has been used frequently for the control of blood caagulation during thrombogenlc eplsodes. Nowadays, it is known that vitamin K-dependent carboxylation also accurs in non-hepatic tissues. In this thesis we report the presence of vitarin K-dependent carboxylase activity in several non-hepatic tissues: skin (chapter 2), brain (chapter 3), muscle (chapters 3 and 11 ) and venes (chapter 9). Furthermore we conflrm the presence of vitamln K-dependent carboxylase in kldney, testis, lung, spleen and heart tissue (chapters 3,10 and 11 ) and arterial vessel wall (chapter 9). If expressed per img microsomal protein, the vitamin $K$-dependent carboxylase activities in skin and venes are about $20 \%$ and those in brain and muscle are less than $10 \%$ from that in liver, whle other non-hepatic vitamin $\mathrm{K}$-dependent carboxylase activities ranged between 4 and $30 \%$ from the hepatic activity. Skin tissue from nude mice was separated into epidermal and dermal tissue. In both tissues, vitamin $k$-dependent carboxylase activity was detected (chapter 2 ). The presence of DTT-dependent $k$ reductase and $k$ epoxide reductase in non-hepatic tissues (chapters 2,3 and 11) could also be demonstrated. This Indicates that also non-hepatic tissues contain an enzymatic mechanism to recycle vitamin $k$.

From the present data it cannot be excluded that at least some enzymatic activity, measured in the varlous tissues, originated from the vitain $k$-dependent enzymes present in vessel wall. To overcome the drawback of a mixed population of cells (which is always the case if whole tissue homogentas are used) we have investigated the presence of vitamin K-dependent carboxylase in swall quantities of cultured or isolated cells. For this purpose the carboxylation assay was adapted and using this modifled assay, vitam K-dependent carboxylase activity could be demonstrated in hepatocytes, renal tubular cells, osteoblasts, macrophages, 
endothelial cel1s, smooth muscle cells and in the investigated tumor cells: rat osteosarcoma, human colon carcinoma and mouse melanoma (chapters 8 and 9). In all these cells, reductase activities could also be demonstrated. As compared to the normal cells, the tumor cells showed remarkably low vitamin $K$ epoxide reductase actiwity.

The preparation of a substrate for carboxylase, a bone-Glamprotein which was isolated from bovine bone, is described in chapcer 4. In its decarboxylated form, this protein appeared to be a good substrate for hepatic and non-hepatic witamin $K$-dependent carboxylase. In bovine liver carboxylase, the apparent $\mathrm{K}_{\mathrm{m}}$ for decarboxylated osteocalcin was about 200-fold lower than that for F L E E I.

Another Gla-containing protein was isolated from human spermatozaa: the sperm Gla-protein (chapter 5). The amino actd composition was established and the molecular weight was found to be about 30000 D. After thermal. decarboxylation, this protein also appeared to be a good substrate for carboxylase from various tissues. The function of the sperm-Gla-protein is still unknown.

The results in chapter 6 strongly suggested that vitamin k-dependent carboxylases originating from bovine liver, kidney, lung and testis, may belong to a family of isoenzymes. This conclusion was derived from kinetic studies using 4 different substrates, including decarboxylated osteocalcin and decarboxylated sperm-Gla-protein. From these studies it was clear that the substrate specificities of the varlous carboxylases are different.

It was also investigated if different types of carboxylase mlght occur in one type of tissue. For this purpose we Isolated Erom antlcoagulated bovine liver, carboxylase enzymes bound to prothrombin precursors as well as carboxylase enzymes bound to precursors of factor $x$. The technique of the separation of the two enzyme-substrate complexes is based on the observation that in microsomes from warfarin treated andmals the carboxylase enzyme appeared to be firmly bound to its endogenous substrate. In liver this endogenous substrate 1 s malnly formed by precursors of the coagulation factors $X$ and $I I$. Using Sepharose-linked antibodtes agalnst: native coagulation factor $X$ and prothrombin, the precursor-carboxylase complex could be extracted from the microsomal preparation. The resulting Sepharose-bound carboxylase complexes are designed as SPC-X and SPC-I respectively and both showed carboxylase activity. A number of exogenous 
substrates for carboxylase has been tested but no differences were observed in the apparent $K_{\text {m }}$ values using elther SPC-X or SPC-II. These experiments were hampered by the fact that only sinall substrates could be used. SPC-X and SPC-I are both conplexed to their endogenous substrate Probably because of sterical hindrance, large (protein) substrates are not carboxylated by these enzynes, but exclusively by substrate-free carboxyllase.

In most studies, tissues of animal origin were used. Evidently, the results obtalned with experimental animals should be verified in man. Therefore we have investigated in varlous human tissues, the presence of vitamin $K$-dependent enzymes and some of their properties (chapters 2,9 and 10). In general, the results obtained were comparable with those found in animal studies. If different exogenous substrates were used, the relative carboxylation rates varled, which suggest that also in man the carboxylase from different tissues may differ in their substrate specificlty (chapter 10). In vitro, the DTT-dependent $K$ reductase activities were inhibited by low warfarin concentrations.

The effects of 4-hydroxycoumarin drugs on non-hepatic vitamine K-dependent enzymes have been studied. In rats the effects of a chronic low-dose treatment with three types of 4-hydroxycoumarins (acenocoumarol, pheaprocoumon and warfarin) on hepatic and non-hepatic witamin $\mathrm{K}$-dependent systems were compared (chapter 3). Although the plasma concentrations of the three counarins differed largely, these differences were not reflected In the mictosomal coumarin contents. Non-hepatic microsomes contained per mg protein less than $20 \%$ of the coumarin found in liver microsomes. No substintial differences were observed between the effects of the three anticoagulants. Non-hepatic vitanin $\mathrm{K}$ epoxide reductase activities (kidney, lung, spleen, brain and testis) were between 45 and $65 \%$ of norma 1 , while the hepatic activity was diminished to about $35 \%$ after the in vivo 4-hydroxycoumarin treatments. In liver microsomes, a 15 fold accumulation of non-carboxylated precursor proteins was detected; though less pronounced a simllar effect was found in the non-hepatic microsomes. An increase of the non-carboxylated precursor protelns was also found in dermis and epldermis after warfarin treatment of nude mice (chapter 2). Moreover, if cells were cultured in the presence of warfarin, the amount of endogenous. substrate increased while the reductase activities decreased. 
The in vivo effects of 4-hydroxycoumarin drugs on human vitamin $\mathrm{k}$-dependent systems in liver and in non-hepatic tissues are reported in chapter 11. In this study, large individual variations were observed between the enzymatic activities in corresponding tossues from normal donors. Vitamin k-dependent enzymatic activities were also determined in tissues obtained from donors, who had been treated with 4-hydroxycoumarin drugs for at least 6 months immediately before their decease. In their hepatic microsomes, the $K$ epoxide reductase activity and the DTT-dependent $K$ reductase activity were dimitished to about $35 \%$ and $20 \%$ of the corresponding normal values. The effects of the anticoagulant therapy on non-hepatic reactions were less pronounced. The $K$ epoxlde reductase activities in the anticoagulant treated tissues showed a consistent tendency to be lower than those in the non-treated tissues. However, possibly due to the large interindividual variations, this decrease did not reach the level of significance. No differences were found between the DTT-dependent $k$ reductase activities in the corresponding tissues from normal and anticoagulated donors. In all tissues, the amounts of non-carboxylated precursor proteins were slightly or not increased, whlle no differences were observed in vitamin $K$-dependent carboxylase activities after 4-hydroxycoumarin treatment.

Further research in this fleld will be required to estimate the importance of the effects of 4-hydroxycoumarin drugs on the synthesis of non-hepatic Gla-containing proteins. 



\section{SAMENVATTING}

Vitamin $K$ is betrokken bij de postranslationele carboxylering van specifieke peptide-gebonden glutaminezurresiduen (Glu) tot 4-carboxyglutaminezuurresiduen (Gla). Deze reaktle wordt gekatalyseerd door vitamine K-afhankelijk carboxylase, een enzym dat gelokaliseerd is in the bimnenmembraan van het endoplasmatisch reticulum. De hydroquinon vorm van vitamin $K$ is de aktieve cofaktor in deze carboxyleringsreaktie. Algemeen wordt aangenomen dat vitamin $K$ in quinom vorm wordt geabsorbeerd in de darmen en getransporteerd natr de lever. In vitro kan vitamine $k$ door reductases tot vitamine $K$ hydroquinon gereduceerd worden. Een van deze reductases wordt in vitro door dithiothreitol (DTT) gestimuleerd; de andere worden door NADH gestimuleerd. Tijdens de carboxylering wordt vitamin $K$ hydroquinon ongezet in vitamin $\mathrm{K} 2,3$ epoxide; dit wordt vervolgens door DTT-afhankelijk vitamin $K$ epoxide reductase gereduceerd tot vitamine $K$ quinon. De fysiologische tegenhanger van DTT in genoende reaktie is niet bekend. De DTT-afhankelljke $K$ en $K$ epoxide reductases en de vitanine K-athankelljk carboxylase komen allen voor in de mlcosonale fraktle van weefselhomogenaten. 4-Hydroxycoumarine derlvaten zoals warfarine, remen de DTT-afhankelijke reductases. Deze reming resulteert in een drastisch tekort aan vitamine $K$ hydroquinon en als gevolg daarvan neemt de carboxyleringssnelheid af.

In vivo leidt dit tot het verschijnen van descarboxyfaktoren (PIVKA's) in bloed. Deze efwitten bezitten geen $\mathrm{Ca}^{2+}$-bindende Gla-residuen, zoals de normale stollingsfaktoren hebben. De descarboxystollingsfaktoren hebben dan ook geen blologische aktiviteit. De literatuur betreffende vitamine $\mathrm{K}$-afhankelijke reakties is samengevat $\mathrm{in}$ hoofdstuk 1 . 
Gedurende vele jaren is verondersteld dat de vitamine K-afhankelijke carboxylering ultsuitend plats vindt in de lever. Daar is de reakte noodzakeligk voor de vorming van de biologisch aktieve stollingsfaktoren II, VI, IX en $X$ en de antistollingswituten proteine $C$ en proteine $S$. 4-Hydroxycowmarthe bevatende medicijnen worden weel gebrulkt on ongewenste bloedstolling te vookkmen. Tegenwoordig weten we dat vitamine $k$ afhankelijke carboxylering ook plaatsvindt in niet-hepatsche weefsels. In het in dit proefschrtft beschreven onderzoek stelden we de aanezighedd van witame K-afhankelifiké carboxylase aktivitelt vast in diverse niethepatische weelsels en wel in huid (hoofdstuk 2), in hersenen (hoofdstuk 3), in splerweefsel (hoofdstukken 3 en 11) en in wenen (hoofdstuk 9). Tevens bevestigden we de aanwezigheid van witamine $K$ afhankelijke carboxylase aktiviteit in nier-, testis-, long-, nilt- en hartweefsel (hoofdstukken 3, 10 en 11 ) en in de arteriele vaatwand (hoofdstuk 9). U1tgedrukt per ing microsomal elwit bevatten huid en venen ongeveer $20 \%$ van de hepatische vitamine K-afhankelijke carboxylase-aktiviteit; voor hersenen en spierweefsel is dit percentage minder dan $10 \%$, terwijl deze aktiviteit in andere niet-hepatische weefsels varieerden van 4 tot $30 \%$ van de hepatische enzymaktiviteit. Huidweefsel van nakte muizen werd gescheiden in dermal en eptdermal weefsel. In belde typen weefsel kon vitamine K-afhankelijke carboxylase aktiw1telt aangetoond worden (hoofdstuk 2). In niet-hepatische weefsels werden nast de vitamine k-afhankelijke carboxylase aktivitelt ook DTr-afhanke1ijke $K$ reductase- en $K$ epoxide reductase aktiviteit aangetoond (hoofdstukken 2,3 en 11). Deze resultaten duiden erop, dat ook niethepatische weefsels een enzymatisch mechanisme bevaten dat hergebrulik van Witame $k$ mogeli $1 \mathrm{k}$ makt.

op grond van de huidige gegevens kan niet uitgesloten worden dat wellicht een deel van de enzymatische aktivitelt welke wordt gemeten in diverse weefsels, afkomstig is van de in de vatwand gelokaliseerde whame $K$-afhankelifke enzymen. Wanneer weefselhomogenaten worden gebrukt, is er altifd sprake van een gemengde populatie van cellen. Om dit probleem te amzellen is de aanwezlgheld van vitamine K-afhankelijk carboxylase onderzocht in kleine hoeveelheden gekweekte of geisoleerde cellen. Hiertoe werden de condities waaronder de carboxyleringstest werd uitgevoerd, aangepast. op deze wijze kon vitamine K-afhankelijke carboxylaseaktivitelt aangetoond worden in hepatocyten, niertubulus cellen, osteo- 
blasten, macrofagen, endothealcellen, gladde spiercellen en in de onderzachte tumorcellen: ratte-osteosarcoom-, humaan colon calcinoom- en muize-melanoomcellen (hoofdstuk 8 en 9 ). In alle genoetude cellen werd tevens reductase aktiviteit angetoond. De gemeten $K$ epoxide reductase aktiviteit was in tumorcellen aanzienlijk lager dan in normale cellen. De bereiding van een substrat woor carboxylse, geisoleerd uit runderboten, het Gla-bevattende elwit osteocalcine, is beschreven in hoofdstuk 4. In gedecarboxyleerde vori bleek dit eiwit een goed substrat voor zowel hepatisch als niet-hepatisch wtamine $k$-afhankelijk carboxylase. De gemeten $\mathrm{K}_{\mathrm{m}}$-warde van gedecarboxyleerd osteocalcine voor runderlevercarboxylase was en faktor 200 lager dan de gemeten $K_{m}$ waarden van het synthetisch peptide substraat $F$ L $E \mathbb{E} \mathbb{L}$ woor dit carboxylase.

Een ander Gla-bevattend eiwit werd ut human sperma getsoleerd en aangeduid als sperma-Gla-eiwit (hoofdstuk 5). Hiervan werd de aninozursamenstelling vastgesteld; het molecuulgewlcht werd bepald op ongeveer 30000. Na decarboxylering bleek dit eiwt eweneens een goed substraat voor carboxylase in diverse weefsels. De funktie van het spermaGla-eiwit is niet bekend.

In hoofdstuk 6 stat beschreven dat de carboxylases aanwezig in runderlever, -nier, -long en -testis warschifnlijk isoenzymen zijn. Wit kinetische studies met 4 verschillende substraten, inclusief gedecarboxyleerd osteocalcine en gedecarboxyleerd sperma-Gla-eitit, werd geconcludeerd dat de diverse carboxylases een verschillende substratspecificitelt bezitten. Tevens werd onderzocht of ben type weefgel verschillende typen carboxylases bevat. Hiertoe isoleerden we uit lever vath geantistolde runderen, carboxylase-enzymen gebonden aan precursors van prothrombine, En carboxylase enzymen gebonden an precursors van faktor $x$. De techntek om deze enzyn-substrat complexen te schelden is gebaseerd op de warneming dat, in microsamen van met warfartne behandelde dieren, het carboxylase enzym stevig gebonden zit aan endogeen substrat. In lever bestat dit endogeen substraat voornamelijk uit precursors van de stollingsfaktoren $X$ en II. Door gebruik te maken van de Sepharose-gebonden antistoffen tegen de natleve stolfaktoren $X$ en II, werd het precursor-carboxylase-complex ult de microsomen geëxtraheerd De zo ontstane Sepharose-gebonden carboxylasecomplexen worden angeduid met SPC-X en SPC-II. Beide complexen bezitten carboxylase aktiviteit. Er werden een aantal exogene substraten voor 
carboxylase getest. Er konden echter geen verschilien aagetoond worden in

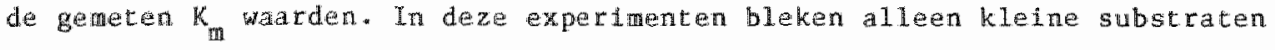
gecarboxyleerd te worden. In SPC-X en SPC-II zijn de carboxylases gecomplexxerd met endogeen substrat. Grotere substraten worden, wellicht door sterlsche hindering, nlet gecarboxyleerd door gecomplexeerde enzymen, maar ultslutend door substraat-vrij carboxylase.

In vrijwel alle studies zijn weefsels wan dierlijke oorsprong gebrulkt. Het zal duidelijk zijn, dat de resultaten verkregen uit dierexperimentele studles geverffleerd dienen te worden in de humane situatie. Om een eerste aanzet hiertoe te geven zijn in verschillende humane weefsels de aanwezlgheld van vitamtne $K$-afhankelljke enzymen en enkele eigenschappen daarvan onderzocht (hoofdstuk 10). In grote lijnen komen de resultaten overeen met de gegevens ult dierexperimentele studies. Wanneer verschillende exogene substraten werden gebrulkt, bleken de relatieve carboxyleringssnelheden te varieren, hetgeen suggereert dat er ook bil j de mens een verschil in substratspecificiteit kan bestaan tussen de verschillende weefselcarboxylases. In vitro werden de DTT-afhankelijke $k$ reductase aktiviteiten gerend door lage warfarine concentraties.

Het effekt van 4-hydraxycoumarlne derivaten op niet-hepatische vitamine K-afhankelijke enzymen werd bestudeerd. In ratten werden de effekten van een week durende behandeling met lage doses 4-hydroxycoumarinen (acenocoumarol, phenprocoumon en warfarine) op hepatische en niet-hepatische vitamine K-afhankelijke enzymen vergeleken (hoofdscuk 3 ). Ofschoon de plasmaconcentraties wan de 3 gebrulkte coumarine derivaten aanzlenlijk verschilden, werden deze verschillen niet teruggevonden in de microsonale coumarine concentrattes. Niet-hepatische microsomen bevaten aan coumarinen per mg eitut minder dan $20 \%$ van de hoeveelheid in levermtcrosomen. Er werden geen essenteèle verschillen in de effekten van de drie anticoagulantia onderilng gezien. Na in vivo behadeling met 4-hydroxycoumarlne waren de vitamine $K$ epoxide reductase aktiviteiten in de niet-hepatische weefsels (nter, long, milt, hersenen en testis) gedaald tot waarden tussen $45 \%$ en $65 \%$ van niet geantstolde controles, terwij1 de aktiviteit in lever was teruggelopen tot ongeveer $35 \%$ van normal. In lever microsomen nam de hoeveelheld niet-gecarboxyleerd precursor eiwit na behandeling met 4-hydroxycoumarines toe met een faktor 15; in de nlet-hepatische weefsels werd eveneens een ophoping van endogeen substraat. 
gevonden, mar deze toename was minder groot. Ook in de dermis en epldermis van nakte muizen werd een verhoogde hoeveelheld niet-gecarboxyleerd precursor eiwit aangetoond nadat deze met warfarine waren behandeld (hoofdstuk 2). Ook wanneer cellen werden gekweekt in aanwezigheid van warfarine, nam de hoeveelheid endogeen substrate toe, terwijl de reductase aktiviteit afnam.

In Hoofdstuk 11 is aandacht besteed aan de in vivo effekten van 4-hydroxycoumarine derivaten op humane vitamine $K$-afhankelijke enzynen in de lever en in niet-hepatische weefsels. In deze studie werden grote individuele verschillen gesignaleerd in enzymatsche aktiviteiten in overeenkomstige weefsels van normale donoren. Vitamine K-afhankelijke enzym aktiviteiten werden ook bepalld in weefsels afkomstig van donoren, die gedurende 6 of meer maanden voorafgaande aan hun overlifden met 4-hydroxycoumarine derivaten waren behandeld. In het leverweefsel van deze donoren waren de $K$ epoxide reductase aktiviteit en de DTT-afhankelijke $K$ reductase aktivitelt gedaald tot ca. $35 \%$, resp. $20 \%$ van de normalwarden. De effekten van antistollingstherapie op niet-hepatische vitanine k-afhanklijke reakties $z i j n$ minder geprononceerd. De $K$ epoxlde reduktase aktivitelt in weefsels van donoren onder antistollingstheraple lijken in het algemeen verlaagd te zijn ten opzichte van de overeenkomstige aktiviteften in normale weefsels. Dit verschil was echter niet significant, hetgeen wellicht een gevolg is van de grote interindividuele spreiding. Er werden geen verschillen gezien tussen normale en geantistolde weefsels in de DTYafhankelijke $K$ reductase aktiviteit, noch in de vitamine $\mathrm{KH}_{2}$ alsankelljke carboxylase aktiviteft. De hoeveelheid endogeen substraat na antistollingsbehandeling was slechts weinig toegenomen.

Verder onderzaek op dit gebied zal nodig zljn on meer inzicht te krijgen in de effekten die 4-hydroxycoumarine derivaten hebben op de synthese van niet-hepatische Gla-bewattende eiwtten. 



\section{Curriculum Vitae}

De auteur van dit proefschrift werd geboren op 7 juli 1950 te Amsterdam. Zij behaalde het diploma gymasium $\beta$ in 1968 aan het Plus $x$ Lyceum te Amsterdam. Daarna trad zij in dienst bij het het centraal Laboratorium van de Bloedtransfusledienst van het Nederlandse Rode Kruis, eveneens in Amsterdam, alwaar zij tot augustus 1974 als analist werkmam was. In de avonduren studeerde $z 1 j$ achtereenvolgens voor het HBO-B diploma biochemie, dat zij in 1971 verkreeg, en voor het Mo-A diploma in de scheien natuurkunde, welke opleiding zij in 1975 met succes afrondde. Daarna studeerde zij aan de Universiteit van Amsterdan en deed het kandidatsexamen in de richting schelkunde in 1976. Het doctaralexamen werd in 1979 afgelegd met als hoofdvak biochemie en als bijvakken neurofysiologie en voedingsleer. Tevens werd een le graads onderwijsbevoegheid in de richting scheikunde behald. In de periode augustus 1974 - juli 1975 en de perlode augustus 1978 - november 1982 was zij als docent scheikunde, natuurkunde, klinische chemie en biochemle werkzaam op diverse scholen in het voortgezet onderwijs en hoger beroepsonderwijs. Vanaf december 1982 tot september 1986 was $z i j$ als wetenschappelijk medewerker verbonden aan de capaciteitsgroep Biochemie van de Rijksuniversiteit Limburg te Mastricht. Momenteel is zlj werkzaam bij de Haagse Hogeschool voor Beroepsonderwijs als docent chemle en als coordinator van de laboratorium-opleidingen in de medisch-chemische richting. 

LIST OF PUBLICATIONS

(Related to this thesis)

M.C. Roncaglionl, B.A.M. Soute, M.A.G. de Boer-van den Berg, C. Wermeer. Warfarin-induced accumulation of vitamin $K$-dependent proteins. Comparison between hepatic and non-hepatic tissues. Biochem. Biophys. Res. Commun. 114 (1983) $991-997$

M.A.G. de Boer-van den Berg, C. Vermeer. Vitamin K-dependent carboxylase. Prac. Int. Soc. Haematol., European and African Division (Barcelona, Sept. $4-9,1983$ ) Abstr. 122

M.A.G. de Boer-van den Berg, M.C. Roncaglioni, B.A.M. Soute, M. de Metz, C. Vermeer. Oral anticoagulants: unexpected side-effects or new flelds of application? In: "Haemostatic Fallure in Liver Disease", Eds. P. Fundu and o. Thys. Martinus Nijhof Publishers, Boston, USA. 1984, p $24-35$.

C. Vermeer, B.A.M. Soute, H. Hendrix, M.A.G. de Boer-van den Berg. Decarboxylated bone Gila-protein as a substrate for hepatic vitanin K-dependent carboxylase. FEBS Lett. 165 (1984) 16-20.

B.A.M. Soute, M.A.G. de Boer-van den Berg, C. Vermeer. The separation of bovine prothrombin and descarboxyprothrombin by HPLC. Anal. Blochem. 137 (1984) $227-229$

C. Vermeer, B.A.M. Soute, M. Ulrich, K. Hamulyák, M.A.G. de Boer-van den Berg. The vitamin K-dependent carboxylation of proteins. Biochem. Soc. Transactions. 12 (1984) 922-924

C. Vermeer, M.A.G. de Boer-van den Berg. Vitamin K-dependent carboxylase. Haematologia 18 (1985) $71-97$.

M.M.W. Ulrich, M.A.G. de Boer-van den Berg, B.A.M. Soute, C. Vermeer. Iso-enzymes of vitandn K-dependent carboxylase. Blochim. Blophys. Acta 830 (1.985) $1.05-108$

K. Hamulyăk, M.A.G. de Boer-van den Berg, H.H.W. Thijssien, C. Vermeer. The placental transport of $\left[{ }^{3} \mathrm{H}\right] \mathrm{vitamin} \mathrm{K}$ in rats. Thrombos. Haemostas. 54 (1985) 150

B.A.M. Soute, W. Muller-Esterl, M.A.G. de Boer, M.M.W. Ulrich, G. Wermeer. Discovery of a 4-carboxyglutamlc acid-containing proteln in human spermatozoa. FEBS Lett. 190 (1985) 137-141

M.A.G. de Boer-van den Berg, B.A.M. Soute, M.M.W. Ulrtch, H.C. Hemer, C. Vermeer. Vitamin $K$-dependent carboxylase: the carboxylation of exogenous substrates in different systems. Biochlm. Biophys. Acta 831 (1985) 94-98

M.C. Roncaglioni, M.M.W. Ulrtch, A.D. Muller, B.A.M. Soute, M.A.G. de Boer-van den Berg, C. Vermeer. The vitamin K-antagonism of salicylate and warfarin. Thromb. Res. 42 (1986) 727-736 
M.A.G. de Boer-wan den Berg, C.P.M.J. Verstijnen, C. Vermeer. Vitamin K-dependent carboxylase in skin. J. Invest. Dermatol. 87 (1986) 377-380

K. Hamulyák, M.A.G de Boer-van den Berg, H.H.W. Thijssen, H.C. Hemker, C. vermeer. The placental transport of [ $[$ ] Haematol. 65 (1987) in the press

M.A.G. de Boer-wan den Berg, H.H.W. Thijssen, C. Vermeer. The in vivo effects of acenocoumarol, phenprocoumon and warfarin on vitamin $K$ dependent carboxylase in watlous tissues of the rat. Biochim. Biophys. Acta, 884 (1.986) $150-1.57$

M.A.G. de Boer-wan den Berg, L.J.M. van Haarlem, C. Vermeer. Vitanin K-dependent carboxylase in human vessel wall. Thrombos. Res. Suppl. VI (1986) 134

M.A.G. de Boer-van den Berg, H.H.W. Thljssen, C. Vermeer. The in vivo effects of acenocoumarol, phenprocoumon and warfarin or vitamin Ko-reductase and vitamin $K$-dependent carboxylase activities in hepatic and non-hepatic tissues of the rat. Thrombos. Res. Suppl. VI (1986) 165

M.A.G. de Boer-van den Berg, M.P. Uitendaal, C. Vermeer. Direct measurement of vithamin $K$-dependent enzymes in varlous isolated and cultured tumor and non-tumor cells. Mol. Cell. Biochem. (1987) in the press

M.A.G. de Boer-van den Berg, L.J.M. van Haarlem, C. Vermeer. Vitamin Ktdependent enzymes in cultured cells from human arterial and venous vessel wall. Submitted for publication

M.A.G. de Boer-wan den Berg, C. Vermeer. Some characteristics of vitamin K-dependent carboxylase in human tissues. Submitted for publication

M.A.G. de Boer-van den Berg, C. Vermeer. The in vivo effects of 4-hydroxycoumarin derivatives on human hepatic and non-hepatic vitamin k-dependent enzymes. Subnitted for publication 